\title{
A DEVELOPMENT STRATEGY AND ACTION PLAN FOR "AFGHAN FRUIT GROWERS"
}

\author{
Prepared for:
}

Afghan Development Association. Pakistan

\section{VOLUME 3: APPENDICES 1 - 8}

Prepared by:

\section{E. Vernon}

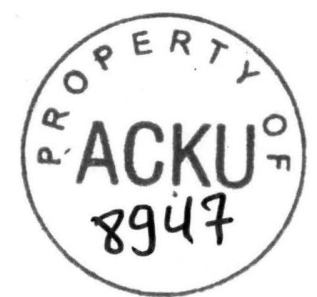

High Value Horticulture Limited,

1 St. Giles, Oxford. UK

April 2000 
VOLUME 3

Appendix 1 Terms of reference

Appendix 2 Example of how different fruit varieties can be used to extend the supply season

Appendix 3 Gender integrated approach to group formalization and enterprise development

Appendix 4 Improving the Access of Smallholders to Agricultural Services in Sub-Saharan Africa: Farmer Co-operation and the Role of the Donor Community

Appendix 5 A brief guide to minimize microbial food safety hazards for fresh fruits and vegetables

Appendix 6 Sample costs to establish an almond orchard and produce almonds, Northern San Joaquin Valley - Flood Irrigation

Appendix $7 \quad$ New grape production systems

Appendix 8 Production practices and sample costs for growing organic grapes 
Appendix 1

Terms of reference 


\section{Appendix 1}

\section{Terms of Reference \\ for the \\ Processing \& Marketing Consultancy}

\section{Objective}

To review production, post harvest handling and marketing channels for produce from Afghanistan, with the overall objective to identify constraints of the existing system and product opportunities. To outline a development strategy and action plan based on a short list of selected crops, products and markets.

\section{Study}

1. Conduct a rapid audit of production, post harvest and processing practices and identify:

a) improvements to the practices, and

b) diversification opportunities utilising novel processing procedures through appropriate technology transfer.

2. Conduct a rapid audit of the market systems for the domestic, regional and international markets, identifying constraints and future strategies.

3. Assess the current product range and highlight opportunities and constraints in the development of new products.

4. On the basis of the above:

a) Prepare a shortlist of target products and markets.

b) Prepare a strategy and action plan for an integrated approach to addressing the constraints.

c) Identify needs for further technical assistance and marketing support.

It is proposed that programme will be for 22 person days over a 2 month period. The person days will include 16 days +2 days travel be undertaken in country with the remainder being report write up and international customer contacts. 


\section{Appendix 2}

Example of how different fruit varieties can be used to extend the supply season 
QUALITY FRUIT MARKETING

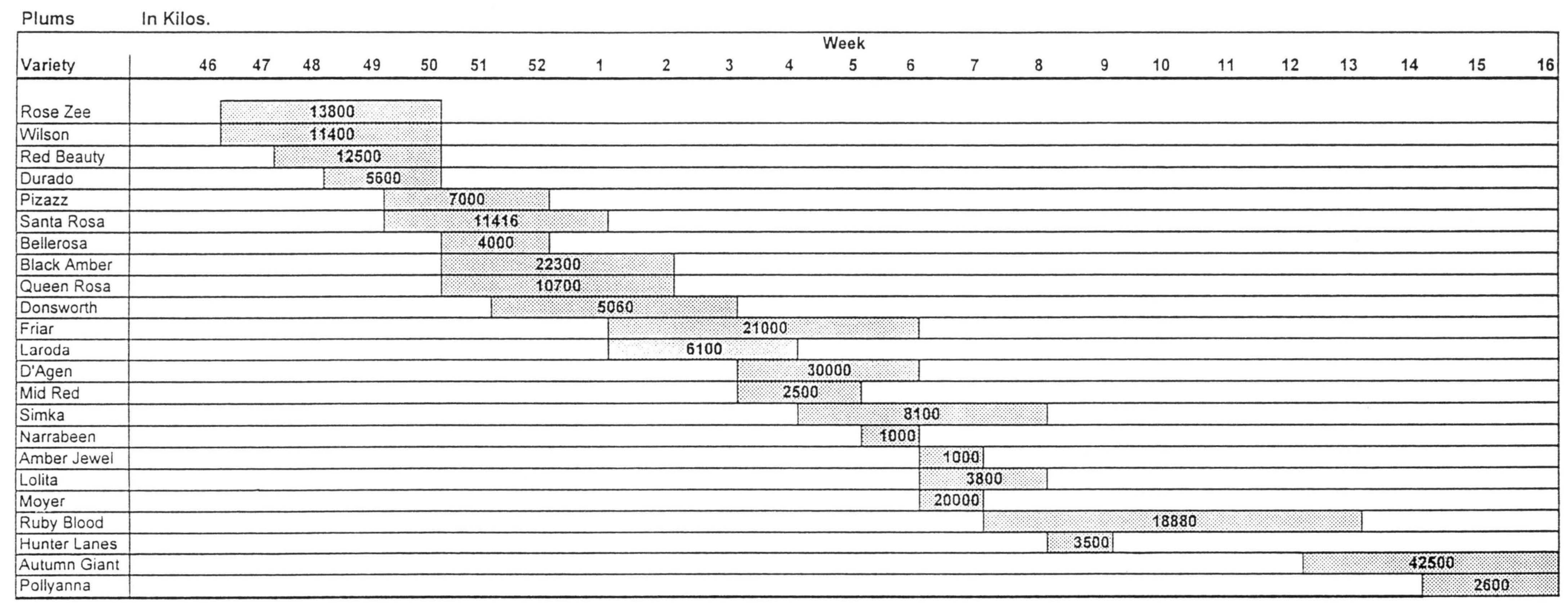




\section{QUALITY FRUIT MARKETING}

Nectarines In Kilos.

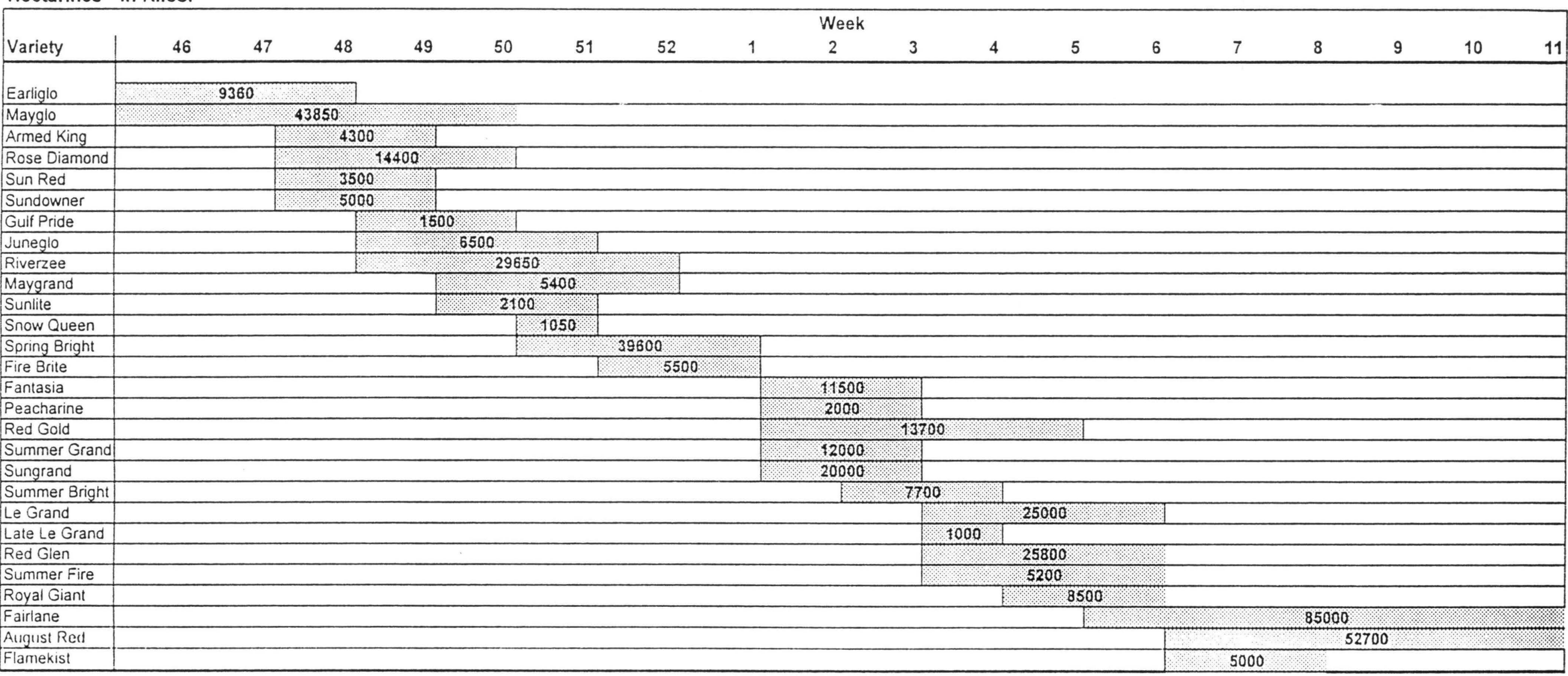


QUALITY FRUIT MARKETING

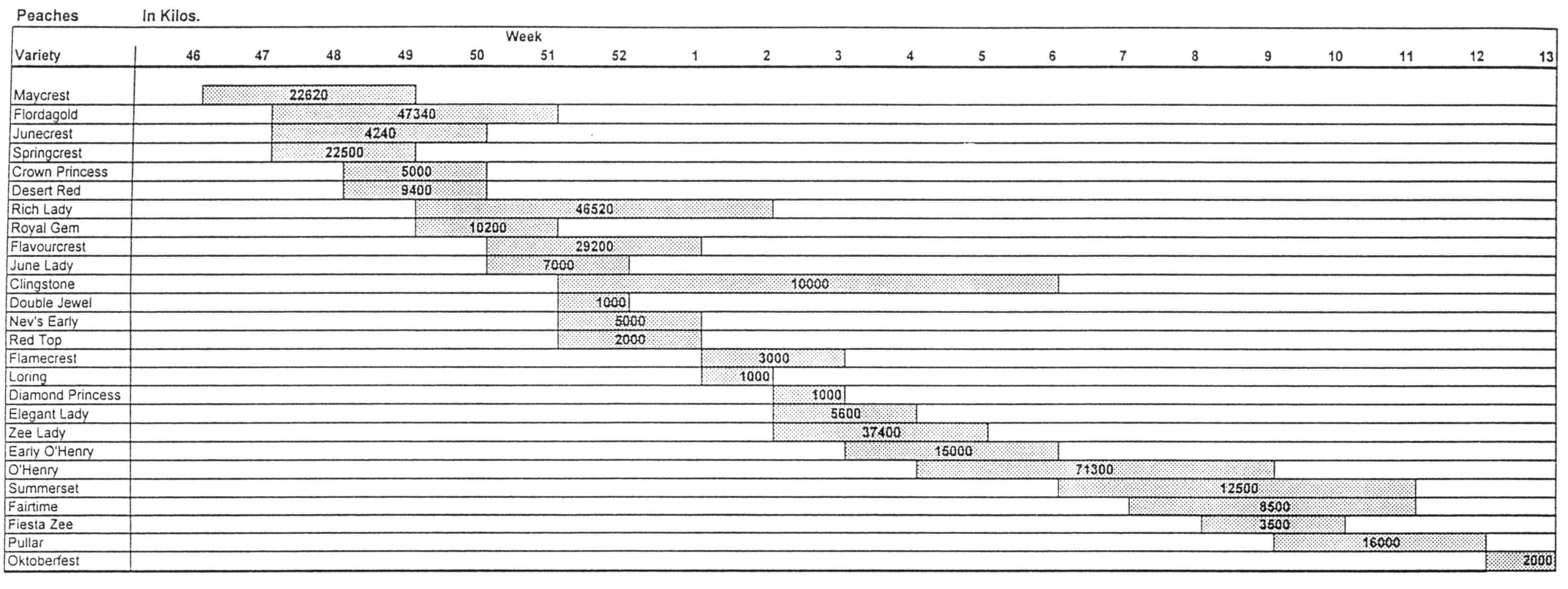


QUALITY FRUIT MARKETING

Apricots In Kilos.

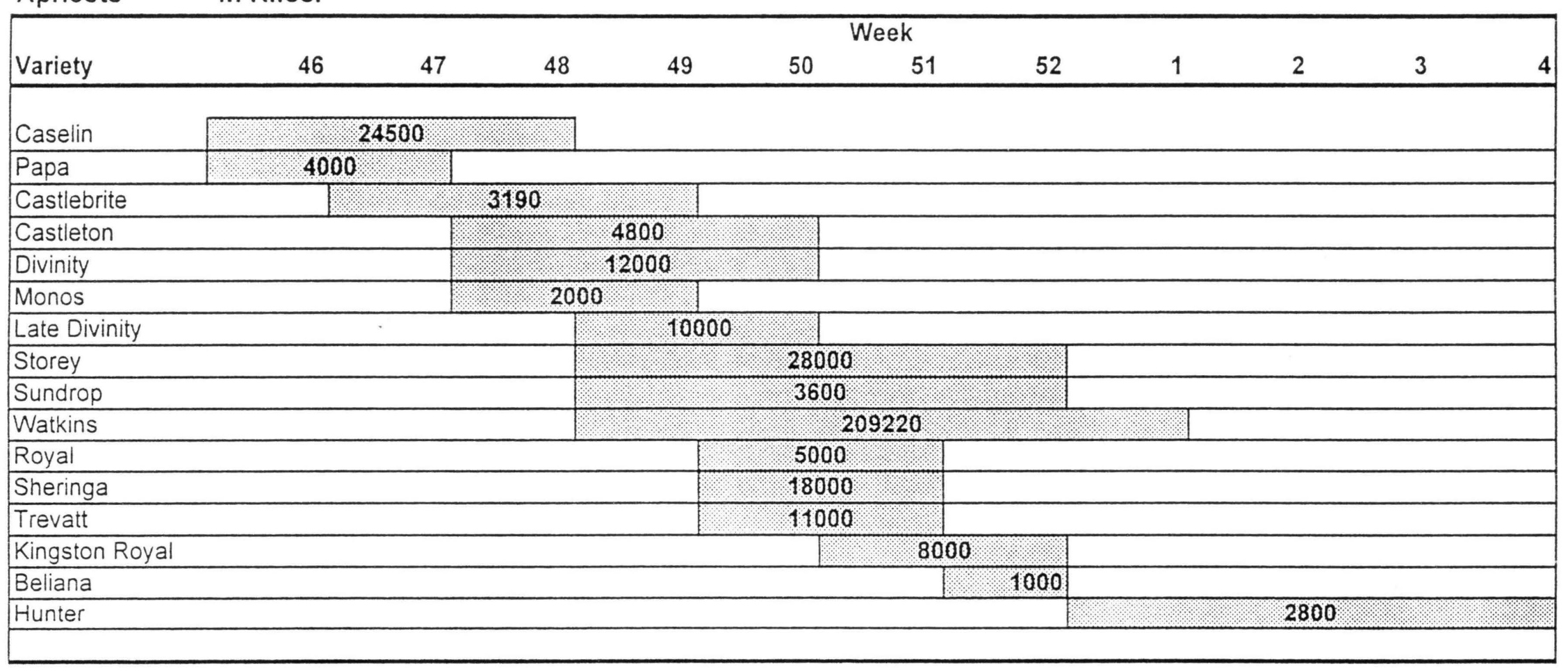




\section{Appendix 3}

Gender integrated approach to group formalization and enterprise development 


\title{
Group \& Infrastructure Development
}

\section{An Integrated Programme}

\author{
The HPU Approach \\ November 1999
}




\title{
Group \& Infrastructure Development
}

\section{An Integrated Programme}

\author{
The HPU Approach
}

November 1999 


\section{Group \& Infrastructure \\ Development Programme}

- Strength and success lies in unity.

- United we stand, divided we can be $J$ J H exploited.

Ahmad Qayum G\&ID Officer.
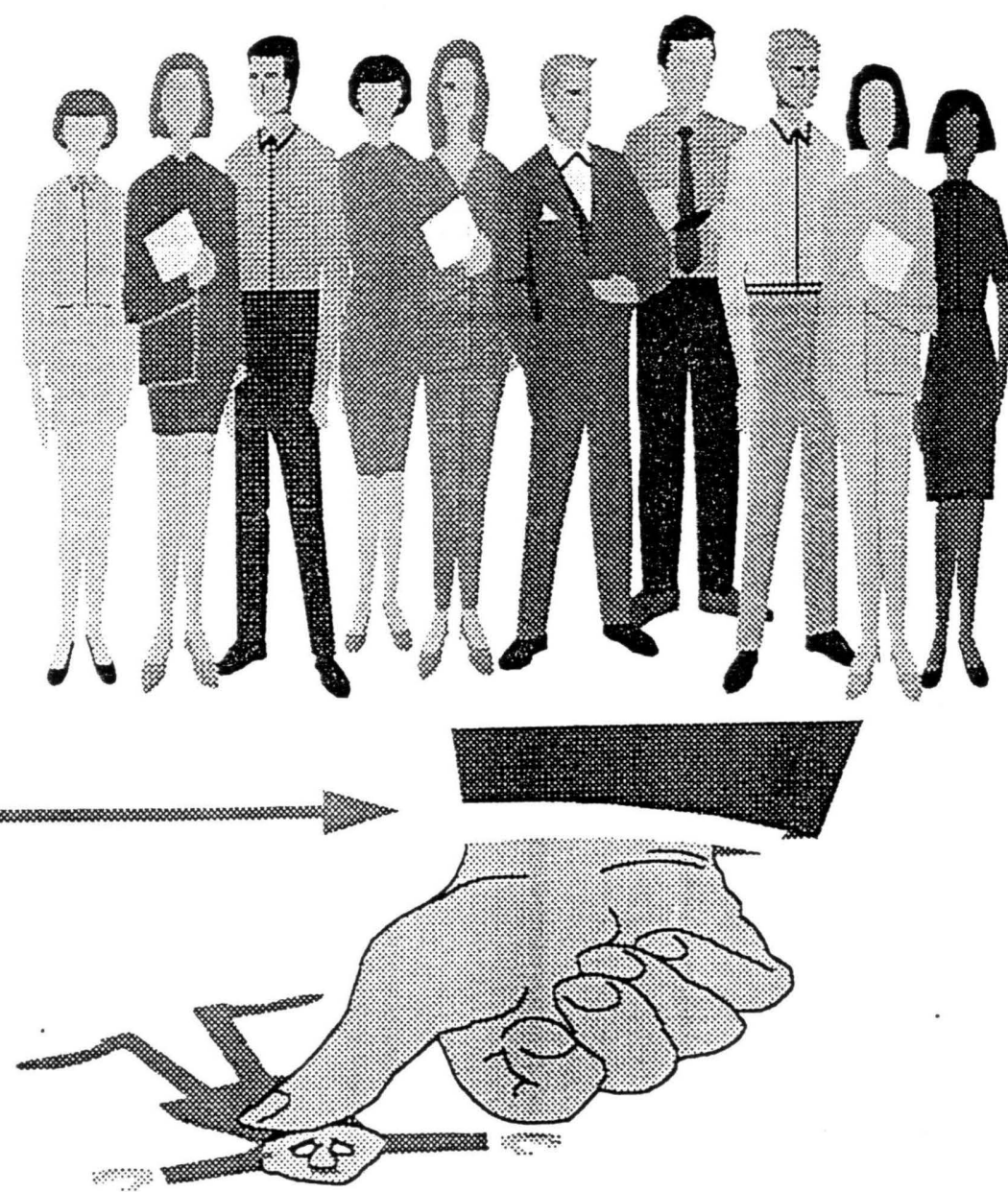


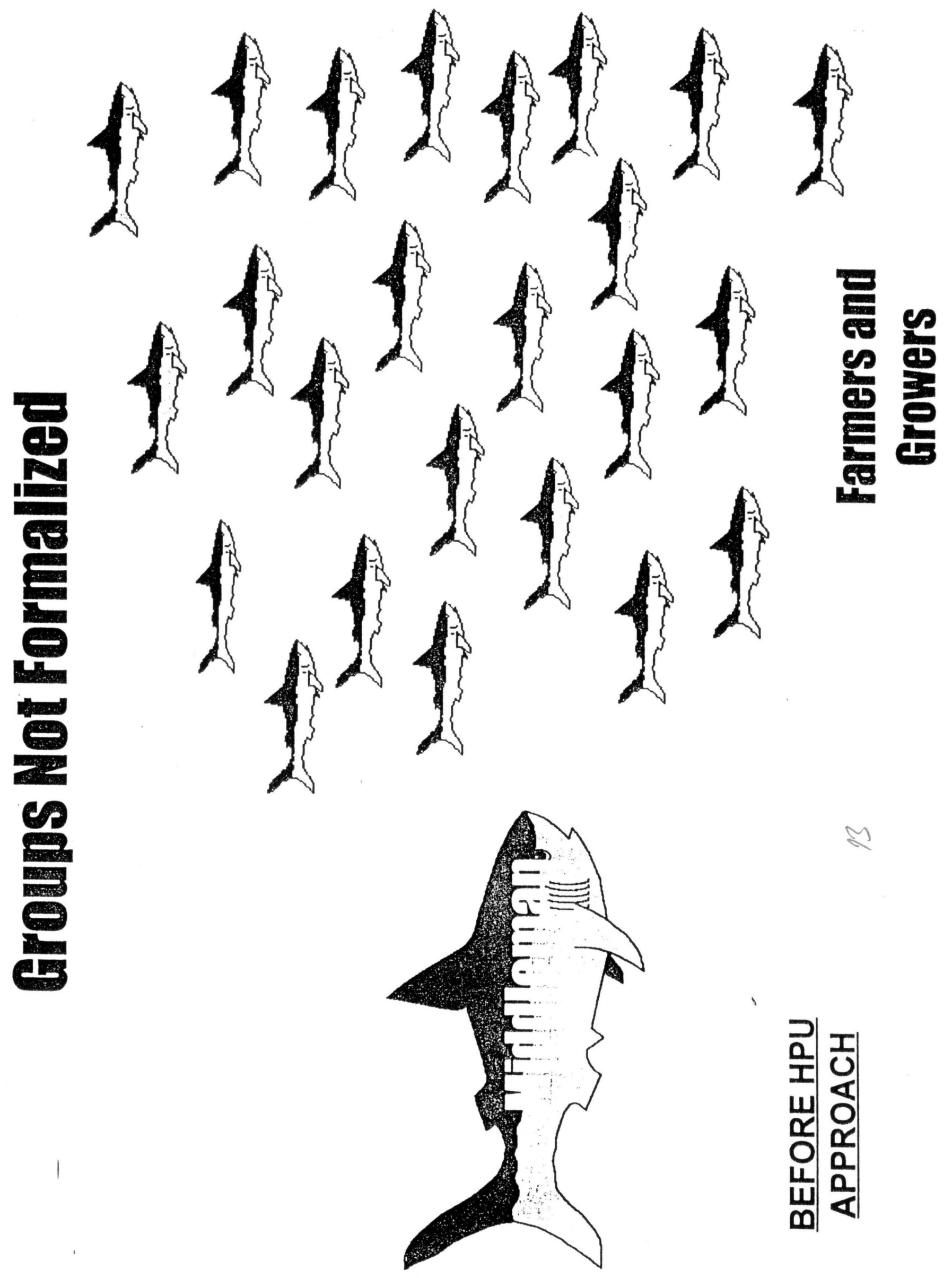



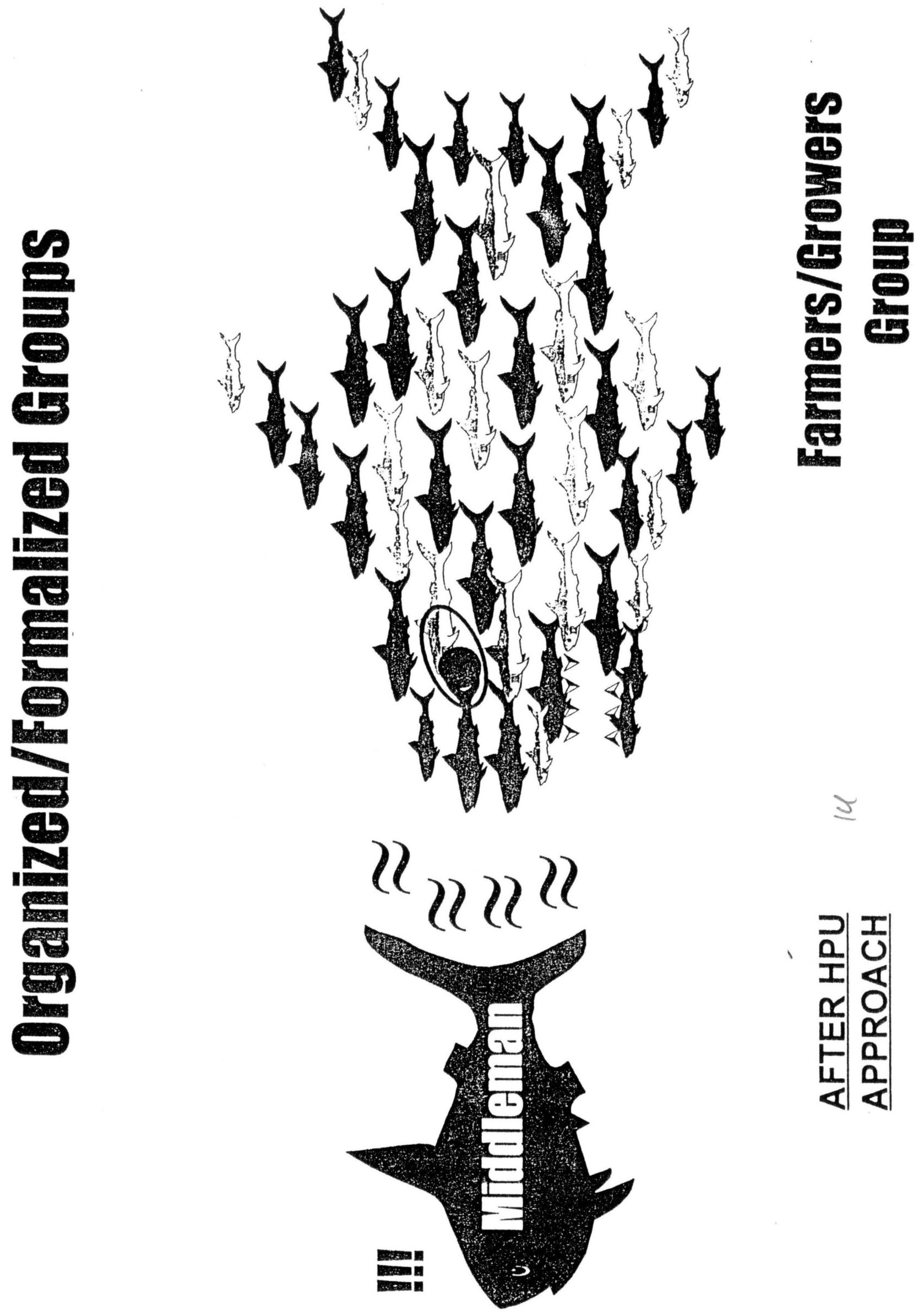


\section{HPU's \\ Gender Integrated Approach to Group Formalization \\ and \\ Enterprise Development Programme}

Farmers and rural women both play an integral and important role in the horticultural sector, although the latter's role has been neglected or has not been taken into much consideration. The diversity and complexity of rural livelihood mean that efforts to alleviate poverty in rural areas will have to be multi-faceted and holistic, taking into consideration existing social norms and customs. For example, since many of the poorest are landless, and cannot be reached through traditional agricultural interventions, other methods of assessing their needs and supporting them in a demand-led process of development must be found.

For rural women formal employment opportunities are extremely limited. Women's employment in the informal sector can only be found in agro-based and offfarm activities. Various studies have identified several constraints for rural women in generating income-earning opportunities. Foremost among these obstacles is the fact that training programmes are often not related to market needs, nor has the right marketing approach been taken into consideration. Hence prospects and sustainability of income-generating activities (IGAs) for women are either limited or defeated in the long run.

The task of identifying and serving the needs of rural people in general, and the poor who are ill-served by markets in particular, remains daunting. HPU's approach is to seek more responsive institutional structures through decentralization and to form partnerships or develop linkages/ networking with organizations (NGOs/CBOs etc.) that have a better record of success in target areas at grassroots level. To facilitate effective and sustainable transfer of technology, and also keeping in view the new policy of SDC aimed at civil society, decentralisation, poverty alleviation, human rights and sustainability, HPU has now adopted an integrated gender approach, focussing on the horticulture sector, targeting male and female groups already formed by other projects.

Since NGOs have a dense network of organized rural groups, extension services and training strategies, they are considered an important vehicle for reaching and developing sustainable community organizations (COs) at grassroots level. Once these COs are well-established and functional, the NGOs and projects (like PHP) can gradually withdraw its support.

HPU's Group and Infrastructure Development Programme was incorporated for the first time in the Yearly Plan of Operation (YPO) for 1999-2000. To make the programme cost effective, efficient and sustainable, HPU is now working directly with groups rather than with individual farmers, which was the earlier strategy. In some areas, HPU have identified and formed their own farmer/grower groups. These groups, with their collective access to institutional credit, provide the mechanism by which current dependence, by the small farmer on tied market-credit, can be broken.

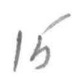


Realizing the need to support women's income-generating/saving activities, the Enterprise Development Programme in the WID sector was launched in mid-August 1999. It's objective is to promote and sustain women's horticulture-related microenterprise, in concert with partner Institutions of PHP. Although in its nascent stages, this programme of HPU has already made headway in building up linkages with credible organizations/projects in different regions of NWFP.

Through these organizations, women target groups, active in horticulture-related IGAs are identified. Surveys are already being carried out through staff \& group meetings and by means of a Training Needs Assessment questionnaire; the activities are closely linked with those of the Group and Infrastructure Development Programme

Once the women's needs are assessed and the specific IGAs are identified, the training programmes will be designed in consultation with the HPU team and resource persons, taking into account the local social norms and customs regarding "purdah". Not only will skills training and transfer of technology be facilitated for these women, but their activities will be bolstered by training in quality control, appropriate packaging and marketing techniques as well. In certain situations where the support of the women's men-folk are lacking, awareness-raising campaigns will also be carried out. 
WID Enterprise, Group \& Infrastructure Development - The HPU Approach

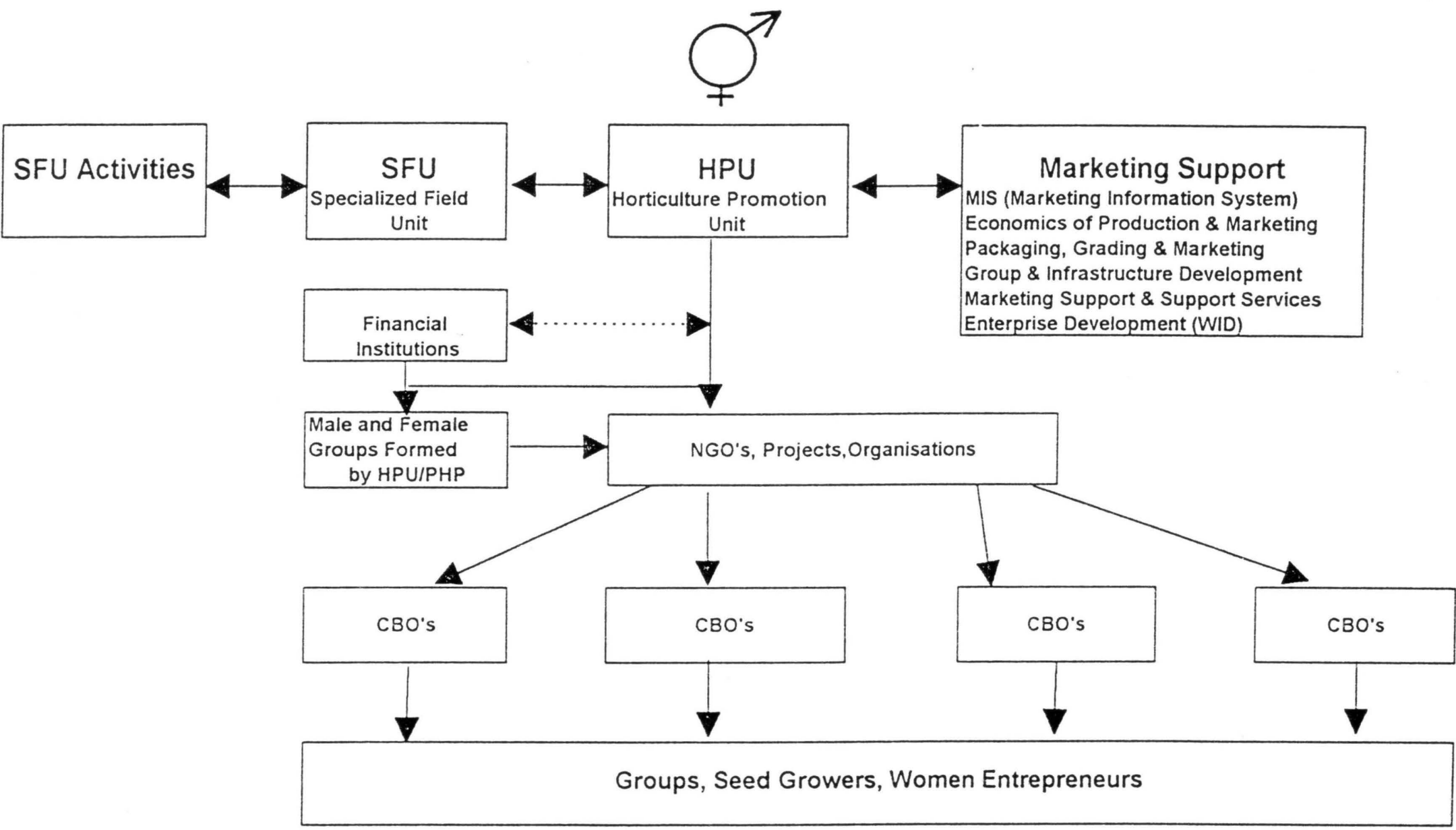




\section{Group and Infrastructure Development}

\section{Main Objectives :-}

1. Organise and formalize groups of (farmers, growers and women entrepreneurs) in horticulture sector and develop linkages with the private sector. Ultimate objective is for the groups is to become an institution (an independent and self-reliant, self-sustaining body).

2. Identify groups already formed by other organisations, projects and NGO's in order to disseminate and facilitate the transfer of horticulture technology in an efficient and cost-effective manner, without duplication of activities.

3. त Facilitate access to credit for these poor farmers/growers/women entrepreneurs. V

4. Develop linkages with financial institutions who provide credit.

5. Raise awareness of self-saving schemes, providing training on credit operations, management of enterprises, group management, record keeping etc.

6. Arranging training for groups formalized by HPU/PHP in order to develop their technical skills in horticulture crops production and marketing. 


\section{CRITERIA FOR ORGANIZING MEN/WOMEN'S GROUPS:}

1. All the men/women involved in an income-generating project should belong to the same village. This will facilitate communication (to have weekly meeings) and harmonious relationship. A small area of operation also facilitate expedient and grass-root level interaction with the administrative machinery of the Government.

2. The members should have the same socio-economic background, this will facilitate an easier working atmosphere. A group having diverse interests would be beset by problems from its very inception.

3. The size of the group should be small, preferably from 15 to 25 members. The smaller the group, the closer would be the personal contact between the members so they are likely to take greater interest in the affairs of the group. In the case of large groups, there is a tendency for some members to become indifferent. This can have adverse effect on the more interested members of the group and consequently the project suffers.

4. For successful working of the group, an energetic, knowledgeable, motivated and honest leader is of paramount importance. It must be ensured that the right person is elected as leader of the group. The role of the leaders is crucial as the responsibility for beneficial interaction with the concerned govt./financial institute rests on them Similarly, sustaining the interest of the members of the groups and ensuring equitable benefits to the members are major tasks of the leader.

5. In any group activity, the willingness to help and the active support of the local concerned Govt. functionaries must be ensured. Even if the local functionaries are believed to be indifferent and disinterested in the affairs of the groups, a hostile attitude towards them would be counter-productive as it is quite possible that their indifference may be due to cultural factors, ignorance, lack of motivation or just plain lethargy which is so common among them. The group must also learn and understand the limits of the govt. functionaries, financial institutions, etc.. what can and cannot be done under existing conditions.

6. Women's groups, in particular, should avoid confrontation with the male members of the local community. In a male-dominated society, such a confrontation can have adverse consequences for the projects/programmes for women's welfare. On the cther hand, if the goodwill and support of male members are secured, spectacular results can be achieved.

7. Formation of groups for income-generating activities can be facilitated in villages where a number of group are already active in other activities

8. The group should ensure accountability. In view of the circumstances prevailing in the country, this factor has assumed greater importance. It may be stressed that financial propriety does not only mean that development outlays are used for the approved purposes and according to item-wise allocations in cost-effective ways. This is an issue of creating public awareness of development priorities and ensuring financial discipline in the implementation of projects and programmes. Closer supervision, monitoring, coordination and training could generate respect for accountability and lessen the possibilities of gross violations of public trust. 
9. The group member should not close relatives such as brothers, sisters, father; mother, uncles etc.

10. The group should know each other very well, and should previously have been involved in economic transactions with each other.

11. The group member should be willing to make sacrifies for each other.

12. The members should provide a guarantee for each other, If they require credit from the banks or other financial institutions. 


\section{Advantages of Group Formation}

\section{Importance and advantages of group formation :}

1. Provides experience and facilitates information sharing and networking.

2. Provides access to resources.

3. Time/resource-saving for development projects.

4. Needs assessment becomes easier.

5. Promotes skill development.

6. Facilitates interaction with government, donors, etc.

7. Accessibility problem is reduced.

8. Facilitates sharing of responsibility for capital cost.

\section{Why groups?}

1. Dissemination of technology is easy.

2. Awareness of self-saving is possible.

3. Formation of group fulfills the requirement of financial institutions for credit, if required by the group members.

4. Problem of a single member is the problem of the entire group.

5. Strength of 10 members in a group is equivalent to one big landowner.

6. Collective selling and buying is one major advantage of group formation, e.g. one member, nominated by the group members, can buy inputs, seed, fertilizers, insecticide etc. and another member can sell the produce of the group (in an efficient and cost-effective manner).

7. Cost of transportation is shared by the group.

8. They can bypass the middleman and sell their produce directly to wholesale markets.

9. Groups can have a collective storage place.

Sustainability will depend upon:

- Training/skills development.

- Access to resources.

- Monitoring and follow-up.

- Accountability of members to the group as an organization.

- Revolving funds which should be generated by the group.

Post-training support to groups for sustainability:

- Refresher courses.

- Linkages with Development Finance Institutions (DFIs), etc.

- Identification of and solution to post-training problems. 


\section{Group Formation}

An elected executive committee :-

Members of the executive committee will be formed by a process of election from the general body members of the group/association.

The executive committee will comprises of :-

(a) President

(b) vice-president

(c) General Secretary

(d) Joint Secretary

(e) Finance Secretary

(f) Press Secretary

The executive committee office bearers are appointed/elected by the group members for a specific job, specific time period.

The executive committee approves and appoints the working members.

Duties and functions of the executive committee office bearers.

\section{(1) President :-}

Qualities :- A person responsible to all members, have some educational background and having managerial and administrative characteristics.

- Presides the meeting of the general body and executive committee.

- Will call off either meeting in case of incomplete quorum.

- Be able and incharge of solving disputes of group members.

- Will distribute work amongst office bearers.

- Will sign bank cheques, with the finance secretary.

- Assist general secretary in preparation of agenda for meetings.

- Will sign agreement for the association with other parties.

- Create association linkages with other organisation. 


\section{(2) Vice-president :-}

- Will carry out duties of the president in his absence.

- Vice-president should have some managerial and administrative characteristics.

\section{(3) General Secretary :-}

- Will prepare and distribute agenda for executive committee and general I body meetings.

- Will keep record of proceeding of executive committee and general body meetings.

- Will prepare annual work plan and annual reports of the association activities.

- Will manage group/association office.

\section{(4) Joint Secretary :-}

- Will perform obligations in the absence of general secretary, and will have the same authorities as general secretary.

\section{(5) Finance Secretary :-}

- Will keep records of the organisation accounts.

- Will submit the account for income and expenses at the meeting of managing committees.

- Will assist auditors in fulfilling their duties.

- $\quad$ will deposit receive money in bank in organisation account.

- Will have the duty to collect saving money from the group/association.

\section{(6) Press Secretary :-}

- Propaganda the aims, objectives and the program of the organisation.

- $\quad$ And he will use different ways for propagation. 
Incharge Rural Development Programme.

Micro Business \& Rural Developmenl Depll.

Dale: $12 / 083 / 99$

Bank of Khyber,

24 - The Mall,

Peshawar Canll.

Subject: $\quad$ Credit Provision to an organized group of Small farmers in the Tangi irost-free area of district Cliarsadda

Horlicullural Promolion Unit (IPU) is a component of Project for Horlicullunal Promolion

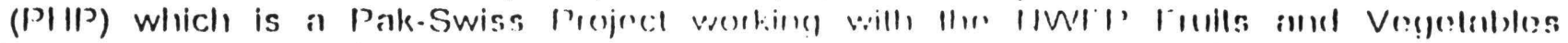
Development Board (FVDB). PIP aims al povenly allevialion lluough suslaimalsle development activities with the small lamers in the lield of horliculture. IIPU, under the same objective of PHP. is working to improve the minkeling of horlicullual cosps 10 increase the income of small larmers

One of the programmes of HPU, is credil and group development in horticultural producers. Through this activity we have formed an organizalion of len small farmers in village of Tangi (Disll. Charsadda) named Mansoor Abad. Tomalo being a major crop of this area, is aboul to be grown. The larmers organized by us need an immediale linancial assislance for inpuls, land preparation and water charges lor this lomalo crop). An estimaled annomint of Rs. 35,000/-is needed by some members of the group)

You are requested to consider of sanclioning a loan under you micro-credil prognamme lo llis organized group of lamers in langi area lor oll.season lomalo produclion. We,

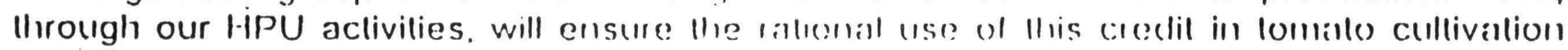
and will monilor the repayment of loan in lime

Allached please find delails of the group lomed by lhe ('III)

Yours truly,

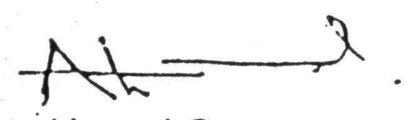

Ahmad Qayum

Credil \& Group Development Coordinalor

cc: Mr. Syeed Khan Orak(yzai. MNI) FVIn

Mr. J.E.Cuoper, Adviser I:V(.)'.'lll'

Mr. Amjid Ali, Regional Markelung ()llceer (Cenllall Re(g)

Mr. Tahir Ali Shah, Markeling Orficer 


\section{Group Development Training and Group Formation}

Venue :- Mansoorabad (Tangi), Districl Charsadda.

Dale :- 31/07/99

Participants:- List allached.

A meeting was organised among the vegelable growers of Mansoor Abad and allended by PHP slaff. The purpose of llis meeting was lo give linining to llie farmers on group) formation and its advantages the growers of this area are very hard working and produce off-season tomato and cucumber in ivinler season

A majorily of the growers have prolessionial knowledfye and have been fullier liained by the PIP lechnical slall on secdling produclion. lomalo, cucumber and onion production.

The growers' main source of income is the above-mentioned vegetables, which lliey sell in the local Tangi markel.

Alter considerable brainstoming and having iennlified llin socio-economic conditions and problems of the growers. Hey were lacilitaled and molivated lowards group) development organisation. Afler a delail discussion. Ho famers angeed to fom a gloup) called "Farmers Development Sociely" and Hereby elected Iheir management commiltee (Execulive Body)

These are: Gul Hussain (Presidenl)

Awal Khan (Vice Presiclenl)

Pir Syed Ali Shah (General Secrelary)

Zain Ullah Khan (Joint Secrelary)

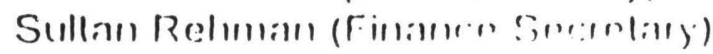

Credil from the bank:

The procedure of gelling loan from lhe bank :.as discussed in delail will llie famers. The lamers agreed will the procechre and asked lor a loan of Rs.35,000 (llinly-live thousand only) for lhe group to produce oll-season lomaloes and cucumber. 


\section{Social Economic Conditions of the Group}

Group Name:-

Location :-

Number of house holds (families) :-

Existing/previous type of organisation :-

Ethnic :-

Main income sources for the group :-

Farm size :-

Main crops :- Horticulture -

Marketing/Sale :-

Specialised persons in group : No.

Subject :

Linkages with Govt/Projects/NGO's :-

Credit taken by the groups :

Credit taken in the form of :

With interest or with out Interest:

Repayment Conditions and time period:

Any major changes during last year :

Future planning :

Problems:-

- Non availability of quality tomatoes seed.

- Pesticide/Fertilizers adulteration.

- Less availability of irrigation water.

- No formal source/availability of credit.

- No proper information about seed dealers.

- Pest/disease problems of vegetables.

Any other Please speciíy :- 


\section{Social Economic Conditions of the Group}

Group Name:- Famers Developmenl Suciely (Mansoorabad Tangi Charsadda)

Location :- Mansoorabad (Tangi) Districl Chaısadda

Number of households (families) :- 10 (population 130)

Existing/previous type of organisalion - Inlormal jirya

Links with olher NGO's/Elhnic :- Ulmankhel

Aim income sources for the group :- Faming (oll-season lomalo and cucumber)

Farm size :- $2 \quad 1 / 2$ acres to 30 acres

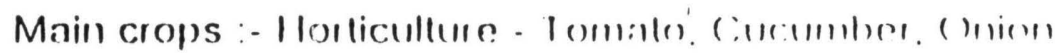

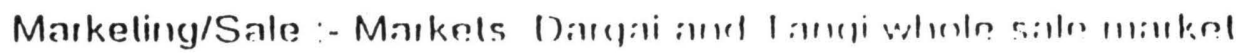
Marketing Chanmels Inderidual lammons

Number of trained persons in group : $10110 \mathrm{~s}$

Specialized Subjecls: Tomalo and Cucumber produclion and seedling production.

Linkages wilh GovUProjecls/NGO's - in

Credit taken by the groups: From Commission a(̣nnts in ()ançai and Tangi mankel.

Sources: In lhe form of cash \& inpuls ( $\because$ ill houl prolitimleresl)

Repayment Conditions and lime period (ln the fom of poldue and cash) time period When the (rop) is sold in the markel.

Any major changes during last year scholl ofl-seasen vegelables production which broughl changes in line lile slandard.

Fulure planning: Cilus (Sweel oranges) orchards

Problems:-

- Non-availability of quality lomato seeds

- Pesticide/Fertilizers adulleration

- Less availability of irriçation water

- No formal source/availability ol credil

- No proper information aboul seed dealers

- Pesvdisease problems of ve(jolables 


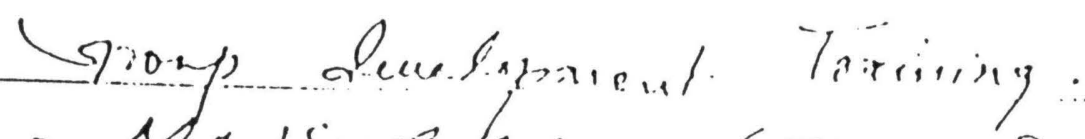

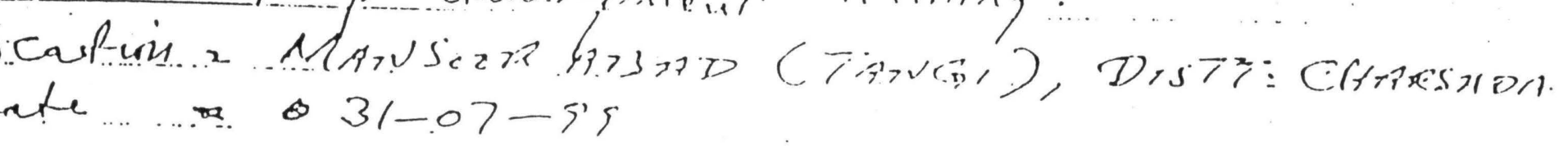

Alame Asmar than.

Arral than. Gall gruarin.

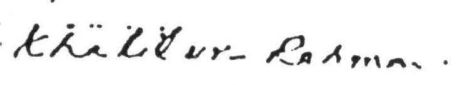

Risionalla s.

Arkdioss. Sis

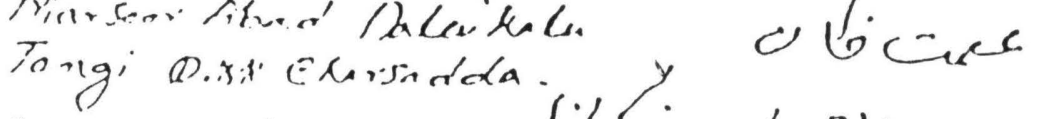

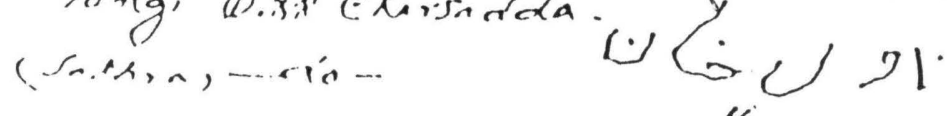

tretian bexmon

Zainullatu.

Niarnet Slak.

Dir. Syed sici slah.

0
$\cdots$
$\cdots$

…tis

-retio

Javed Hrogain.

$-r^{\prime}$

1. Huray Zab

inyad apei

abistitighel.

-...ing-

beat., 9royus.

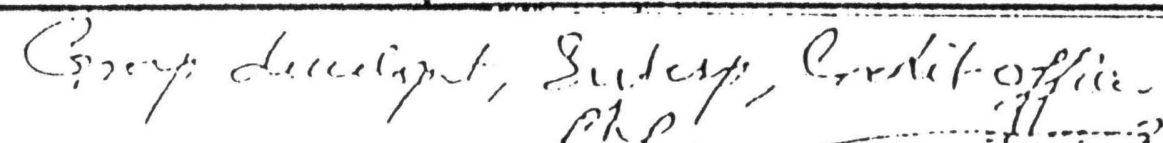

php! =

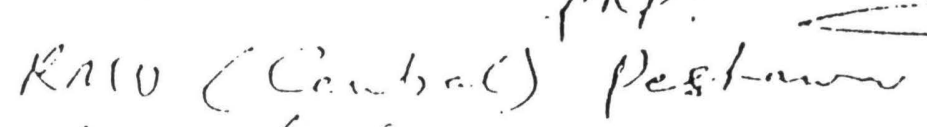

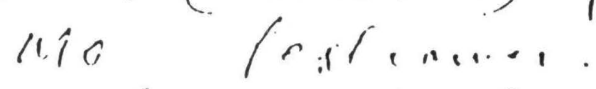

pite, l'osider.

28 


\section{The Bank of Khyber}

Head Office : 24, The Mall, Peshawar. Tolephone: 279289, 273456, 273587 Fax : 278146

$$
\operatorname{Fax} 845572
$$

Mr Ahmed Qayyum

Monitoring \& Evaluation Coordinator

Project for Horticulture Promotion.

Subject:

TAE BANK OF KAYBER

This refers to our tele-conversation on date regarding collaboration of BoK with PHP in the development activities.

The BoK initiated its Rural Development Program in Aug , 1997 for provision of Rural Micro Financial Services in the province of NWFP. The key feature of this Program is establishment of linkages through facilitators with the community based organizations in the rural areas.

We would welcome PHP facilitation in development of these linkages with its communities/groups, keeping in mind the social maturity of the groups as demonstrated earlier to BoK at Timergara \& Charsadda where BoK has already sanctioned loans for horticulture promotion.

We are looking forward to a mutually beneficial relationship for interventions in various regions leading to the economic growth of the Province.

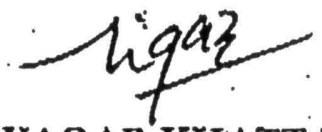

WAQAR KHATTAK

ASSISTANT DIRECTOR

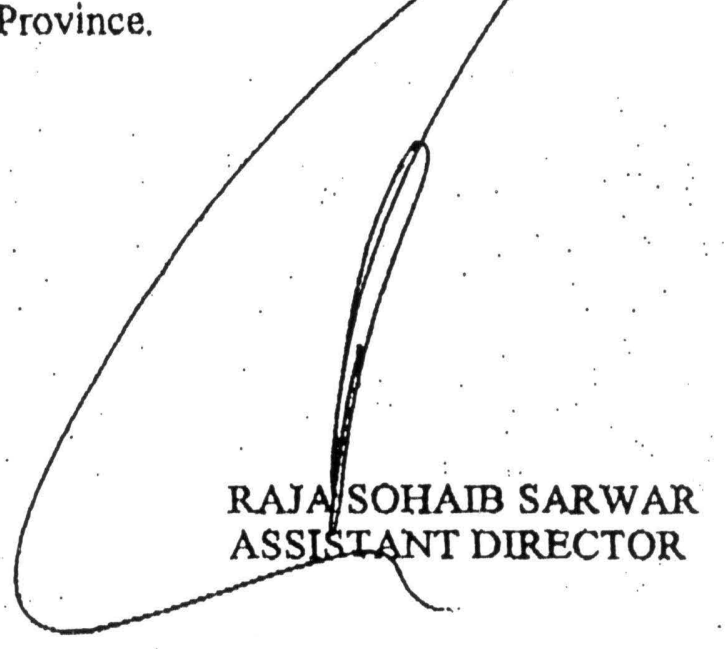




\section{Criteria for Loaning by Bank of Khyber (BoK)}

In order to promole income generating activities including on-farm agriculture and micro enterprises in the rural communities, organized and supported by ProjecUNGO following is agreed:

\section{Role of various partners:}

A) Role of communities.

- Assume the primary responsibility of the Credit Programme along with BoK.

- Develop and operate a responsible social organization.

- To establish sustainable saving schemes.

- To carry out socially needed activities.

- TO assess their credit needs and priorities.

- Provide collateral $10 \%$ of loans from their collective savings.

- Provide assurance to BoK for repayment of loans

B) Role of Bank of Khyber

- Provide necessary credit orientation to social organiser, credit officer and village activist.

- The landing will for new and existing micro enterprises and agriculture inputs/development loans.

- The loans would be upto 50,000 for individual member of the group and Rs. $2,50,000 /$ for the whole group.

- Processing and sanctioning procedure for loans upto 50,000 has been simplified.

- BoK will provide $2 \%$ from the mark up received to the leaders of community organization for their support to the Bank

C) Role of facilitator

- Primary role of NGO/Project would be to act as facilitalor between community and Bank of Khyber.

- Link up organised and socially mature communities with BoK.

- Provide assistance to BoK in evaluating social malurity of each group.

- Assist the communities in assessing their credit needs and formalizing credit requests for processing by BoK.

- Grass-root awareness and mobilization of the community.

\section{Group Lending Procedure}

Group loan application will be submilted by the president/village aclivist to the BoK (Project Orficer or Bank Manager) and will be supported by

1. Loan resolution by the community

2. Business plans for individuals

3. Letter of recommendation by the NGO

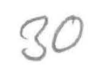




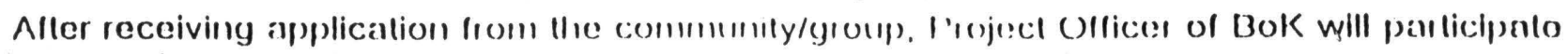
the meeting called by the Project stalf and check for the following:

- Social maturity level of the group.

- Savings, aggregate and plans.

- Business potential of individual numbers

- Repayment period and size of instalment etc.

- Saving account of the group with BoK

\section{Post Sanction Requirements:}

- Guarantee forms and stamps.

- Opening of PLS account. 


\section{THE BANK OF KHYBER}

Micro Business S: Rural Development Deplt

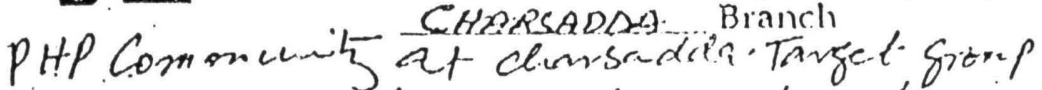

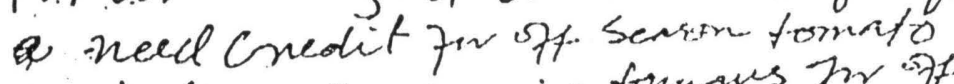

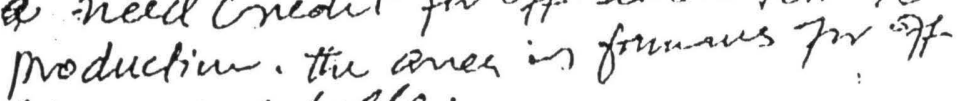

jeagon wegctusle PROPOSAL FOR GROLIP LOAN

Ule MA BAT ALi sHAtt-Eroup.

Nembers of Mansoor Abad community/(group) have proposed for group lom through local credit appraisal including the representatives of the Bank of Khyber,

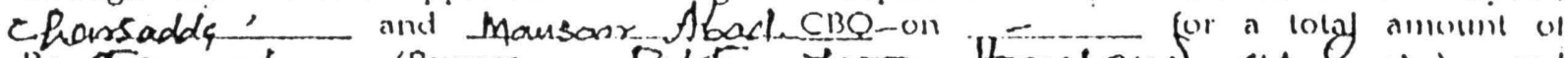

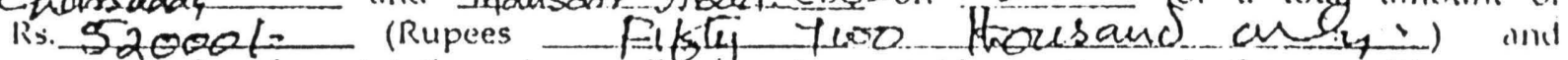
group members have jointly and severally as reed to provide sureties and other securities as fuer ruril development program.

The community/(group) has prioritized their needs as follow's:

Names of Loances

1) KHALIL UR= REHMAN

2) ZAM ULLAH.

3) AWLAL KHAN

2) SULTAN UR-RLItimar

S) TAVED KHAN

6. MOHAM AD NAZIR

2) SAID ALI SHAH
P'urpose

Fertifizer For Tomato for crop.
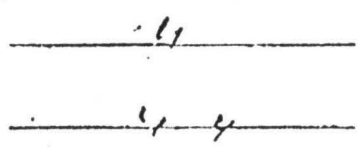

1111

$1<4$

lotill Rs
Requested Proposed Repaynient modto Amount Amomint nind period
$6000 \%=6000 \%=15$

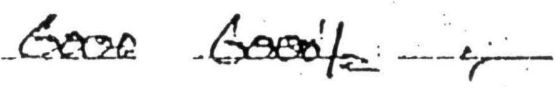

$9000 k$ gook - -

1,0000\% $9000 \mathrm{~d} \cdot \mathrm{-1}$

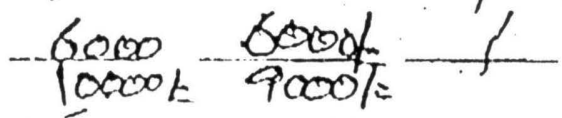

$=52000 \mathrm{~L}=5000 \mathrm{q}$

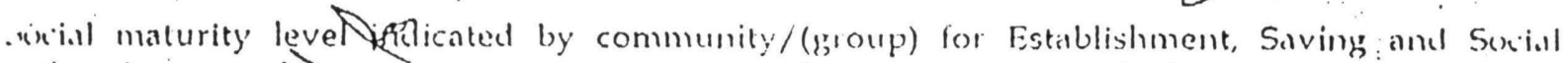
. Nitinns is issesyshas

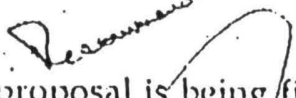

The proposal is being/finclized after scrutiny of relevant documents and field appraisal for group lu, in of Rs and sumitted to Departmental Committe for approval with Whervations/recomplendation to.
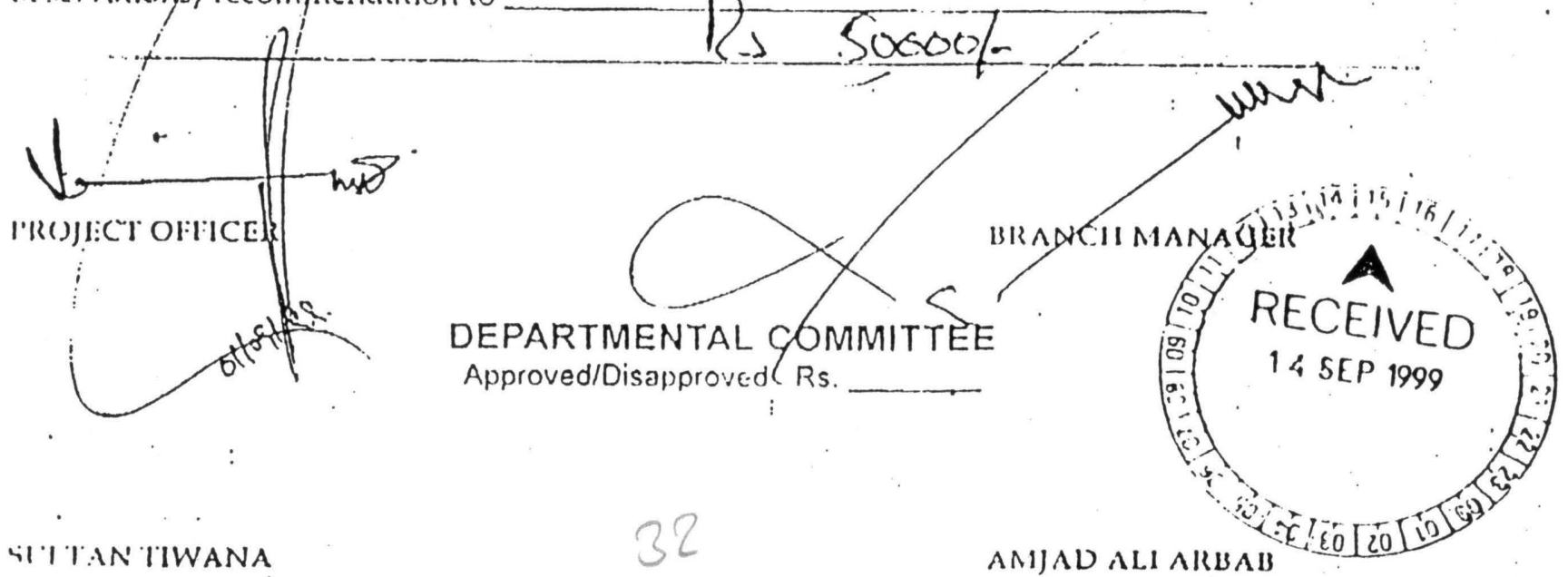


\section{PROJECT For HORTICULTURAL PROMOTION

\section{October 4, 1999}

Mr. Mian Majeedullah

NRSP-ADC

Mardan

Subject: Training Programme for Farmers Association in Mansoorabad, Tangi. Charsadda Mr. Majeedullah,

Please refer to our letter dated August 13, 1999 (copy attached) regarding PHP's request to NRSP to carry out a training programme for one of our farmers group in Mansoorabad, Tangi. This was one of the main topics discussed during the meeting in the PHP office on August 12.

To date we have not received any intimation from your part concerning the above training programme, no doubt due to your workload. However, we feel the urgency for this training as the farmers group has recently been granted a loan by the Bank of Khyber.

We also acknowledge receiving the list of WUAs and WOs which NRSP has identified for HPU intervention (sent vide letter dtd August 21/99, No. 726/99/RPO/Mdn). Please excuse the delay in acknowledging this letter since we were busy with the External Evaluation of PHP, which concluded only recently. We will inform you of our plans to visit these WUAsNOs in the near future.

We also look forward to receiving from you the details/schedule of the training programme for our larmors group.

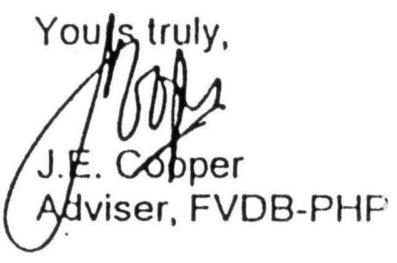

cc: Ahmad Qayum, Credit \& Group Development Officer, HPU

Amina M. Amin, Enterprise Officer (WID), HPU

Tahir Ali Shah, Marketing Officer, HPU

Amjad Ali, Regional Mktg. Officer, HPU 


\section{TRAINING NEEDS ASSESSMENT}

1. Name of Group:

2. Location:

Registered:

3. Name of Member:

4. Civil Status: Single Married Widow

5. What is your highest education background? Primary Secondary Intermediate Matric None

6. Number of members in your family? Adults Children Dependents

7. What is your family's main source of income? How much

8. What income-generating activity (IGA) are you doing and since when?

\begin{tabular}{|l|l|l|}
\hline \multicolumn{1}{|c|}{ ACTIVITY } & SINCE & INCOMENYAR \\
\hline A. & & \\
\hline B. & & \\
\hline C. & & \\
\hline D. & & \\
\hline
\end{tabular}

9. How did you get the skills for this IG activity? __ Self-taught formal/informal training

10. If formal training, who did the training and where?

11. Where is your source of raw material for the above IGA?
A.
B.
C.
D.

12. Where do you market your goods?

13. Are you helped by husband/sons/other male members? No _ Yes. If yes, how? 
14. What problems, if any, do you face with your IGA?

\begin{tabular}{|l|l|}
\hline Packaging/packing & $\begin{array}{l}\text { Basic business management and simple } \\
\text { bookkeeping }\end{array}$ \\
\hline Labeling & Maintaining Quality \\
\hline $\begin{array}{l}\text { More capital needed to buy equipment/ } \\
\text { machine, etc. }\end{array}$ & $\begin{array}{l}\text { No access to credit through: } \\
\text { banks } \\
\text { other sources }\end{array}$ \\
\hline Marketing & More training \\
\hline Sourcing Raw Materials/Inputs & Others: Specify \\
\hline
\end{tabular}

15. Do you have control of your money? No _ Yes. If yes, how do you spend the money?

16. Are you able to save? No Yes. If yes, where? Group savings; Bank Home

17. Do you intend to start any horticultural IGA? Yes No. If yes, specify.

\begin{tabular}{|l|}
\hline A. \\
\hline B. \\
\hline C. \\
\hline D. \\
\hline
\end{tabular}

18. Are you willing to get skills training for this? Yes No.

19. Aside from the above, what other skills training in horticulture are you interested in?

\begin{tabular}{|l|l|}
\hline Seed production & Handling of pesticides \\
\hline Fruits drying & Processing of jams, jellies, juices \\
\hline Vegetables drying & Grading and packaging \\
\hline Nursery fruit tree-raising (which fruits/trees) & Mushroom raising \\
\hline Kitchen gardening & Spices \\
\hline Other & \\
\hline
\end{tabular}

20. How will this horticulture IGA benefit you and your family?

21. In case of inobility, will there be a problem for you to attend training classes? Yes No. Near the home Outside your area/village Different city (i.e. Peshawar) 
22. Will you be allowed to attend training classes for a number of days ( 2 - 7 days)

23. Who will manage your home \& household duties during the training?

Note: This training needs assessment will enable the trainer to glean the following information:

1. Education background and aptitude of the respondent to learn new skills which will allow trainer to design appropriate, practical and applicable training sessions.

2. Family and economic situation which will help to determine the credit needs.

3. Respondent's specific training needs enabling trainers to dispense with unnecessary topics during the training programme.

4. Mobility and training duration limitations, enabling HPU to schedule training programmes within a certain time frame, with due attention paid to location and logistics for the trainees' benefit.

5. Problems being encountered by the respondent with her IGA, thus enabling HPU trainers to focus on it.

6. Type of support extended by the family, specifically the male members, which will indicate the extent of their cooperation and their awareness of development programmes and benefits of promoting women's IGAs. Without men's support, women's programmes often fail.

7. Necessity of linking-up women entrepreneurs with financial institutions and other credit facilities by HPU.

8. Assess the socio-economic impact of the micro-enterprise on the women and their families. 
No. of Respondents: 38 women

\begin{tabular}{|l|c|}
\hline \multicolumn{1}{|c|}{ Areas/Villages: } & $\begin{array}{c}\text { \# of } \\
\text { Respondents }\end{array}$ \\
\hline Serai Payan & 6 \\
\hline Ooch & 6 \\
\hline Timergara & 6 \\
\hline Talash (Kalpani Ziarat) & 8 \\
\hline Begum Dara & 6 \\
\hline Talash (Kandaro) & 6 \\
\hline
\end{tabular}

Civil Status: $S=21 ; \quad M=14 ; \quad W=2 ; \quad D=1$

Education:

Resp.

\begin{tabular}{|l|c|}
\hline Primary & 8 \\
\hline Secondary & 4 \\
\hline Intermediate & 8 \\
\hline Matric & 13 \\
\hline BA & 1 \\
\hline None & 4 \\
\hline
\end{tabular}

Source of Family Income:

Resp.

\begin{tabular}{|l|c|}
\hline Agric./Service & 9 \\
\hline Agriculture & 8 \\
\hline Service/Private (GoP, laborer, driver etc.) & 16 \\
\hline Business & 3 \\
\hline Husbands abroad & 2 \\
\hline
\end{tabular}

Family Income/Month:

\begin{tabular}{|c|c|}
\hline Income Range (Rs.) & Resp. \\
\hline ㅁ 16,000 & 1 \\
\hline ㅁ 10,000 & 6 \\
\hline ㅁ 8,000 & 3 \\
\hline ㅁ $5,000-6,000$ & 2 \\
\hline
\end{tabular}




\begin{tabular}{|c|c|}
\hline Income Range (Rs.) & Resp. \\
\hline a $3,000-4,000$ & 16 \\
\hline a $1,000-2,000$ & 9 \\
\hline a No response & 1 \\
\hline \multicolumn{2}{r}{} \\
\cline { 1 - 2 }
\end{tabular}

No. of women in service $=13$

\begin{tabular}{|c|c|}
\hline Range of Income/Month (Rs.) & \# of Resp. \\
\hline ㅁ, 5,000 & 1 (LHW/Trainer) \\
\hline 무 3,000 & 1 (Teacher) \\
\hline ㅁ $2,000-2,200$ & 3 \\
\hline ㅁ $1,000-1,500$ & 7 \\
\hline ㅁ 500 & 1 \\
\hline
\end{tabular}

No. of women involved in the following IGAs:

\begin{tabular}{|c|c|c|}
\hline Activity & \# of Resp. & Income Range (Rs.) \\
\hline 1. Beekeeping & 6 & $\begin{array}{l}5,000=1 \\
2,500=2 \\
2,000=2 \\
1,000=1\end{array}$ \\
\hline 2. Handicraft & 9 & $\begin{array}{c}1,000-1,200=2 \\
600-800=3 \\
500=4\end{array}$ \\
\hline 3. Handicraft/Beekeeping & 2 & $1,000=2$ \\
\hline 4. Other & 5 & $500-1,000=5$ \\
\hline Total & 22 & \\
\hline
\end{tabular}

All 38 respondents are interested in starting Horticulture-related IGAs, mainly food processing/ preservation/drying.

Other Training Interests (in order of preference):

\begin{tabular}{|l|c|}
\hline \multicolumn{2}{l|}{ Resp. } \\
\hline 2. Fruit Tree Nursery Raising & 37 \\
\hline 3. Fruit Processing (jams/jellies/juices) & 32 \\
\hline 4. Kitchen Gardening & 32 \\
\hline 5. Grading/Packaging & 31 \\
\hline 6. Mushroom raising & 31 \\
\hline 7. Spices & 28 \\
\hline 8. Pesticide Handing & 21 \\
\hline
\end{tabular}




\section{Assessment/Comments:}

1. All 38 women respondents have their male members' support in whatever training or IGA they are engaged in.

2. All 38 respondents require training in marketing alongwith technical skills training for the chosen IGA.

3. Skills development and marketing training must be carried out in Dir (preferably through the LFA's of the FVDB' Women's Programme based in Dir.

4. In this case, since strict "purdah" is being observed in Dir, it is recommended that LFAs of the FVDB (WP) stationed in Timergara, Dir carry out the skills training for the women. In addition these same LFAs will have to be trained in marketing/packaging, and refresher courses (specially in quality control) be arranged for them through PHP.

5. It is also recommended that male members of the group be given an awareness training in marketing, specially those engaged in agriculture.

Note: The Gen. Secretary of DITSWC has said that they will try to acquire funds from DASP to cover the training costs (inc. stationery, materials/equipment, mobilization of women, refreshments, honoraria for the resource person/s etc.). I have already spoken to him about the confirmation and commitment from DASP in writing and to give us a copy. 


\section{Questionnaire for Farmers/Women Group/Association in Horticulture Sector}

(1) Name of the Group/Association

(2) Group/Association Leader

(3) No. of Members in Group/Association Ethnic Group:

(4) Group/Association Activity

(5) Number of members in the Group/Association who are:

(a) Land Owner

(b) Tenant

(c) Total Farming Area

(d) Average farm size per member

(6) What crops do you produce? Vegetable Crop ( ) Fruit Crop ( ) Cereal Crop ( )

(7) Vegetable Crops

Fruit Crops

Cereal Crops

Others

(1)

(2)

(3)

(4) (1)

(2)

(3)

(4)
(1)

(2)

(3)

(4)

(4)

Average income:

(8) Problems with the activity:

$>$ Non-availability of quality tomato seeds

$>$ Pesticide/Fertilizers adulteration

$>$ Less availability of irrigation water

$>$ No formal source or access to credit

$>$ No proper information about seed dealers

$>$ Pest/disease problems of vegetables

Any other please specify 
(9) Location of Group/Association working area:

(10) Supported by, facilitating agency or Associated with (NGO, CBO, Bank, etc.) Please give details:

(11) Letter of recommendation by the supporting agency, i.e. (organizational capability).

(12) Registered with (Name, Address Telephone/Fax of the Organization)

(13) Registration No.

(14) Operational Since

(15) Social Organizer (SO) (Name and Address)

(16) Prospect/Justification report by the Social Organizer/Tehsildar/Govt.Representative (attach, if any)

(17) Objectives of the Group/Association. (Please attach copy of the Constitution, if any)

(18) How many trained workers does the Group/Association have . In what field?

(19) Who provided the Training and which Facilities were used?

(20) If none, would they require training Yes ( ) No. ( ) What type

(21) How often does the Group/Association hold meetings (weekly, monthly, quarterly, six monthly or yearly or when required).

(22) Is the management in Group/Association. elected by the general body Yes ( ) No ( ).

(23) Is the Group/Association useful for the members Yes ( ) No ( ).

If yes, in what sense 
(24) Do the members sell the whole of their produce through the Group/Association?

Yes ( ) No. ( ). If Yes a: Collectively ( ), b: Individually ( )

If No. Please state reasons:

(25) Where is the product marketed?

(26) What is the distribution/marketing network in the place?

(27) Does the Group/Association provide facilities to members to transport their produce to the market Yes ( ), No. ( ).

(28) Do the members get credit facility from the Group/Association. Yes ( ), No. ( ). If Yes What are the terms and conditions?

(29) Personnel investment by the individual members/farmers:

(30) Level of Saving with the organization:

(31) What are the Storage facilities? (a: Individual ( ), b: Collective Storage Facilities

(' ) c: no storage facilities ( ).

(32) Business Linkage

(33) Advisory services Linkage

(34) Has your organization borrowed any loan from the bank or any other source: If Yes, please give details:

How much loan Terms condition of the loan

Interest on the loan Total No. of installments to be paid

Installments to be paid \& has not been paid (please give reasons). 
(35) To what extent is the organization helping the members: (e.g. Activity, Support)

Specially Marketing Related Activities

|S.No.

Activity

Support

(a)

(b)

(c)

(d)

(e)

(f)

(g)

(36) What measures are taken for risk protection.

(37) In your opinion what new methods/measures can be adopted by the member to improve the marketing standards.

(a) Improve Quality of the Produce ( ), (b) Improve Packaging ( )

(c) Introduce new products ( ), (d) Production of Off-season Produce ( )

(e) On time delivery of the produce ( ), (f) Better transport facilities ( )

(g) For quality produce easy availability of quality seed ( ),

(h) Easy access to market ( )

(I) Fruit Plants ( ), (j) Availability of Inputs e.g. Fertilizers, Pesticides ( )

(k) Others, please specify: 
(38) What Assistance/Support will you require and in what field. e.g. Group Development, Production Techniques, Marketing Techniques etc.

Please send us your organigram alongwith this questionnaire.

Respondent: Title/designation:

Signatures: Date:

Telephone No:

Questionnaire Prepared For: (HPU)

Project for the Horticulture Promotion

Swiss Technical Assistant Unit

Fruit \& Vegetable Development Board, opposite Islamia College, Jamrud Road, UPO Box 940, Peshawar, Pakistan.

Fax: 091-845572 Tel: 42296, 43505. E-mail: <phpstau @pes.comsats.net.pk> Name of the HPU Officer: Signature:

Date: Location Area: 


\section{Questionnaire for NGO's/CBO's}

(1) Name of the Organization:

(2) Abbreviated Name:

(3) Put a tick mark ( ) against the appropriate that best describes your organization: (You can tick more than one box)

a. Community Based Organization (CBO)

b. Village Organization (VO)

c. Women Organization (WO)

d. Village Development Organization (VDO)

e. Village Development Committee (VDC)

f. Village Development Local Committee (VDLC)

g. Non Government Organization (NGO)

h. Any other (Please Specify):

3. Official Address : House \#./Street:

Village/Town/City:

Tehsil: District/Agency:

Division:

Telephone: Fax:

E-mail/Internet:

4. Date/Year of Establishment/Formation of Organization:

5. Is your organization registered Yes ( ) No. ( )

(a) Date of Registration:

(b) Registration Number:

(c) With whom it is Registered: 
6. Is your organization a member, supported by or funded by any local regional or international Donor Agency? Yes ( ), No ( ) If yes (Please give details of the above): (e.g. Donor Name detail of the activities for which it has been funded.)

7. Has your organization borrowed any loan from the bank: If Yes please give details (e.g.

How much loan For what purpose

Terms \& condition of the loan

Interest on the loan Total No. of installments to be paid Installments to be paid \& has not been paid (please give reasons).

8. Does the Organization have other Branches/Regional Offices? Yes ( ), No. ( ) If yes please give details: i.e. (No. of Branches, Name \& Address of Branch).

\begin{tabular}{|l|l|l|l|}
\hline Sr.\#. & Name of Branch & Main Activity & Address \\
\hline & & & \\
\hline & & & \\
\hline & & & \\
\hline & & & \\
\hline
\end{tabular}


9. Which of the following best describes your organization?. (more than one choice is possible)
(a) Service delivery/Implementation
(b) Resource sharing
(c) Networking/Linkage
(d) Capacity building/HRD ( )

Any other (please specify)

10. What are the main objectives of your organization?

11. Structure of your organization?

11.1 Does the organization have a general body/board of directors? Yes ( ) No. ( )

(a) No. of male members: No. of female members: Total:

Male Female Total

(b) No. of Management Staff

(c) No. of Programme Staff

(e) No. of Support Staff

(f) Who is the main contact person of your organization? (please give name \& designation): 
12. What is the Geographic area of operation of your organization?

Urban ( ) Rural ( ) Both ( )

Kindly give details of the above:

\begin{tabular}{|l|l|l|l|l|}
\hline S.\#. & District/Agency & Tehsil & Union Council & Village/Town \\
\hline & & & & \\
\hline & & & & \\
\hline & & & & \\
\hline & & & & \\
\hline & & & & \\
\hline
\end{tabular}

13. Who are the Programme beneficiaries of your organization? (please give details)

14. In which of the following Fields/Sector your Organization is working?
(a) Agriculture
( ) (b) Community Development
( )
(c) Credit and saving
( ) (d) Education
( )
(e) Environment
( ) (f) Forestry/Tree plantation
( )
(g) Nature conservation ( )
(h) Women in Development
( )
Others (please Specify) 
15. If working in Agriculture Field/Sector?

(a) To what extent is the organization helping the farmers: (e.g. Activity, Support) $\longrightarrow$ Specially Marketing Related Activities

S.No. Activity

Support

(a)

(b)

(c)

(d)

(e)

(f)

(g)

(b) Is the organization working with the individual ( ) or

Farmers Group/Association( )

(c) Do the farmers get credit from the organization Yes ( ) No. ( )

If Yes. What are the terms and conditions (e.g. Ioan is provided on interest free basis, with interest. If loan is provided with interest, what is the percentage (recovery ratio.) of interest.

If No. what is the alternative method for providing credit to the farmers. 
(d) Does the organization provide services to the farmers i.e,

Training Facilities Yes ( ) No. ( ), Advisory Services Yes ( ) No. ( ),

Marketing/Promotion of the produce Yes ( ) No. ( ) etc. (please give details)

(e) In your opinion what is the best solution for the farmers to distribute/sell their produce in the market.

(I) Farmer him self as a Individual, Yes ( ) No. ( ).

(ii) Through Collective Marketing Association, Yes ( ) No. ( ).

(iii) Through Beoparis/Commission Agent, Yes ( ) No. ( ).

(iv) Pre-Harvest Sale, Yes ( ) No. ( ).

(v) Post-Harvest Sale, Yes ( ) No. ( ) Any other (Please Specify)

16. What assistance will you require to improve/promote the marketing of Agriculture/Horticulture in NWFP as a sector. 
17. In your opinion what new methods/measures can be adopted by the farmers to improve the marketing standards
(a) Improve Quality of the Produce（ ), (b) Improve Packaging ( )
(c) Introduce new products ( ), (d) Production of Off season Produce ( )
(e) On time delivery of the produce ( ), (f) Better transport facilities ( )
(g) For quality produce easy availability of quality seed ( ),
(h) Easy access to market ( )
(i) any more please specify:

18. What are Your Expectations from the:
(a) Government
(b) NGO's
(c) Another Projects
(d) Any other

Respondent:

Title/designation:

Telephone No:

Signatures: Date:

Questionnaire Prepared By:

Project for the Horticulture Promotion

Swiss Technical Assistant Unit

Fruit \& Vegetable Development Board,

Rear building, opposite Islamia College, University Road, University Campus P.O Box 940, Peshawar, Pakistan.

Fax: 091-845572 Tel: 42296, 43505.

E-mail: <phpstau @pes.comsats.net.pk> 
Meeting :

Venue/Location :

Group Name :

Registration Number:

List of members in the Group

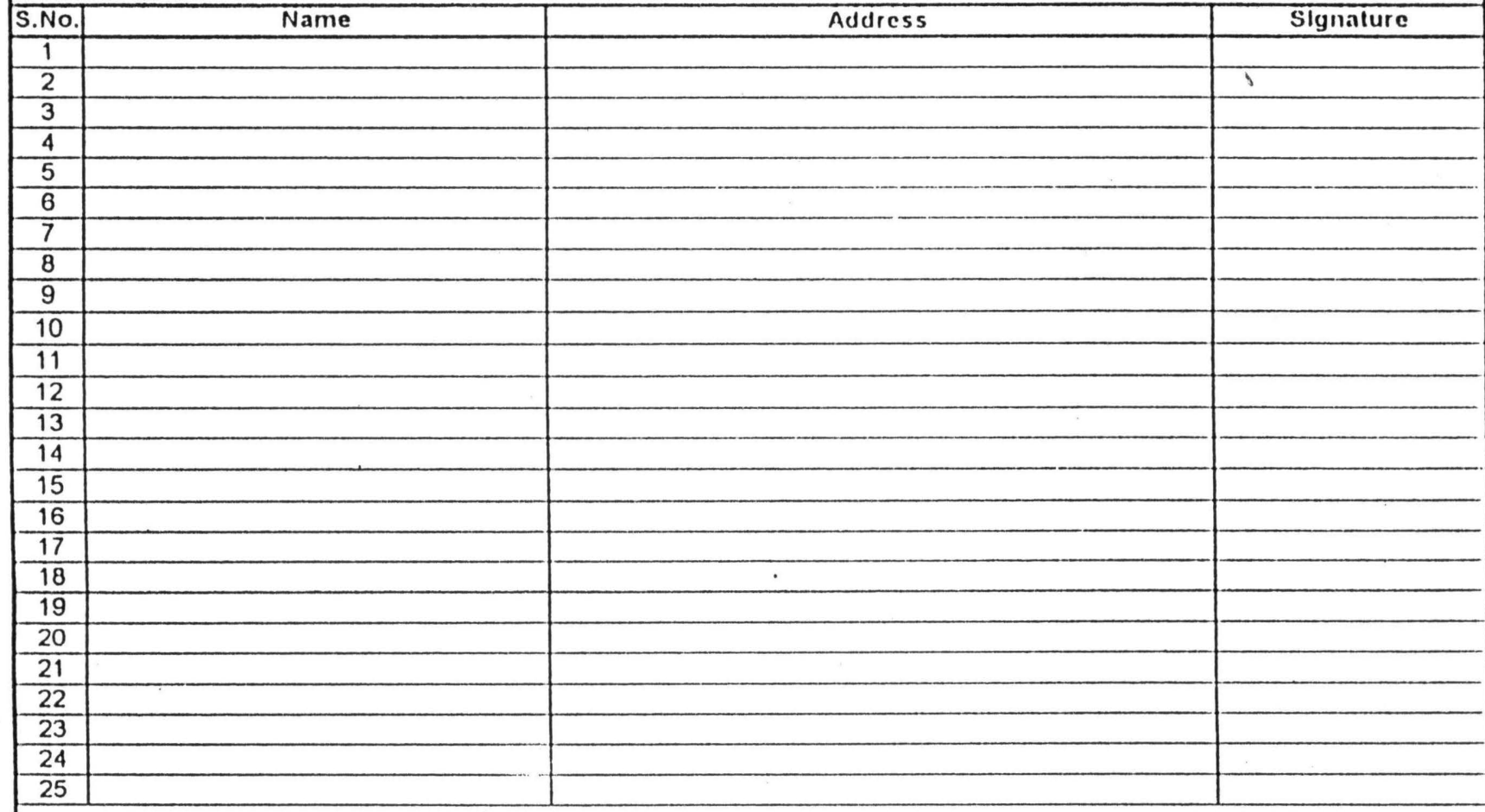

The following Persons were elected as executing body for a period of

\begin{tabular}{|c|l|l|}
\hline 1 & President & \\
\hline 2 & Vice President & \\
\hline 3 & General Secretary & \\
\hline 4 & Joint Secretary & \\
\hline 5 & Press \& Information Secretary & \\
\hline 6 & Finance Secretary & \\
\hline 7 & & \\
\hline 8 & & \\
\hline
\end{tabular}

List of participants from PHP/Bank/Other Organiation.

\begin{tabular}{|c|l|l|l|l|}
\hline 1 & & & \\
\hline 2 & & & \\
\hline 3 & & & \\
\hline 4 & & & \\
\hline 5 & & & & \\
\hline 6 & & & & \\
\hline 7 & & & & \\
\hline 8 & & & \\
\hline
\end{tabular}

$$
52 \text { GIRLSIXL's }
$$


Appendix 4

Improving the Access of Smallholders to Agricultural

Services in Sub-Saharan Africa: Farmer Co-operation and the Role of the Donor Community 
Group Name :

Details of the Loan

$-$

Date _ I I

Area/Location :

Date of Formation : __

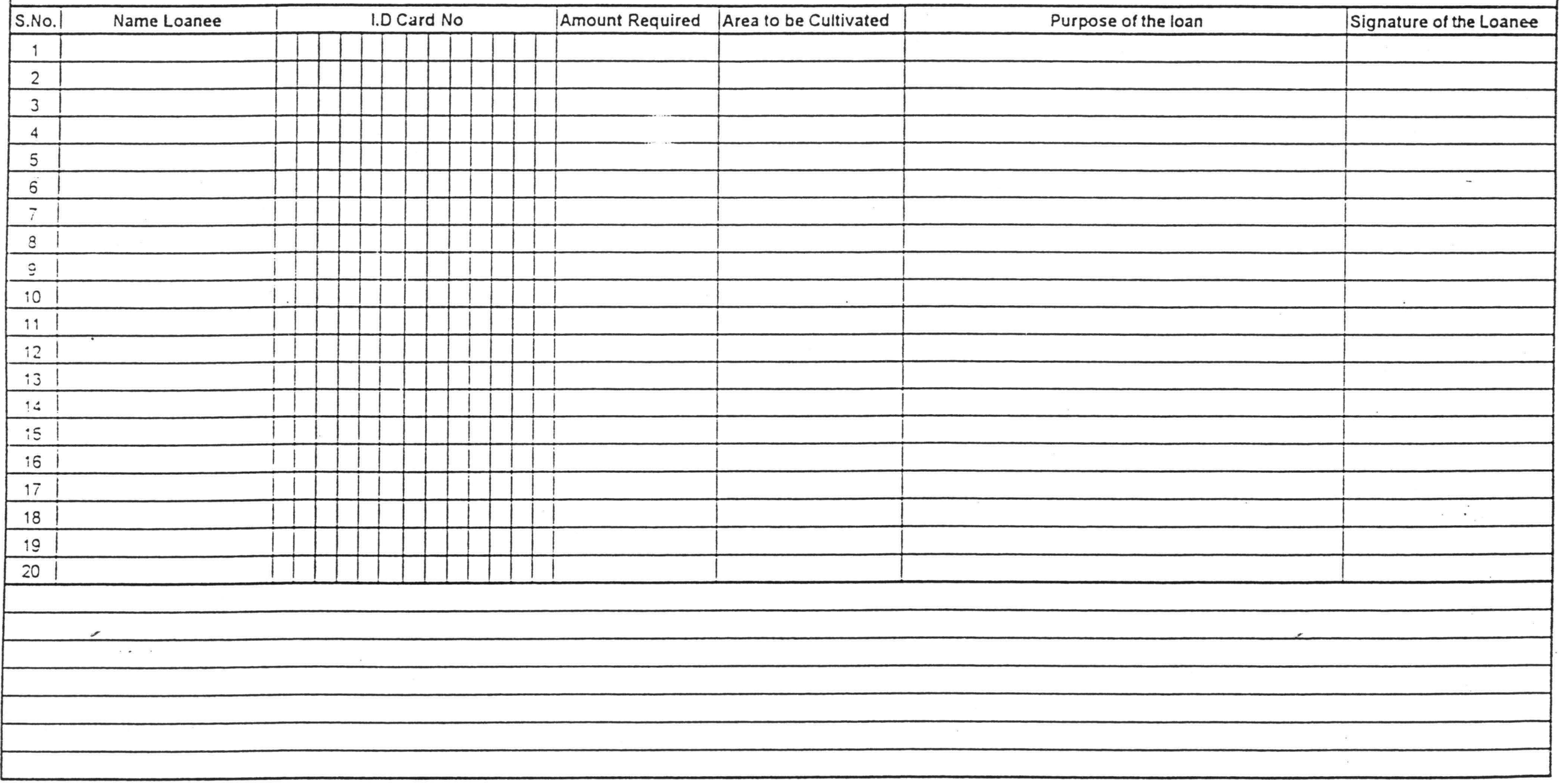




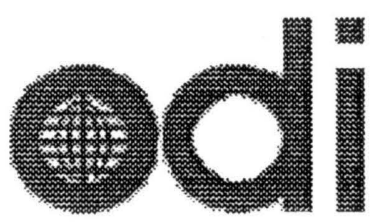

\section{Natural Resource perspectives}

Number 20, June 1997

The material that follows has been provided by Overseas Development Institute

\section{IMPROVING THE ACCESS OF SMALLHOLDERS TO AGRICULTURAL SERVICES IN SUB-SAHARAN AFRICA: FARMER COOPERATION AND THE ROLE OF THE DONOR COMMUNITY}

\section{Rachel Stringfellow, Jonathan Coulter, Trevor Lucey, Colin McKone and Ambereene Hussain}

Successful cooperation among smallholders requires a close match between their existing experience and financial capacity and the types of cooperation required by any joint activity. It is often built on previous cooperative experience. A commonsense observation, but one frequently overlooked by many donors in practice, is that the demands one places on farmer groups should not exceed their current group management skills. This paper highlights the characteristics of successful farmer cooperation as well as some of the common mistakes made in trying to promote farmer groups. The analysis indicates that though groups have a role to play, group approaches do not provide an easy institutional response to the new pressures facing smallholders in a liberalised economy. Nor should farmer cooperation be viewed as a panacea for the development of rural areas.

\section{Introduction}

Improving smallholder farmers access to agricultural services in Sub Saharan Africa is a central challenge facing governments in the region. Structural adjustment and a commitment to marketbased agricultural development have reduced the direct role of the state in providing services. In most countries publicly financed marketing boards have disappeared and access to unsecured and subsidised credit through government lending institutions is no longer available.
Policy conclusions

- Donors wishing to promote farmer cooperation should refrain from rushing the process of group formation or from overburdening groups with too many or too complex functions. They should avord providing subsidised credit or grants, but instead encourage farmers to develop their own forms of group organisation, based on an analysis of their own situation and the resources at their disposal.

- Assistance should be provided in establishing links to banks, input suppliers 
Private systems are emerging but there remains a question mark about their ability to fill adequately the gap left by state withdrawal, especially in the shortterm.

Farmer cooperation, especially among those having commercial potential, is widely perceived as one mechanism of improving their access to agricultural services. By working together farmers can realise the scale economies of bulk acquisition and enter into more stable relationships with suppliers or traders. By pooling resources to invest in transport or processing operations they can become more active participants in the marketing systems, adding value to their production. In recent years this view has influenced the design of many programmes of assistance to smallholders in Africa to the extent that donors and NGOs have often made group formation a prerequisite for accessing project resources. Additionally, from the donors perspective, there are significant advantages in distributing project resources to groups rather than to individuals, as costs are lower and resources can be disbursed more rapidly.

There is growing evidence, however, that projects promoting farmer cooperation do not always lead to the emergence of viable farmer groups. Project evaluations indicate that groups are often formed hastily and with little reference to underlying patterns of social and economic organisation or commitment to cooperative action. As a resuit many do not survive long and in the worst situation, members negative experiences contribute to undermining future self-help initiatives. In the light of this, policy-makers need to reassess the role that groups can play based on a more realistic understanding of what contributes to successful farmer cooperation.

\section{What factors contribute to successful farmer cooperation?}

\section{Matching skills and experience}

In the first place, there needs to be a close match between the levels of organisational and managerial capacity required by smallholders existing investment enterprises and those required by any future joint activity. Though this might seem an obvious point, there is much evidence to suggest that in practice such a common sense approach has had little influence on project design. In rural Africa, smallholders access to financial resources is likely to be severely constrained and local management experience limited. Yet many projects are designed on the assumption that both can be expanded rapidly.

The type of activity to be undertaken will have a major bearing on the management 
demands made on the group. These may range from coordinating marketing or procurement activities to operating jointly owned assets. Our research suggests that successful groups are more likely to be involved in the former. The skills and experience required to undertake these activities are often less complex than those required to operate a jointly owned piece of processing equipment. Box 1 illusirates this point in relation to fruit drying operations in Uganda.

On the other hand, in situations where there is a strong tradition of cooperative working, projects invlving the operation of jointly owned assets can sometimes work. In many parts of Africa processing activities are traditionally undertaken by groups of women and where these are developed sensitively and in line with market opportunities, successful groups have emerged, as the case of palm oil presses in Nigeria illustrates (Fayese, pers. comm.).

Donated or subsidised equipment has often had the opposite effect. The introduction of such assets immediately makes demands on a group which are likely to be well beyond its existing capacity, quite apart from undermining a commitment to selfhelp among its members. Box 2 describes the impact of donated equipment on a marketing project in Zimbabwe.

\section{Box 2. Horticultural marketing in Mashonaland East, Zimbabwe}

The EU has been involved since 1988 with a major project to assist smallholders ivolved in horticultural production in Mashonaland East. Though the project initially focused on improving production and productivity, a second phase emphasised marketing and institutional development.

The lack of transport facilities had been identified as a major constraint, leading to the project strategy of forming farmer associations to operate donated trucks.
A relatively less complex activity is group borrowing where members are jointly and severally liable. Whilst it requires a high level of trust among members, and some commitment of time, in return members benefit from improved access to loans. However, not all group borrowing schemes have been successful. Two important factors appear to influence success: groups must be self-selecting if peer pressure is to be effective and they should preferably be producing a high value commodity (for example cocoa or horticultural products for export) 


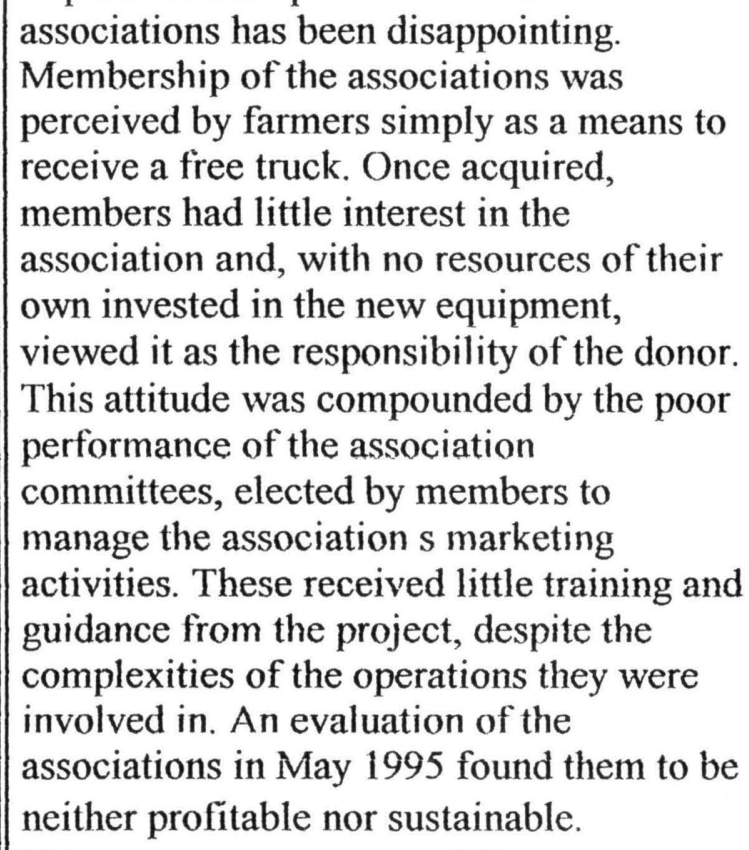

Internal cohesion and a clear memberdriven agenda are central to successful farmer cooperation. Small size, homogeneity and face-to-face contact facilitate these features, as well as accountability among members. Small size and homogeneity are most important where the group activity requires a commitment of financial resources to a shared enterprise. On the other hand, where the group s primary function is to liaise on behalf of its members with a buyer or supplier, larger and more heterogeneous groups may be at less of a disadvantage.

However, some donors and NGOs have promoted large groups for marketing or processing because of scale-economies, particularly when they need to acquire vehicles or processing equipment. There is often a trade-off between economies of scale and group cohesion, and group cohesion is a critical factor for sustained success.

Previous experience of group or cooperative activity can make an important contribution to the development of cohesive groups. Among women, traditional group processing, savings clubs and petty trading are common. Labour-sharing groups among men and women are also common and a shared religious idẹtity provides the antecedents for many self-help groups.

Relations with external agents have an important impact on the development of a group s internal dynamics. Unsurprisingly, where politicians try to manipulate group development through e.g. favoured access to resources, the results contribute little to genuine farmer cooperation. Whatever the source, free or subsidised resources tend to attract people seeking hand-outs and do not necessarily create business opportunities.

\section{Strong business rationale and relationships with the private sector}

Good internal organisational features are no substitute for a strong business rationale, which is thus the third feature of successful group activity. Fundamental to this is the group s successful integration into the wider economy.

Two types of relationship operate between farmer groups and external markets. In linkage-independent cases, the group stands alone, providing smallholder members with sufficient market presence to seek out independent relationships with other market intermediaries, for example banks or buyers. A linkage-dependent group depends on a particular outside agency which in effect supervises its activity. This could be, for instance, a private marketing company or a bank which provides

file://D:LMy Documents\Afghan report\Appendix - farmer groups.htm

$4 / 21 / 00$ 
working capital to group members.

Linkage-independent groups offer independence and autonomy. Their success depends primarily on the skills and experence of members. Linkage-dependent groups not only rely on these, but also on the support of the company or bank to which they are linked and which has a vested interest in their survival. Whilst this potentially places such a group in a weak bargaining position, it can provide members with many of the benefits of farmer cooperation in return for a much lower commitment of managerial and entrepreneurial skill than that required by independent groups. Box 3 provides examples of linkage-dependent groups in Ghana and Uganda.

In the past donors and NGOs have tended to promote independent farmer groups, often organised into federations and confederations, rather than links between groups of farmers and banks or private companies. Whilst some donors and NGOs are continuing this approach, others are setting up programmes which promote linkages between groups of farmers and the private sector.

\section{What role should donor agencies and NGOs play in promoting farmer cooperation?}

\section{What donors should not do}

To avoid undermining the process of successful group development donors should:

- Refrain from rushing the process of group formation. If donors drive the process, e.g. by setting numerical targets for number of groups formed, responsibility is taken away from the group members.
Box 3. Linkage dependent groups in Ghana and Uganda

\section{Barclays Bank and cocoa farmers in Ghana}

Since 1988 Barclays Bank of Ghana has been lending to groups of cocoa farmers through the existing network of cocoa primary societies operating under the Produce Buying Company.

Applicants for the scheme are screened by the society s committee and by the bank $\mathrm{s}$ agricultural officer. Successful applicants form groups of between 10 and 15 members which are jointly liable for the repayment of all loans made to the group. Members also contribute to a group security fund deposited with the bank. Non-payment by any member of the group automatically disqualifies the other members from the scheme the following year.

Liberalisation of cocoa marketing has created a new challenge for the scheme as the proliferation of alternative marketing outlets has made it harder to monitor farmers to ensure repayment. But despite this, in early 1995-96 Barclays had almost 3,500 borrowers and is achieving a recovery rate of $99.6 \%$.

UVAN Ltd and groups of associations of vanilla farmers in Uganda

UVAN Ltd is a private company which buys, processes and exports vanilla. It works with groups of farmers organised into associations. This facilitates the company s operations as the associations play a role in selecting suitable farmers for participation in the company s lending programme, recovering loans and bulking up and assessing the quality of vanilla for purchase. They also mobilise farmers to attend training programmes provided by the company and negotiate with the company on the price paid for vanilla each season. 
- Not require groups to undertake many or complex functions, especially early on and in projects involving the joint ownership of assets.

- Avoid providing subsidised credit or grants, especially in the initial stages of group development.

Those who work in donor organisations will know that this is easier said than done. On the one hand, there are often powerful pressures to identify projects and disburse funds. On the other, project planning and register of companies. Each association agrees on common objectives and rules and UVAN Ltd provides some secretarial support and legal assistance.

Each association has a voluntary executive committee and members are required to pay subscriptions. Benefits to members through membership of the Association are improved access to extension services; timely marketing of produce and immediate cash payments; a collectively negotiated price for vanilla; and access to financial services. review mechanisms do not generally allow changes to be made in response to new findings, so that once objectives and targets are fixed, achieving them tends to become an end in itself. To overcome this situation will require profound changes in the philosophy and operations of the organisations themselves.

\section{What donors should do}

Good practice in the field suggests that the best approach to assist groups of farmers is by encouraging them:

- To analyse arrangements with regard to market access.

- To consider ways of improving this.

- To implement their preferred option, and invest their own resources in the enterprise.

This approach has a much higher likelihood of producing groups controlled by members, and the types of activity proposed are mre likely to be consistent with what local people feel they can achieve and with previous experience of group cooperation.

Outside support should be provided by the donor at the community s request, and might involve the provision of training, knowledge and contacts to help the community identify and implement its preferred option. Training may involve literacy, leadership and organisational skills as well as technical training to improve the quality of marketed production, for example. Requests for financial resources should be treated with caution, and where needed, groups should be encouraged to approach banks or similar specialised institutions.

The promotion by donors of links with the private sector can bring benefits to smallholders in terms of access to finance, inputs and new markets. The promotion of autonomous groups is likely to require a higher investment in training and capacity building than that required by linkage-dependent groups. On the other hand, even these groups will require sufficient technical and business training to allow them to enter into mutually beneficial agreements with buyers. 
Box 4 provides examples of projects in Africa which appear to be applying this approach.

\section{Box 4. A client-led and market-oriented approach to promoting farmer cooperation}

\section{The Kafo Project, Sikasso Region, Mali}

Funded by the World Bank, the Kafo Project is promoting agricultural diversification in an area traditionally dominated by cotton and where the marketing of other comodities is weak. The project is involved in a range of activities, many of which involve farmer cooperation, including training to improve the quality of what is marketed; support to producer associations, linking them directly with buyers; the dissemination of market information to producers and the linking of groups of smallholders to financial institutions.

\section{Cooperative League of the United States (CLUSA)}

Together with local partners, CLUSA has engaged in long-term farmer-group programmes in various countries of Africa, notably Niger, Mali, Cape Verde and Mozambique. The approach has involved a heavy emphasis on functional literacy training. Armed with this tool and with CLUSA s advisory support, farmers identify their own business activities, and develop them according to their own wishes. This will typically involve group members drawing up business plans, seeking bank funding, finding buyers, and negotiating input supply contracts.

\section{Intermediate Technology Development Group, Zimbabwe}

This NGO is working with farmers in some of the driest areas in the Chivi district of Zimbabwe. Farmers are encouraged to form groups to analyse their problems together. No material assistance is given other than training in problem analysis and soil and moisture conservation techniques. In many groups traditional forms of leadership have re-emerged. Marketing activities are a priority for the groups who see the opportunity to market cash crops as a way out of subsistence farming. A number of groups have established marketing links with buyers in the towns, including Chibuku breweries which purchases sorghum for beer making.

\section{Policy issues relevant to a participatory and market-oriented approach}

The relatively recent emergence of this approach to rural enterprise development, coupled with limited experience in the field, leaves a number of key policy and programme design issues open to further discussion.

One relates to the role of publicly funded activities within a private sector framework. To what extent should public resources be used to promote market integration if the beneficiaries are not just smallholders but large companies as well? If a company believes that it is in its interests to work with smallholders, is it not reasonable to expect that it will get on with developing these links itself?

One area where assistance might be justified is in developing and piloting new institutional arrangements between companies, banks and smallholders which are mutually acceptable in terms of risk-sharing and the distribution of benefits. Liberalisation in Africa has created many new export opportunities for private companies, but in many countries agribusiness is finding it difficult to develop file://D:LMy Documents\Afghan report\Appendix - farmer groups.htm 
supply networks involving smallholders. Zambia and Zimbabwe s burgeoning horticultural industries are almost entirely supplied by commercial farmers. If smallholders are to be important suppliers, they need working capital or input loans, but agribusiness is reluctant to provide such support because of poor credit discipline, spurred by debt forgiveness in past lending programmes.

\begin{abstract}
Box 5 illustrates the problem in relation to an established horticultural export company in Zimbabwe.
\end{abstract}

Assistance could also be provided directiy to groups of farmers in the form of training, especially in organisational and business skills, in order to improve their ability to negotiate effectively with contracting companies.

Responsibility for the provision of training services needs careful consideration. If a donor does this directly, through its own project staff, then when the project finishes, the institutional capacity to continue training disappears with it. A more sustainable approach is likely to involve an established institution. In some countries this might be the farmers union where this has a wide membership, for example the Zimbabwe Farmers Union. In some cases, the government agricultural extension system might be involved, but inappropriate motivation and outlook may present problems.

Marketing issues tend to lie outside the responsibility of extension agents and when this is not the case they may be required to put over official messages rather than promote a participatory process. If extension agents are to be used, they are likely to require extensive training. Another alternative might be to work through local NGOs with an established presence in the project area.

The longterm financing of training services is another issue. To be sustainable beyond

\section{Box 5. Cracking the nut of working capital}

Hortico is a commercial horticultural company about $40 \mathrm{~km}$ outside Harare and is involved in growing high value crops for export.

The vast majority of production comes from the company s outgrowers who are commercial farmers in the area. But the company has also assisted some smallholders in overhead irrigation and trained them in crop production, working closely with government extension officers. Until recently, it has also provided working capital, making deductions for loans from final payments.

The company is presently considering a new business venture to increase the number of its smallholder growers from 200 to 3,000 . The company anticipates providing fixed assets (transport, cold stores etc) as well as training and supervision, but it cannot provide working capital to an expanded number of growers given the high risks involved.

According to the company s Financial Director, this represents a major problem as smallholders do not have the necessary security to get bank loans and even the Agricultural Finance Corporation, which used to be an easier source of financing for smallholders, will no longer make unsecured loans. In his own words, cracking the working capital nut is the major challenge facing the company. Given that individual smallholders do not have assets against which loans can be secured, one way forward may be to develop group lending among smallholders with the group putting up a security fund of sufficient value to deter prospective 
the life of any conor-assisted project, cost || detaulters. recovery needs to be considered from the outset. The degree to which any programme of this kind can or should become selffinancing is a closely related issue.

Finally, donors need to adapt their project planning procedures to the nature of cooperative enterprises. At least in the early stages, traditional quantitative measures of project achievement, for example the number of groups established or the number of farmers benefited, will not be appropriate. Instead, there may be a need for a pilot or even research phase in which different approaches to cooperation can be tested and validated. Where this leads to effective forms of farmer cooperation, other farmers may well emulate what they see, making dissemination to a large extent spontaneous. Subsequent project activities can support this process and encourage long-term sustainability.

\section{Conclusions}

\section{The benefits of farmer} cooperation are most likely to be realised when donors adopt an approach which is both participatory and market oriented. A number of projects in Africa are adopting this approach and central to their success is the promotion of effective links between groups of smallholders and the private sector.
The research on which this paper was based was funded by ODA (now DFID) and jointly undertaken by NRI and the Plunkett Foundation (project leader: J. Coulter, NRI). Fieldwork was undertaken during 1995 and 1996 in Ghana, Uganda, Zimbabwe, Mali and Burkina Faso. Separate reports are available on each country case study from the Plunkett Foundation and a Synthesis Report is also available.

Jonathan Coulter can be contacted at:

The Natural Resources Institute, The University of Greenwich, Central Avenue, Chatham Maritime, Kent ME4 4TB, UK Internet:

http://www.nri.org

Tel: +44 (0)1634 880088 Fax: +44 (0)1634 880066/77

Trevor Lucey, Colin McKone and Ambereene Hussain can be contacted at:

The Plunkett Foundation, 23 Hanborough Business Park, Long Hanborough, Oxfordshire

OX8 8LH, UK. Tel: +44 (0)1993 883636 Fax: +44 (0)1993883576

Rachel Stringfellow can be contacted c/o Jonathan Coulter at the Natural Resources Institute (see above)

\footnotetext{
Natural Resource Perspectives present accessible information on important development issues. Readers are encouraged to quote from them for their own purposes or duplicate them for colleagues but, as copyright holder, ODI requests due acknowledgement. The Editor welcomes readers comments on this series.

Design: Peter Gee Administrative Editor: Alison Saxby Series Editor: John Farrington
}

ISSN: 1356-9228

C)Copyright:Overseas Development Institute 1997

\section{Portland House \\ Stag Place}

London SW1E 5DP, UK 
Fax +44 (0)171 3931699 Email: nrp@odi.org.uk

a 0 Overseas Development Institute Home Page


Appendix 5

A brief guide to minimize microbial food safety hazards for fresh fruits and vegetables 


\section{U. S. Food and Drug Administration \\ Center for Food Safety and Applied Nutrition}

\section{The Guide at a Glance}
The Guide $\geq \leq$ to $\geq \leq$ Minimize $\geq \leq$ Microbial $\geq \leq$ Food $\geq \leq$ Safety $\geq \leq$ Hazards $\geq$ $\leq$ for $\geq \leq$ Fresh $\geq \leq$ Fruits $\geq$ and $\leq$ Vegetables $\geq$ In Brief

This Guide provides general, broad-based voluntary guidance that may be applied, as appropriate, to individual operations

\section{The Guide}

- Is intended to assist domestic and foreign growers, packers, and shippers of unprocessed or minimally processed (raw) fresh fruits and vegetables by increasing awareness of potential hazards and providing suggestions for practices to minimize these hazards

- Covers agricultural and postharvest water uses, manure and biosolids, worker health and hygiene, field and facility sanitation, transportation, and traceback

- Does not impose any new requirements or supercede existing laws or regulations

- Will be most effective when used to evaluate individual operations and to institute good agricultural and good manufacturing practices (GAPs and GMPs) appropriate to the individual operations

Basic Principles include

- Prevention of microbial contamination of fresh produce is favored over reliance on corrective actions once contamination has occurred

- Accountability at all levels of the agricultural and packing environments is important to a successful food safety program

Water

Wherever water comes into contact with fresh produce, its quality dictates the potential for pathogen contamination

\section{Agricultural Water}

- Identify source and distribution of water used

- Be aware of current and historical use of land

- Review existing practices and conditions to identify potential sources of contamination. Consider practices that will protect water quality 
- Maintain wells in good working condition

- Consider practices to minimize contact of the edible portion of fresh produce with contaminated irrigation water. Where water quality is good, risk is low regardless of irrigation method

\section{Processing Water}

- Follow GMPs to ensure water quality is adequate at the start of and throughout all processes

- Maintain water quality, such as by periodic testing for microbial contamination, changing water regularly, and cleaning and sanitizing water contact surfaces

- Antimicrobial chemicals may help minimize the potential for microbial contamination to be spread by processing water; levels of antimicrobial chemicals should be routinely monitored and recorded to ensure they are maintained at appropriate levels

- As organic material and microbial load increase, the effectiveness of many antimicrobial chemicals will decrease. Filtering recirculating water or scooping organic material from tanks may help reduce the build-up of organic materials

\section{Cooling Operations}

- Maintain temperatures that promote optimum produce quality and minimize pathogen growth

- Keep air cooling and chilling equipment clean and sanitary

- Keep water and ice clean and sanitary

- Manufacture, transport, and store ice under sanitary conditions

\section{Manure and Municipal Biosolids}

\section{Properly treated manure or biosolids can be an effective and safe fertilizer.}

- If manure is used as a fertilizer, it should be managed to minimize microbial hazards

- Federal regulations address the requirements for use of biosolids in the U.S.. Some states also have specific requirements for the use of biosolids. Foreign growers should follow these or similar requirements

\section{Manure}

- Use treatments to reduce pathogens in manure and other organic materials. Treatments may be active (e.g., composting) or passive (e.g., aging)

- Manure treatment and storage sites close to fresh produce fields increase the risk of contamination 
- Consider factors such as slope and rainfall and the likelihood of runoff into fresh produce production areas

- Use barriers or physical containment to secure storage and treatment sites

- Protect treated manure from being re-contaminated

- When purchasing treated manure, get information about the method of treatment

- Maximize the time between application of manure to production areas and harvest

- Use of raw manure on produce during the growing season is not recommended

\section{Animal Feces}

While not possible to exclude all animal life from fresh produce production areas, many field programs include elements to protect crops from animal damage.

- Domestic animals should be excluded from fields and orchards during the growing and harvesting season

- Follow GAPs to ensure animal waste from adjacent fields, pastures, or waste storage facilities does not contaminate fresh produce production areas. Where necessary, consider physical barriers such as ditches, mounds, grass/sod waterways, diversion berms, and vegetative buffer areas

- Control of wild animal populations may be difficult or restricted by animal protection requirements. However, to the extent feasible, where high concentrations of wildlife are a concern, consider practices to deter or redirect wildlife to areas where crops are not destined for fresh produce markets

\section{Worker Health and Hygiene}

Infected employees who work with fresh produce increase the risk of transmitting foodborne illness.

- Train employees to follow good hygienic practices

- Establish a training program directed towards health and hygiene - include basics such as proper handwashing techniques and the importance of using toilet facilities

- Become familiar with typical signs and symptoms of infectious diseases

- Offer protection to workers with cuts or lesions on parts of the body that may make contact with fresh produce

- If employees wear gloves, be sure the gloves are used properly and do not become a vehicle for spreading pathogens 
- Customer-pick and road-side produce operations should promote good hygienic practices with customers - encourage handwashing, provide toilets that are well equipped, clean, and sanitary and encourage washing fresh produce before consumption

Sanitary Facilities

- Poor management of human and other wastes in the field or packing facility increases the risk of contaminating fresh produce

- Be familiar with laws and regulations that apply to field and facility sanitation practices

- Toilet facilities should be accessible to workers, properly located, and well supplied

- Keep toilets, handwashing stations, and water containers clean and sanitary

- Use caution when servicing portable toilets to prevent leakage into a field

- Have a plan for containment in the event of waste spillage

\section{Field Sanitation}

Fresh produce may become contaminated during pre-harvest and harvest activities from contact with soil, fertilizers, water, workers, and harvesting equipment.

- Clean harvest storage facilities and containers or bins prior to use

- Take care not to contaminate fresh produce that is washed, cooled, or packaged

- Use harvesting and packing equipment appropriately and keep as clean as practicable

- Assign responsibility for equipment to the person in charge

\section{Packing Facility}

Maintain packing facilities in good condition to reduce the potential for microbial contamination.

- Remove as much dirt as practicable outside of packing facility

- Clean pallets, containers, or bins before use; discard damaged containers

- Keep packing equipment, packing areas, and storage areas clean

- Store empty containers in a way that protects them from contamination

\section{Pesl Control}

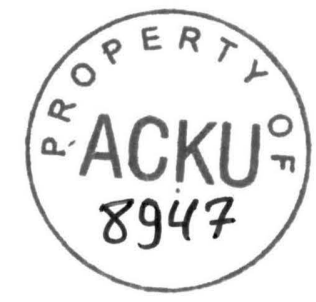

- Establish and maintain a pest control program 
- Block access of pests into enclosed facilities

- Maintain a pest control log

\section{Transportation}

Proper transport of fresh produce will help reduce the potential for microbial contamination.

- Good hygienic and sanitation practices should be used when loading, unloading, and inspecting fresh produce

- Inspect transportation vehicles for cleanliness, odors, obvious dirt and debris before loading

- Maintain proper transport temperatures

- Load produce to minimize physical damage

Traceback

The ability to identify the source of a product can serve as an important complement to good agricultural and management practices.

- Develop procedures to track produce containers from the farm, to the packer, distributor, and retailer

- Documentation should indicate the source of the product and other information, such as date of harvest, farm identification, and who handled the produce

- Growers, packers and shippers should partner with transporters, distributors and retailers to develop technologies to facilitate the traceback process

Once good agricultural and management practices are in place, ensure that the process is working correctly. Without accountability, the best efforts to minimize microbial contamination are subject to failure.

Copies of the $\leq$ Guide $\geq \leq$ to $\geq \leq$ Minimize $\geq \leq$ Microbial $\geq \leq$ Food $\geq \leq$ Safety $\geq \leq$ Hazards $\geq \leq$ for $\geq$

$<$ Fresh $><$ Fruits $>$ and $<$ Vegetables $>$, October 1998, are available from:

Food Safety Initiative Staff (HFS-32)

U.S. Food and Drug Administration

Center for Food safety and Applied Nutrition

200 C Street SW

Washington, DC 20204

Or on the Internet at:

http://vm.cfsan.fda.gov/ dms/prodguid.html 
The $\leq$ Guide $\geq \leq$ to $\geq \leq$ Minimize $\geq \leq$ Microbial $\geq \leq$ Food $\geq \leq$ Safety $\geq \leq$ Hazards $\geq \leq$ for $\geq \leq$ Fresh $\geq$ $\leq$ Fruits $\geq$ and $\leq$ Vegetables (English) (Español) (Français) (Português ) (p>

Home | Food Safety Initiative

Hypertext updated by dms/ear 2000-MAR-09 


\section{Appendix 6}

Sample costs to establish an almond orchard and produce almonds, Northern San Joaquin Valley - Flood Irrigation 


\section{8}

\section{UNIVERSITY OF CALIFORNIA - COOPERATIVE EXTENSION}

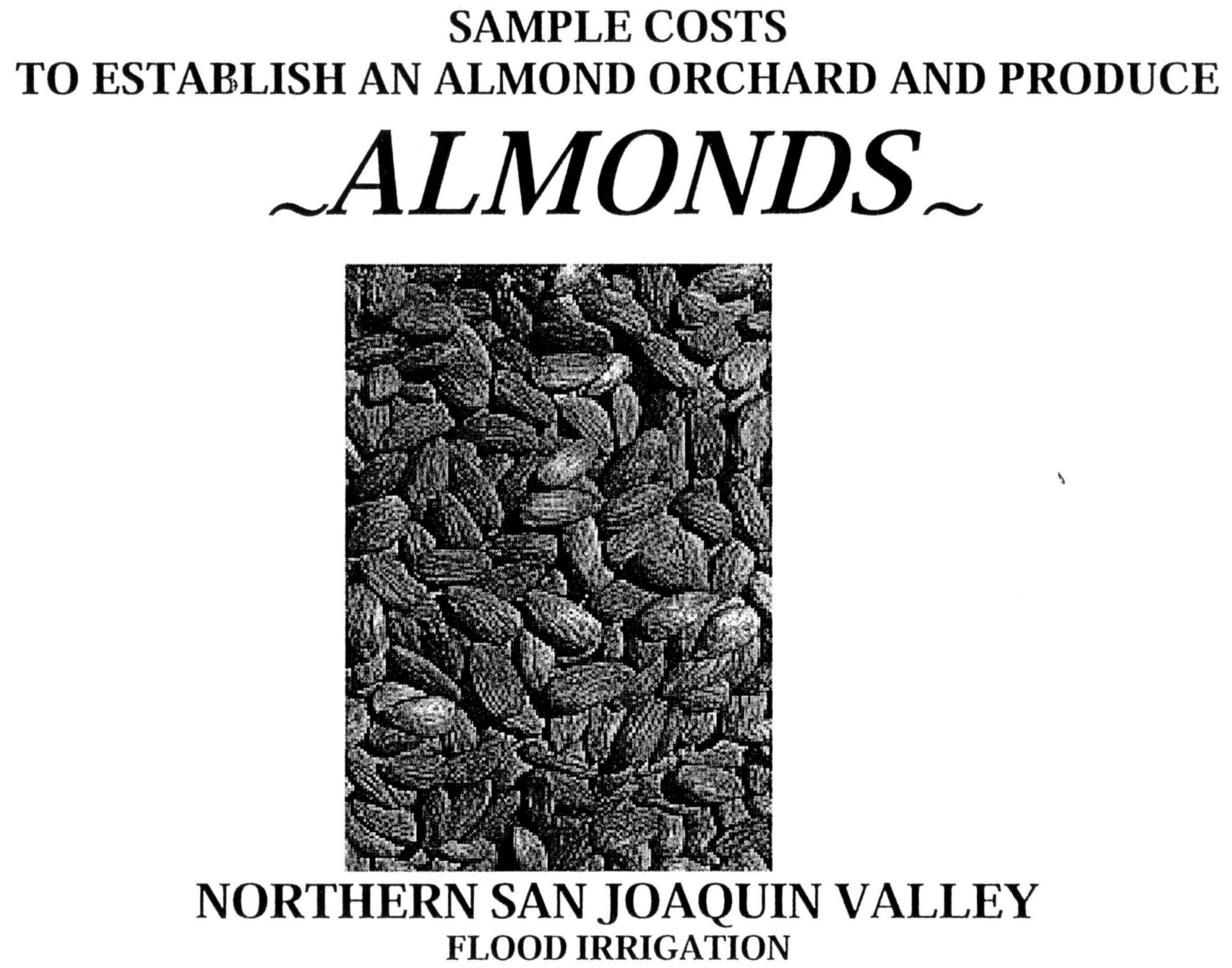

Prepared by:

Lonnie Hendricks

Roger Duncan

Paul Verdegaal

Karen Klonsky

Pete Livingston
U.C. Cooperative Extension Farm Advisor, Merced County

U.C. Cooperative Extension Farm Advisor, Stanislaus County

U.C. Cooperative Extension Farm Advisor, San Joaquin County

U.C. Cooperative Extension Economist, Department of Agricultural and Resource Economics, U.C. Davis

U.C. Cooperative Extension Staff Research Associate, Department of Agricultural and Resource Economics, U.C. Davis 


\section{8 \\ SAMPLE COSTS TO \\ ESTABLISH AN ALMOND ORCHARD AND PRODUCE ALMONDS \\ Northern San Joaquin Valley \\ Flood Irrigation}

\section{INTRODUCTION}

Detailed costs of establishing an almond orchard and production of almonds under flood irrigated conditions in the Northern San Joaquin Valley are presented in this study. The hypothetical farm used in this report is 100 acres, 95 of which are planted to almonds.

This study consists of Assumptions for Establishing an Almond Orchard and Producing Almonds and eight tables. It is intended as a guide only. It can be used to make production decisions, determine potential returns, prepare budgets and evaluate production loans. Sample costs given for labor, materials, equipment and contract services are based on current figures. Some costs and practices detailed in this study may not be applicable to every situation. A blank, Your Cost, column is provided to enter your actual costs on Table 2 Costs Per Acre To Produce Almonds and Table 3 Costs And Returns Per Acre to Produce Almonds.

Tables included:

Table 1. Costs Per Acre to Establish An Almond Orchard

Table 2. Costs and Returns Per Acre to Produce Almonds

Table 3. Costs Per Acre to Produce Almonds

Table 4. Monthly Cash Costs Per Acre to Produce Almonds

Table 5. Whole Farm Annual Equipment, Investment and Business Overhead

Table 6. Hourly Equipment Costs

Table 7. Ranging Analysis

Table 8. Cost and Returns/Breakeven Analysis

This and other studies can be obtained through the Department of Agricultural and Resource Economics, U.C. Davis (530-752-1515), or from selected county Cooperative Extension offices. For an explanation of calculations or assumptions used in this study refer to the attached General Assumptions or call the Department of Agricultural and Resource Economics, Cooperative Extension, University of California, Davis, California, (530752-3589) or the farm advisor in the county of interest.

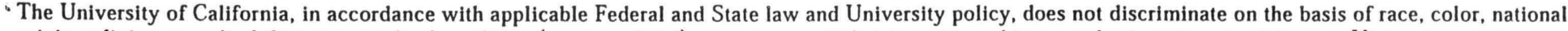

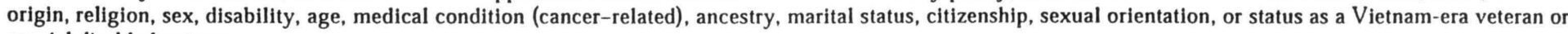
special disabled veteran.

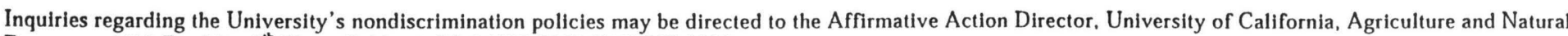
Resources, 1111 Franklin, $6^{\text {th }}$ Floor, Oakland, CA 94607-5200 (510) 987-0096.
} 


\section{8 \\ SAMPLE COSTS TO \\ ESTABLISH AN ALMOND ORCHARD AND PRODUCE ALMONDS \\ Northern San Joaquin Valley \\ Flood Irrigation}

\section{ASSUMPTIONS}

The following are general assumptions pertaining to sample costs of establishing an almond orchard and producing almonds using micro-sprinkler irrigation in the Northern San Joaquin Valley. Practices described are not recommendations by the University of California, but represent production procedures and materials considered typical of a well managed orchard for the Northern San Joaquin Valley. Costs and practices detailed in this study may not be applicable to all situations. Establishment and cultural practices vary by grower and region; variations can be significant. These costs are on an annual, per acre basis. The use of trade names in this report does not constitute an endorsement or recommendation by the University of California nor is any criticism implied by omission of other similar products.

Land. The farm consists of 100 acres of land. Of that, a mature almond orchard covers 55 acres, 40 acres are being established, and five acres are occupied by roads, irrigation systems and farmstead. The orchard is farmed by the owner. Additional management costs ranging from $\$ 60$ to $\$ 100$ per acre may occur if additional practices are contracted. The orchard is in land previously planted to other field and row crops. Land is valued at $\$ 7,500$ per acre. Because only 95 of the 100 acres is planted with almonds the land cost is $\$ 7,895$ per producing acre.

Trees. No specific varieties of almond trees are assumed in this study. Orchards will include at least two varieties (and preferably three) in which pollen shedding and bloom periods overlap. At least two varieties are included within each orchard to insure good pollination. A few of the cultivars representing the majority of almond acreage in California that might be planted in this region include: A) Early blooming _ Sonora; B) Midblooming _ Nonpareil, Carmel, Monterey, Price, and Fritz; and C) Later blooming _ Mission, Padre, and Butte. The trees are planted at 110 trees per acre. The life of the orchard at the time of planting in this study is estimated to be 25 years. The annual report by the Almond Board of California contains the current acreage trends by varieties.

Irrigation System. The orchard is irrigated using a flood irrigation system with permanent berms (raised rows) on which the trees are planted. Berms are not ridged up or knocked down during the remaining life of the orchard. Irrigating the orchard during the first few establishment years is accomplished by running water down furrows made along each side of the tree rows. This type of application could reduce water applied during the early years, but is not assumed in this study.

Water is delivered to the orchard from the district ditch through an underground pipe and alfalfa valve system. The life of the irrigation system is estimated to be 25 years. The irrigation system is installed before the orchard is planted. The irrigation system is considered an improvement to the property and is represented in Table 5 in the Annual Investment Costs section. 
Labor. Hourly wages for workers are $\$ 8.75$ for skilled and $\$ 5.75$ per hour for field workers. Adding $34 \%$ for Workers Compensation, Social Security, Medicare insurance, and other possible benefits gives the labor rates shown of $\$ 11.73$ per hour for skilled labor, and $\$ 7.71$ per hour for field labor. Labor for operations involving machinery are $20 \%$ higher than the operation time given in Table 2 to account for the extra labor involved in equipment set up, moving, maintenance, work breaks, and repair. Wages for management are not included as a cash cost. Returns above total costs is considered a return to management and risk.

\section{Orchard Establishment Cultural Practices and Material Inputs}

Site Preparation. This orchard is established on ground that has been previously planted to field and row crops. The land is assumed to be well drained and either a class I or II soil. Growers should have nematode sampling done before deciding whether to fumigate or not.

The site is first leveled so high and low spots are removed in order to allow for efficient irrigation. Tree holes are dug by a contract backhoe service. After the holes are dug, a contract fumigation company treats the site for soil-borne disease and pests. The fumigation is made only down the strip where the trees will be planted. Subsequently, the orchard site is disked and floated twice. Following the discing and floating, berms are constructed in the tree rows to maintain irrigations between the rows. All operations that prepare the orchard for planting are normally done the year prior to planting, but costs are shown in the first year.

Planting, Training, And Pruning. Planting the orchard starts by surveying and marking tree sites. Trees are planted, painted, and covered with a milk carton. The milk cartons are placed around trees and trunks are painted for protection against above ground rodents, herbicide sprays, and sunburn. In the second year, 2 trees per acre will have to be replanted and in the third year an additional tree will be replaced. Pruning, training, and suckering begin the first year and labor time required for pruning increases in the subsequent years.

Fertilization. Nitrogen and potassium fertilizers are applied for tree growth and nut production. Nitrogen is applied along the tree rows beginning the first year. Split applications of $N$ are made between spring and fall. A postharvest application of potassium in the form of potassium sulfate is made in the third year. Annual rates of $\mathrm{N}$ and potassium used in this study are shown in Table $\mathrm{A}$.

Table A. Applied nitrogen and potassium during establishment years

\begin{tabular}{crrc}
\hline Year & Lbs Of N/Acre & Lbs Of N/Tree & Lbs Of Potassium Sulfate/Acre \\
\hline 1 & 27.5 & 0.25 & 0 \\
2 & 55 & 0.5 & 0 \\
3 & 110 & 1.0 & 110 \\
4 & 150 & 1.4 & 150 \\
5 & 180 & 1.6 & 180 \\
6 & 220 & 2.0 & 220 \\
\hline
\end{tabular}

Irrigation. Water for irrigation is supplied by a water district. The price per acre or acre-foot varies by district in this region. In this study district water costs $\$ 10.83$ per acre-foot. Growers pumping well water for irrigation may have higher cost per acre-foot depending on the amount of water pumped, energy source and various well characteristics. 
A total of 48 acre-inches of water is applied during the growing season and post-harvest. Post-harvest irrigations are essential, especially for early harvested varieties, through mid October. No assumption is made about effective rainfall. Frost damage can occur, but not on a regular basis. If protection is needed the ground is irrigated.

Orchard Floor Management. Weeds are controlled in the first two years by four annual cultivations in the row centers, one dormant strip spray applied in either fall, winter, or spring, and one foliar-applied herbicide for spot spraying persistent weeds. Since the strip spray is applied only to a narrow portion along the tree rows it is effectively used on $25 \%$ of the total acreage. The strip spray is applied at half rate in the first year and at the full rate thereafter. Beginning the second year, the spring spot spray is applied twice to cleans up weeds missed by the dormant strip spray in the tree row. A preharvest weed control spray is applied starting in the third year to clean up the orchard floor in preparation for harvest.

Beginning the third year mowing is used to manage the resident vegetation. Row middles are mowed seven times to control vegetation on the orchard floor up to the preharvest herbicide application.

Insect, Mite, and Disease Management. The management of almond pests and diseases occurs at different times during the year. This study refers to the months that certain pest sprays are applied, but the actual timing of theses control sprays is determined by the tree growth or life cycle of the pest. Some of the typical flowering stages mentioned are pink bud, popcorn, and full bloom. Refer to the publication UC Integrated Pest Management for Almonds or the Almond Production Manual for further information.

The first two year's pest and disease sprays are applied by a sprayer with a handgun instead of with an airblast sprayer due to the small size of the trees. Starting in the third year these materials are sprayed using an airblast sprayer.

Worms and mite control in the first year includes a single dormant spray applied with a sprayer. The dormant spray includes oil and an insecticide to control peach twig borer (PTB), San Jose scale (SJS), and early season mites. An in-season spray is also made the first year for worms and late in the growing season for mites. The application rates increase during the establishment years from $25 \%$ of full rate the first year to $50 \%$ in the second, $75 \%$ in the third, and $100 \%$ from the fourth year on. Ants become a problem when nuts are produced. Treatment for ants begins in the third year with an insecticide application.

In the third year a fungicide is applied during pink bud stage to prevent brown rot and shot hole. Zinc is added for nutritional needs. The shothole/nutrient spray is applied at $25 \%$ of full rate the second year, $50 \%$ in the third year, and full rate beginning the fourth.

Vertebrate Pest Management. Gophers can cause major losses to trees. Gophers are managed with the use of poison bait applied in the spring by a mechanical bait applicator. Ground squirrels are managed by late winter fumigation and the use of anti-coagulant bait in above-ground bait stations during the growing season.

Establishment Cost. The establishment cost is the sum of cash costs for land preparation, planting, trees, production expenses, and cash overhead for growing almond trees through the first year nuts are harvested minus any returns from production. The Total Accumulated Net Cash Cost in the third year shown in Table 1, represents the establishment cost per acre. For this study, the cost is $\$ 3,365$ per acre or $\$ 345,325$ for the 95 acres planted to almonds. Establishment cost is amortized over the remaining 22 years that the orchard is assumed to be in production. Establishment cost is used to determine the non-cash overhead, orchard capital recovery expense for production years. 


\section{Production Cultural Practices and Material Inputs}

Winter Sanitation. Winter sanitation practices includes removal of the mummy nuts from the trees and their destruction. This reduces overwintering sites for navel orangeworm. Operations for sanitation include; knocking the mummy nuts off the tree with a shaker, moving the nuts into the row middles with a sweeper and shredding the mummies. Winter sanitation operations are custom hired from December through January. Hand polling may be needed in low rainfall years.

Pruning. In this study, pruning is done from October through early December before heavy rainfall with hand crews. Prunings are stacked in the center of the row middles and bucked (pushed) out of the orchard by a tractor with a brush rake and burned or otherwise disposed of. Bucking and disposal are done during the winter months.

Pollination. Pollination is one of the most important cultural practices required for good nut set. Having strong, healthy hives in the orchard during bloom increases the probability of higher yields. Two and one half hives (each hive should have $5+$ frames of bees) per acre are contracted for pollination and are set in the orchard by the beekeeper before bloom starts. All hives should be moved out of the orchard before insecticide spraying occurs to avoid any contact between pesticides and bees.

Fertilization. Tree nitrogen status is determined by leaf analysis; sampling for analysis is done in June. Half of the nitrogen is applied by early spring after leaves have emerged to aid shoot development. The remaining 110 pounds of $\mathrm{N}$ per acre is added in late spring or summer. A liquid fertilizer is used as the nitrogen source. Potassium is applied in October in a band along the tree rows at two pounds per tree.

Orchard Floor Management. There are many different and acceptable ways of controlling weeds and ground floor management. In this study, the raised berms are treated differently from the orchard middles. One dormant strip spray of pre-emergent and post emergent herbicides to control weeds in the tree rows can be applied after the first significant winter rain. Weed control continues with two monthly post emergent spot sprays on the berms and, where needed, to control perennial weeds. Resident species are allowed to grow and become ground cover in the centers, between the tree rows. Row middles are mowed seven times to control resident vegetation during spring and summer. Frost damage can increase due to cooling effect caused by ground covers on orchard temperature. Injury to the almond buds can be mitigated by keeping the orchard vegetation mowed low during the bloom period. Mowing the orchard floor will reduce the number of blossoms which compete with almond blossoms for bee visitation. A preharvest weed control spray is used to prepare the orchard floor for harvest.

Insect and Mite Management. Pest control is achieved by a variety of management techniques. Insect and mite management begins with a dormant spray for control of PTB, SJS, and certain mite eggs. The dormant spray of horticultural oil and insecticide is made before bud swell during December and January. An in-season spray is needed for ants prior to harvest in June and July. At the beginning of hull split, an in-season spray mix to "control NOW and various mites is applied. NOW is also managed by early and timely harvest and winter sanitation. If harvest occurs too early green nuts may be picked up which can lead to postharvest problems. 
Disease Management. Control of bloom and foliar disease problems becomes more critical at maturity. Brown rot and shothole are the two main diseases, but more diseases are causing damage. Three applications of fungicides are made for control of diseases. These sprays are timed for pink bud, full bloom, or petal fall and after petal fall, but before a rain. Fungicide treatments are often mixed with zinc nutrient sprays.

Vertebrate Pest Management. Gophers are managed with the use of poison bait applied in the spring by a mechanical applicator. Ground squirrels are managed by late winter fumigation and/or the use of anticoagulant baits on above ground bait stations during the growing season when rodents accept grain.

Pesticide Recommendations. For specific pesticides choices and rates consult the publication UC IPM Pest Management Guidelines, Almonds. Cultural practices are discussed in the publication Integrated Pest Management for Almonds. Written recommendations are required for pesticides and are made by licensed pest control advisors. For information and pesticide use permits, contact the local county Agricultural Commissioner's office.

Harvest. Harvest starts in the third year after the orchard is planted. Yield maturity is reached in the seventh year. In this cost study the grower contracts to have the almond crop harvested. All of the harvest operations are done mechanically except for raking. If needed, hand raking, also known as check raking, moves nuts that were missed by the sweeper into the windrows. Harvest begins with the early maturing varieties in August and continues into October for pollenizers and other late maturing varieties.

For growers who own harvesting equipment, the equipment used for harvesting operations should be added to the equipment and investment inventories on Table 5 and custom harvest charges should be replaced in Harvest costs in Tables 1 and 2, with grower performed harvest and hauling costs.

Assessment. The Almond Board of California (ABC) assesses all almonds commercially grown in the state to pay for almond promotions and research. The mandatory assessment is paid by processors and is not reflected in grower costs.

Yields and Returns. Almonds begin bearing an economic crop in the third year after planting. Typical annual yields for almonds are measured in meat pounds per acre and are shown in Table C. Yields are from the third year of orchard establishment to maturity. An estimated price of a $\$ 1.40$ per pound of almonds is used in this study to determine potential profits/losses. Returns, shown in Table 7 , will vary and the yields and prices used in this cost study are estimates taking into consideration current situations.

\begin{tabular}{cc} 
Table C. & Annual yield per acre \\
\hline Year & Pounds of Nut Meats \\
3 & 400 \\
4 & 800 \\
5 & 1,600 \\
6 & 1,800 \\
$7+$ & 2,000 \\
\hline
\end{tabular}

Risk. The risks associated with producing and marketing almonds should not be minimized. While this study makes every effort to model a production system based on typical, real world practices, it cannot fully represent financial, agronomic and market risks which affect the profitability and economic viability of almond production. A market channel should be determined before almond orchards are planted and brought into production. 
Cash Overhead. Cash overhead consists of various cash expenses paid out during the year that are assigned to the whole farm and not to a particular operation. These costs include property taxes, interest on operating capital, office expense, liability and property insurance, sanitation services, and equipment repairs.

Property Taxes Counties charge a base property tax rate of $1 \%$ on the assessed value of the property. In some counties special assessment districts exist and charge additional taxes on property including equipment, buildings, and improvements. For this study, county taxes are calculated as $1 \%$ of the average value of the property. Average value equals new cost plus salvage value divided by 2 on a per acre basis. Salvage value for investments will vary.

Interest On Operating Capital Interest on operating capital is based on cash operating costs and is calculated monthly until harvest at a nominal rate of $10.46 \%$ per year. A nominal interest rate is the going market cost of borrowed funds.

Insurance Insurance for farm investments vary depending on the assets included and the amount of coverage. Property insurance provides coverage for property loss and is charged at $0.713 \%$ of the average value of the assets over their useful life. Liability insurance covers accidents on the farm and costs $\$ 455$ for the entire farm.

Office Expense Office and business expenses are estimated at $\$ 40$ per acre. These expenses include office supplies, telephones, bookkeeping, accounting, legal fees, road maintenance, etc.

Sanitation Services Sanitation services provide portable toilets for the orchard and cost the farm $\$ 327$ annually. This cost includes delivery and servicing of toilets. Cash overhead costs are included in Tables 1-5.

Non-Cash Overhead. Non-cash overhead is calculated as the capital recovery cost for equipment and other farm investments. Although farm equipment on almond orchards in the Northern San Joaquin Valley might be purchased new or used, this study shows the current purchase price for new equipment. The new purchase price is adjusted to $60 \%$ to indicate a mix of new and used equipment. Annual ownership costs (Equipment and Investments) are shown in Tables 1-3, and 5. They represent the capital recovery cost for,investments on an annual per acre basis.

Capital Recovery Costs. Capital recovery cost is the annual depreciation and interest costs for a capital investment. It is the amount of money required each year to recover the difference between the purchase price and salvage value (unrecovered capital). Put another way, it is equivalent to the annual payment on a loan for the irvestment with the downpayment equal to the discounted salvage value. This is a more complex method of calculating ownership costs than straight-line depreciation and opportunity costs, but more accurately represents the annual costs of ownership because it takes the time value of money into account (Boehlje and Eidman).

The calculation for annual capital recovery costs is as follows.

$$
\left[\left(\begin{array}{c}
\text { Purchase } \left.-\begin{array}{c}
\text { Salvage } \\
\text { Price }
\end{array}\right) \times\left(\begin{array}{c}
\text { Capital } \\
\text { Recovery } \\
\text { Factor }
\end{array}\right)
\end{array}\right)+\left[\begin{array}{cc}
\text { Salvage } & \times \text { Interest } \\
\text { Value } & \text { Rate }
\end{array}\right]\right.
$$

Salvage Value. Salvage value is an estimate of the remaining market value of an investment at the end of its useful life. It is calculated differently for different investments. For farm machinery (e.g., tractors and implements) the remaining value is a percentage of the new cost of the investment. Salvage value is calculated as

$$
\text { New Price } \times \text { \% Remaining Value }
$$


Salvage value for other investments including irrigation systems, buildings, and miscellaneous equipment is zero. The salvage value for land is equal to the purchase price because land does not depreciate from use. The purchase price and salvage value for certain equipment and investments are shown in Table 4.

Capital Recovery Factor. Capital recovery factor is the amortization factor or annual payment whose present value at compound interest is 1 . It is the function of the interest rate and years of life of the equipment.

Interest Rate. The interest rate of $7.81 \%$ used to calculate capital recovery cost is the USDA-ERS's ten year average of California's agricultural sector long-run rate of return to production assets from current income. It is used to reflect the long-term realized rate of return to these specialized resources that can only be used effectively in the agricultural sector. In other words, the next best alternative use for these resources is in another agricultural enterprise.

Equipment Cash Costs. Equipment costs are composed of three parts; non-cash overhead, cash overhead, and operating costs. Both of the overhead factors have been discussed in previous sections. The operating costs consist of fuel, lubrication, and repairs.

Repair costs are based on purchase price, annual hours of use, total hours of life, and repair coefficients formulated by the ASAE. Fuel and lubrication costs are also determined by ASAE equations based on maximum PTO hp, and type of fuel used. The fuel and repair cost per acre for each operation in Table 2 is determined by multiplying the total hourly operating cost in Table 6 for each piece of equipment used for the cultural practice by the number of hours per acre for that operation. Tractor time is $10 \%$ higher than implement time (Operation Time) for a given operation to account for fueling, moving equipment, and setup time. Prices for on-farm delivery of diesel and gasoline are $\$ 0.78$ and $\$ 1.22$ per gallon, respectively.

Acknowledgment. Appreciation is expressed to those growers and other cooperators who provided support for this study. 


\section{REFERENCES}

American Society of Agricultural Engineers. 1994. American Society of Agricultural Engineers Standards Yearbook. Russell H. Hahn and Evelyn E. Rosentreter (ed.) St. Joseph, Missouri. 41st edition.

Boelje, Michael D., and Vernon R. Eidman. 1984. Farm Management. John Wiley and Sons. New York, New York

Integrated Pest Management Education and Publications. 1990. U.C. Pest Management Guidelines, Almonds. In M. L. Flint (ed.) UC IPM pest management guidelines. University of California. Division of Agriculture and Natural Resources. Oakland, California. Publication 3339.

University of California, Division of Agriculture and Natural Resources. 1992. Grape Pest Management. Donald L. Flaherty, et. Al. (ed.) Second Edition. University of California, Division of Agriculture and Natural Resources. Oakland, California. Publication 3343.

University of California, Division of Agriculture and Natural Resources. 1996. Almond Production Manual. University of California, Division of Agriculture and Natural Resources. Oakland, California. Publication 3364 .

University of California, Division of Agriculture and Natural Resources. 1985. Integrated Peșt Management for Almonds. University of California, Division of Agriculture and Natural Resources. Oakland, California. Publication 3308.

For information concerning the above mentioned University of California publications contact UC DANR Communications Services (1-800-994-8849) or your local county Cooperative Extension office. 


\begin{tabular}{|c|c|c|c|c|c|c|}
\hline \multirow[b]{2}{*}{ Year } & \multicolumn{6}{|c|}{ Cost Per Acre } \\
\hline & 1st & 2nd & $3 r d$ & 4 th & 5 th & 6 th \\
\hline Meat Pounds Per Acre & & & 400 & 800 & 1,600 & 1,800 \\
\hline \multicolumn{7}{|l|}{ Planting Costs: } \\
\hline Land Preparation - Laser Level & $\$ 75$ & & & & & \\
\hline Land Preparation - Backhoe Tree Holes & 242 & & & & & \\
\hline Land Preparation - Fumigate & 492 & & & & & \\
\hline Land Preparation - Disc \& Float $2 \mathrm{X}$ & 17 & & & & & \\
\hline Land Preparation - Put Up Borders & 12 & & & & & \\
\hline Survey and Plant Trees & 83 & $\$ 9$ & $\$ 4$ & & & \\
\hline Trees: 110 Per Acre ( $1 \%$ Replant In 2nd Year) & 479 & 2 & 1 & & & \\
\hline Paint And Put Trunk Guards Trees & 22 & 1 & & & & \\
\hline TOTAL PLANTING COSTS & 1,422 & 11 & 5 & & & \\
\hline \multicolumn{7}{|l|}{ Cultural Costs: } \\
\hline Training, Pruning, \& Suckering & 39 & 29 & 43 & $\$ 100$ & $\$ 100$ & $\$ 100$ \\
\hline Stack Brush & & & 12 & 12 & 12 & 12 \\
\hline Buck Brush & & & 5 & 5 & 5 & 5 \\
\hline Burn Brush & & & 2 & 2 & 2 & 2 \\
\hline \multicolumn{7}{|l|}{ Winter Sanitation: } \\
\hline Knock Mummies & & & & 61 & 61 & 61 \\
\hline Blow \& Rake Mummies & & & & 47 & 47 & 47 \\
\hline Shred Mummies & & & & 7 & 7 & 7 \\
\hline Weed Control - Dormant Strip & 36 & 66 & 66 & 66 & 66 & 66 \\
\hline Insect Control - Dormant & & 52 & 66 & 66 & 66 & 66 \\
\hline Disease Control - Shothole/Nutrient & & 25 & 42 & 73 & 73 & 73 \\
\hline Insect Control - Pinkbud & & & 39 & 39 & 39 & 39 \\
\hline Pollination & & & 40 & 80 & 100 & 100 \\
\hline Fertilizer - Potassium & & & 18 & 33 & 36 & 41 \\
\hline Vertebrate Control - Rodents & 21 & 21 & 21 & 21 & 21 & 21 \\
\hline Fertilizer - Nitrogen & 34 & 45 & 77 & 82 & 94 & 109 \\
\hline Weed Control - Cultivate $4 \mathrm{X}$ & 17 & 17 & & & & \\
\hline Weed Control - Mow 7X & & & 51 & 51 & 51 & 51 \\
\hline Irrigate $7 \mathrm{X}$ & 61 & 61 & 61 & 61 & 61 & 61 \\
\hline Weed Control - Spot Spray Tree Rows $2 \mathrm{X}$ & 16 & 21 & 21 & 21 & 21 & 21 \\
\hline Insect Control - Ants $2 \mathrm{x}$ & & & 21 & 21 & 21 & 21 \\
\hline Insect Control - Worms \& Mites & 26 & 51 & 70 & 90 & 90 & 90 \\
\hline Weed Control - Preharvest Spray & & & 16 & 16 & 16 & 16 \\
\hline Miscellaneous Labor & 27 & 27 & 27 & 27 & 27 & 27 \\
\hline Pickup Truck Use & 54 & 54 & 54 & 54 & 54 & 54 \\
\hline ATV Truck Use & 45 & 45 & 45 & 45 & 45 & 45 \\
\hline Leaf Analysis & 1 & 1 & 1 & 1 & 1 & 1 \\
\hline
\end{tabular}




\begin{tabular}{|c|c|c|c|c|c|c|}
\hline \multirow{2}{*}{ Year } & \multicolumn{6}{|c|}{ Cost Per Acre } \\
\hline & $1 \mathrm{st}$ & 2nd & $3 r d$ & 4 th & 5 th & 6 th \\
\hline Meat Pounds Per Acre & & & 400 & 800 & 1,600 & 1,800 \\
\hline $\begin{array}{l}\text { TOTAL CULTURAL COSTS } \\
\text { Harvest Costs: }\end{array}$ & 377 & 515 & 798 & 1,081 & 1,116 & 1,136 \\
\hline Pole Trees & & & 21 & 12 & 13 & 13 \\
\hline Shake Trees & & & & 61 & 61 & 61 \\
\hline Sweep Nuts & & & & 45 & 45 & 45 \\
\hline Hand Rake & & & 21 & 2 & 2 & 2 \\
\hline Pick Up and Haul & & & 56 & 58 & 61 & 63 \\
\hline Hull Nuts & & & 13 & 25 & 60 & 80 \\
\hline TOTAL HARVEST COSTS & & & 111 & 203 & 242 & 264 \\
\hline Interest On Operating Capital a $10.46 \%$ & 63 & 19 & 45 & 63 & 69 & 70 \\
\hline TOTAL OPERATING COSTS/ACRE & 1,862 & 545 & 959 & 1,347 & 1,427 & 1,470 \\
\hline \multicolumn{7}{|l|}{ Cash Overhead Costs: } \\
\hline Office Expense & 105 & 105 & 105 & 105 & 105 & 105 \\
\hline Liability Insurance & 5 & 5 & 5 & 5 & 5 & 5 \\
\hline Sanitation Fees & 3 & 3 & 3 & 3 & 3 & 3 \\
\hline Property Taxes & 87 & 87 & 88 & 88 & 88 & 88 \\
\hline Property Insurance & 62 & 62 & 63 & 63 & 63 & 63 \\
\hline Investment Repairs & 21 & 21 & 21 & 21 & 21 & 21 \\
\hline TOTAL CASH OVERHEAD COSTS & 283 & 283 & 285 & 285 & 285 & 285 \\
\hline TOTAL CASH COSTS/ACRE & 2,145 & 828 & 1,244 & 1,632 & 1,712 & 1,755 \\
\hline INCOME/ACRE FROM PRODUCTION & & & 560 & 1,120 & 2,240 & 2,520 \\
\hline NET CASH COSTS/ACRE FOR THE YEAR & 2,145 & 828 & 684 & 512 & & \\
\hline PROFIT/ACRE ABOVE CASH COSTS & & & & & 528 & 765 \\
\hline ACCUMULATED NET CASH COSTS/ACRE & 2,145 & 2,973 & 3,657 & 4,169 & 3,641 & 2,876 \\
\hline \multicolumn{7}{|l|}{ Non-Cash Overhead Costs: } \\
\hline \multicolumn{7}{|l|}{ Capital Recovery Cost: } \\
\hline Shop Building & 41 & 41 & 41 & 41 & 41 & 41 \\
\hline Land a $\$ 7,500 /$ Acre & 617 & 617 & 617 & 617 & 617 & 617 \\
\hline Fuel Tank \& Pump & 7 & 7 & 7 & 7 & 7 & 7 \\
\hline Shop Tools & 13 & 13 & 13 & 13 & 13 & 13 \\
\hline Flood Irrigation System & 42 & 42 & 42 & 42 & 42 & 42 \\
\hline Pruning Equipment & 2 & 2 & 2 & 2 & 2 & 2 \\
\hline Equipment & 58 & 52 & 73 & 69 & 69 & 54 \\
\hline TOTAL NON-CASH OVERHEAD COST/ACRE & 780 & 774 & 795 & 791 & 791 & 776 \\
\hline TOTAL COST/ACRE FOR THE YEAR & 2,925 & 1,602 & 2,039 & 2,423 & 2,503 & 2,531 \\
\hline INCOME/ACRE FROM PRODUCTION & & & 560 & 1,120 & 2,240 & 2,520 \\
\hline TOTAL NET COST/ACRE FOR THE YEAR & 2,925 & 1,602 & 1,479 & 1,303 & 263 & 11 \\
\hline \multicolumn{7}{|l|}{ NET PROFIT/ACRE ABOVE TOTAL COST } \\
\hline TOTAL ACCUMULATED NET COST/ACRE & 2,925 & 4.527 & 6,006 & 7,309 & 7,572 & 7,583 \\
\hline
\end{tabular}

1998 North San Joaquin Valley Almond Cost Study - Flood Irrigated $84 \quad$ UC Cooperative Extension 
Labor Rate: \$11.73/hr. machine labor $\$ 7.71 / \mathrm{hr}$. non-machine labor
Operating Capital Interest Rate: 10.00\%

Yield per Acre: 2000 bi

\begin{tabular}{|c|c|c|c|c|c|c|c|}
\hline & Operation & ---- & 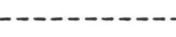 & $h$ and Labc & $S$ per $A c r$ & ---- & --- \\
\hline & Time & Labor & Fuel, Lube & Material & Custom/ & Total & Your \\
\hline Operation & ( $\mathrm{Hrs} / \mathrm{A})$ & Cost & \& Repairs & Cost & Rent & Cost & Cost \\
\hline
\end{tabular}

Cultural:

Prune, Train, \& Sucker

Stack Brush

Buck Brush

Burn Brush

13.00

1.50

Winter Sanitation:

- Knock Mummies

- Blow and Rake Mummies

- Shred Murmies

Weed Control - Winter Strip

Pest Control - Dormant

Pest Control - Shothole/Nutrient

Pest Control - Pinkbud

Pollination

Fertilize - Potassium Sulfate

Pest Control - Gopher \& Squirrel

Fertilize N - 220 Lbs N/Acre

Weed Control - Mow 7X

Irrigate $7 \mathrm{X}$

Weed Control - Spot Spray $2 \mathrm{X}$

Pest Control - Ants 2X

Pest Control - Worm/Mite

Weed Control - Preharvest Spray

Miscellaneous - Other Costs

Pickup Truck Use

ATV Use

Leaf Analysis

TOTAL CULTURAL COSTS
0.30

0.00

0.25

0.33

0.30

0.33

0.33

0.33

0.00

0.00

1.00

0.80

2.33

2.25

0.60

0.60

0.29

0.30

2.00

2.85

2.85

0.00

32.85

100
12
4
2

0

0
2

2
5

4
5

5

5

5
0

0

8

8

11

33

17
8

8

4

4

15

40

40

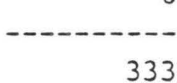

333

0

$\begin{array}{lll}0 & 0 & 100 \\ 0 & 0 & 12 \\ 0 & 0 & 0\end{array}$

100

(n)

0

61

0

0

61

3

45

45

$\begin{array}{ll}2 & 60 \\ 1 & 53\end{array}$

153

$\begin{array}{lr}1 & 27 \\ 0 & 0\end{array}$

$0 \quad 0$

0

2

18

3

2

1

13

4
0

53

600

149

49 
Table 2. CONTINUED

U C COOPERATIVE EXTENSION

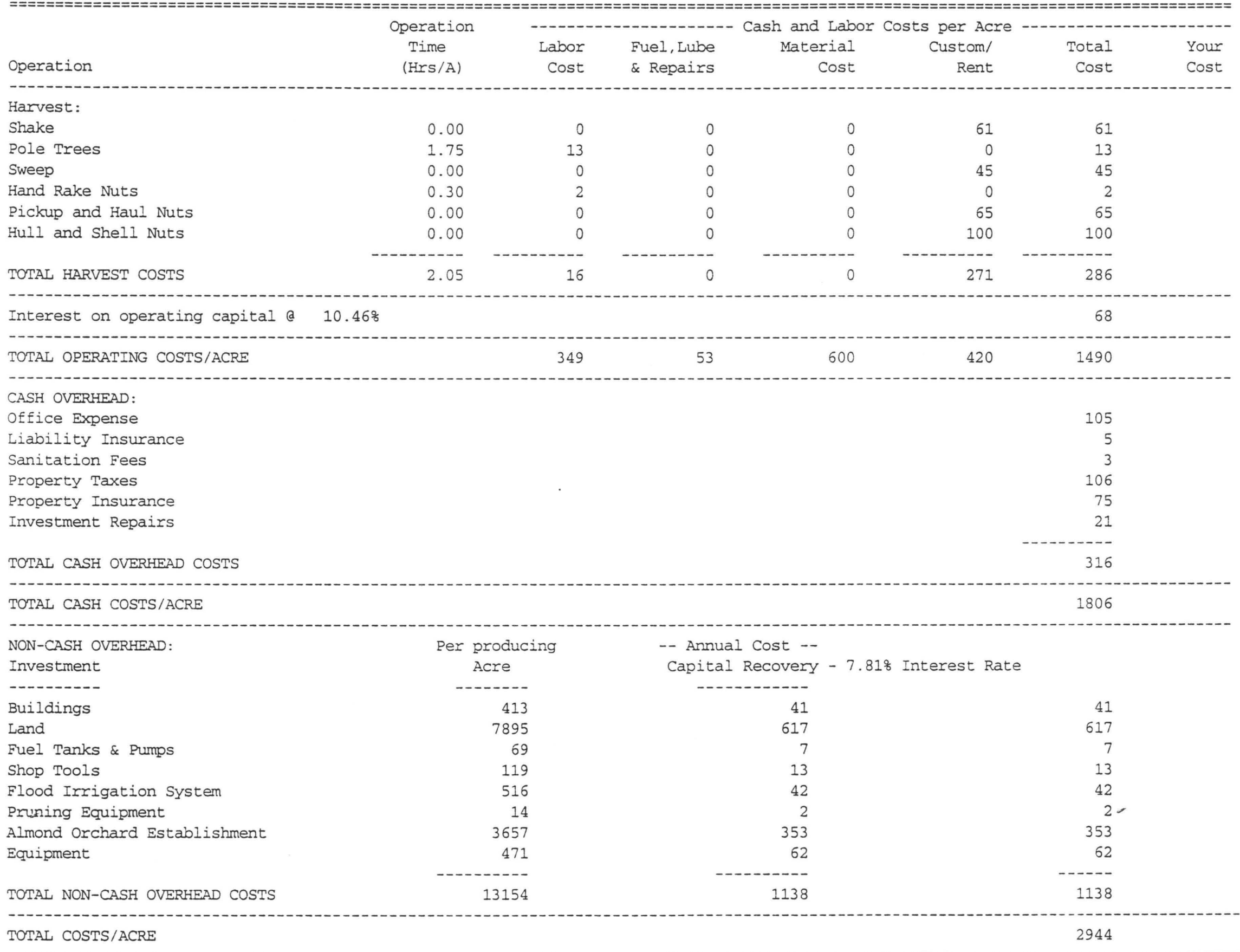

TOTAL COSTS/ACRE

1998 North San Joaquin Valley Almond Cost Study - Flood Irrigated 86 UC Cooperative Extension 
NORTHERN SAN JOAQUIN VALLEY - 1998

$$
\text { FLOOD IRRIGATION }
$$

\begin{tabular}{|c|c|c|c|c|c|}
\hline & Quantity/Acre & Unit & $\begin{array}{l}\text { Price or } \\
\text { Cost/Unit }\end{array}$ & $\begin{array}{l}\text { Value or } \\
\text { Cost/Acre }\end{array}$ & $\begin{array}{l}\text { Your } \\
\text { Cost }\end{array}$ \\
\hline \multicolumn{6}{|c|}{ GROSS RETURNS } \\
\hline Almonds & 2000.00 & طن & 1.40 & 2800 & \\
\hline TOTAL GROS & FOR ALMOND & & & 2800 & \\
\hline
\end{tabular}

OPERATING COSTS

Winter Sanitation:

\begin{tabular}{|c|c|c|c|c|}
\hline Shake Trees & 110.00 & Tree & 0.55 & 61 \\
\hline Sweep Nuts & 1.00 & Acre & 45.00 & 45 \\
\hline \multicolumn{5}{|l|}{ erbicide: } \\
\hline Goal 2 XL & 2.00 & Pint & 14.48 & 29 \\
\hline Surflan 4 AS & 3.00 & Pint & 10.46 & 31 \\
\hline \multicolumn{5}{|l|}{ nsecticide: } \\
\hline Lorsban $4 \mathrm{E}$ & 7.00 & Pint & 7.40 & 52 \\
\hline \multicolumn{4}{|l|}{ ungicide: } & 21 \\
\hline Kocide & 8.00 & b & 2.99 & 24 \\
\hline Ziram WDG 76 & 8.00 & biا & 3.31 & 26 \\
\hline Rovral & 2.00 & ملا & 23.60 & 47 \\
\hline \multicolumn{5}{|l|}{ ent: } \\
\hline $\begin{array}{l}\text { Sprayer Rental } \\
\text { ertilizer: }\end{array}$ & 6.00 & Acre & 6.00 & 34 \\
\hline Neutral Zinc & 5.00 & طLL & 1.53 & 8 \\
\hline Potassium Sulfate & 220.00 & biL & 0.123 & 27 \\
\hline $\mathrm{UN}-32$ & 220.00 & bi N & 0.393 & 86 \\
\hline \multicolumn{5}{|l|}{ ontract: } \\
\hline $\begin{array}{l}\text { Pollination Fee } \\
\text { ustom: }\end{array}$ & 2.50 & Hive & 40.00 & 100 \\
\hline Ground Application & 3.00 & Acre & 4.75 & 14 \\
\hline Shake Trees & 110.00 & Tree & 0.55 & 61 \\
\hline Sweep Nuts & 1.00 & Acre & 45.00 & 45 \\
\hline Pickup Nuts & 1.00 & Acre & 55.00 & 55 \\
\hline Haul Nuts & 2000.00 & bu & 0.005 & 10 \\
\hline Hull \& Shell Nuts & 2000.00 & bلد & 0.05 & 100 \\
\hline $\begin{array}{l}\text { Leaf Analysis } \\
\text { odenticide: }\end{array}$ & 1.00 & Acre & 1.00 & 1 \\
\hline Gopher Bait & 1.50 & فـ & 3.76 & 6 \\
\hline Squirrel Bait & 1.50 & Lb & 4.82 & 7 \\
\hline
\end{tabular}

Squirrel Bait 


$\begin{array}{lrlrr}\text { Water - District } & 48.00 & \text { AcIn } & 0.903 & 43 \\ \begin{array}{l}\text { Acaracide: } \\ \text { Omite } 30 \mathrm{WP}\end{array} & 8.00 & \text { Lb } & 6.16 & 49 \\ \text { Miscellaneou: } & & & & \\ \text { Miscellaneous } & 1.00 & \text { Acre } & 12.00 & 12 \\ \text { Labor (machine) } & 15.06 & \text { Hrs } & 11.73 & 177 \\ \text { Labor (non-machine) } & 22.35 & \text { Hrs } & 7.71 & 172 \\ \text { Fuel - Gas } & 9.02 & \text { Gal } & 1.22 & 11 \\ \text { Fuel - Diesel } & 21.08 & \text { Gal } & 0.78 & 16 \\ \text { Lube } & & & & 22 \\ \text { Machinery repair } & & & & 68 \\ \text { Interest on operating capital @ } 10.46 \% & & & -1490\end{array}$

NET RETURNS ABOVE OPERATING COSTS 1310

CASH OVERHEAD COSTS:

Office Expense

Liability Insurance

Sanitation Fees

Property Taxes

Property Insurance

Investment Repairs

TOTAL CASH OVERHEAD COSTS/ACRE

316

TOTAL CASH COSTS/ACRE 1806

TOTAL CASH COSTS/ACRE

NON-CASH OVERHEAD COSTS (CAPITAL RECOVERY - $7.81 \%$ Interest Rate):

Buildings

Land

Fuel Tanks \& Pumps

41

Shop Tools

Flood Irrigation System

Pruning Equipment

Almond Orchard Establishment

Equipment

TOTAL NON-CASH OVERHEAD COSTS/ACRE

617

13

2

1138

TOTAL COSTS/ACRE 2944

NET RETURNS ABOVE TOTAL COSTS -144 
FLOOD IRRIGATION

\begin{tabular}{|c|c|c|c|c|c|c|c|c|c|c|c|c|c|}
\hline Beginning DEC 97 & $\mathrm{DEC}$ & JAN & FEB & MAR & APR & MAY & $\pi \mathrm{N}$ & JUL & AUG & SEP & $O C T$ & NOV & TOTAL \\
\hline Ending NOV 98 & 97 & 98 & 98 & 98 & 98 & 98 & 98 & 98 & 98 & 98 & 98 & 98 & \\
\hline \multicolumn{14}{|l|}{ Cultural: } \\
\hline Stack Brush & 12 & & & & & & & & & & & & 12 \\
\hline Buck Brush & 5 & & & & & & & & & & & & 5 \\
\hline Burn Brush & 2 & & & & & & & & & & & & 2 \\
\hline \multicolumn{14}{|l|}{ Winter Sanitation: } \\
\hline - Blow and Rake Mummies & 47 & & & & & & & & & & & & 47 \\
\hline - Shred Mummies & 7 & & & & & & & & & & & & 7 \\
\hline \multicolumn{14}{|l|}{ Weed Control } \\
\hline - Winter Strip & & 66 & & & & & & & & & & & 66 \\
\hline Pest Control - Dormant & & 33 & 33 & & & & & & & & & & 66 \\
\hline \multicolumn{14}{|l|}{ Pest Control } \\
\hline - Shothole/Nutrient & & & 73 & & & & & & & & & & $\begin{array}{l}73 \\
39\end{array}$ \\
\hline Pest Control - Pinkbud & & & 39 & & & & & & & & & & 39 \\
\hline - Potassium Sulfate & & & & 14 & 14 & 14 & & & & & & & 41 \\
\hline Pest Control & & & & & & & & & & & & & \\
\hline - Gopher \& Squirrel & & & & 9 & & & & & 11 & & & & 21 \\
\hline Fertilize N - 220 Lbs N/Acre & & & & & 76 & & & & & 33 & & & 109 \\
\hline Weed Control - Mow 7X & & & & & 7 & 7 & 7 & 7 & 15 & 7 & & & 51 \\
\hline Irrigate $7 \mathrm{x}$ & & & & & 9 & 9 & 17 & 17 & 9 & & & & 61 \\
\hline Weed Control - Spot Spray & & & & & 11 & & 11 & & & & & & 21 \\
\hline Pest Control - Ants $2 \mathrm{X}$ & & & & & & & 9 & 9 & & & & & 18 \\
\hline Pest Control - Worm/Mite & & & & & & & & 90 & & & & & 90 \\
\hline Weed Control - Preharvest & & & & & & & & & & 21 & & & 21 \\
\hline Miscellaneous - Other Costs & 3 & 3 & 3 & 3 & 3 & 3 & 3 & 3 & 3 & 3 & & & 27 \\
\hline Pickup Truck Use & 5 & 5 & 5 & 5 & 5 & 5 & 5 & 5 & 5 & 5 & & & 54 \\
\hline ATV Use & 4 & 4 & 4 & 4 & 4 & 4 & 4 & 4 & 4 & 4 & & & 44 \\
\hline Leaf Analysis & 1 & & & & & & & & & & & & 1 \\
\hline TOTAL CULTURAL COSTS & 247 & 111 & 257 & 36 & 129 & 42 & 56 & 136 & 47 & 74 & & & 1135 \\
\hline
\end{tabular}




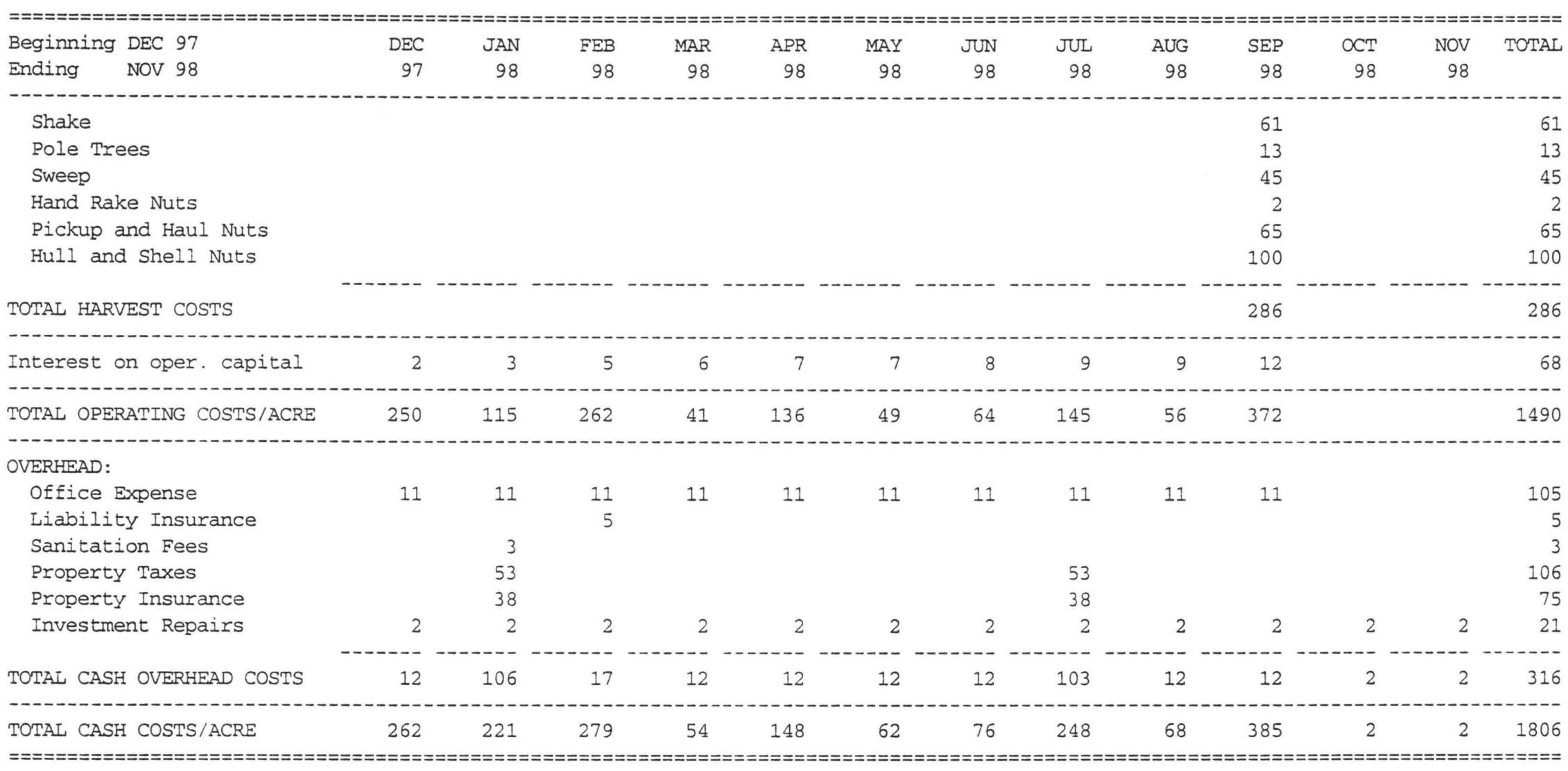


ANNUAL EQUIPMENT COSTS

\begin{tabular}{|c|c|c|c|c|c|c|c|}
\hline Description & Price & $\begin{array}{l}\text { Yrs } \\
\text { Life }\end{array}$ & $\begin{array}{l}\text { Salvage } \\
\text { Value } \\
\end{array}$ & $\begin{array}{l}\text { sh Overhead } \\
\text { Capital } \\
\text { Recovery }\end{array}$ & $\begin{array}{l}- \\
\text { Insur- } \\
\text { ance }\end{array}$ & Taxes & Total \\
\hline 9835 HP 4WD Tractor & 22737 & 15 & 4426 & 2460 & 97 & 136 & 2693 \\
\hline 9866 HP 2WD Tractor & 24882 & 15 & 4844 & 2692 & 106 & 149 & 2947 \\
\hline 98 ATV 4WD & 4219 & 7 & 1600 & 625 & 21 & 29 & 675 \\
\hline 98 Brush Rake - $10^{\prime}$ & 1584 & 25 & 45 & 145 & 6 & 8 & 159 \\
\hline 98 Front End Loader & 4852 & 15 & 466 & 543 & 19 & 27 & 588 \\
\hline 98 Mower - Flail 10' & 8380 & 10 & 1482 & 1135 & 35 & 49 & 1219 \\
\hline 98 Pickup - 1/2 Ton & 16500 & 7 & 1650 & 2963 & 65 & 91 & 3118 \\
\hline 98 Weed Sprayer - $100 \mathrm{Gal}$ & 3947 & 10 & 698 & 535 & 17 & 23 & 574 \\
\hline TOTAL & 87101 & & 15211 & 11098 & 365 & 512 & 11974 \\
\hline $60 \%$ of New Cost * & 52261 & & 9127 & 6659 & 219 & 307 & 7184 \\
\hline
\end{tabular}

* Used to reflect a mix of new and used equipment.

ANNUAL INVESTMENT COSTS

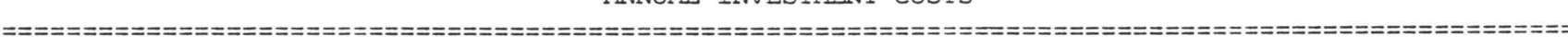

\begin{tabular}{|c|c|c|c|c|c|c|c|c|}
\hline Description & Price & $\begin{array}{l}\text { Yrs } \\
\text { Life }\end{array}$ & $\begin{array}{l}\text { Salvage } \\
\text { Value }\end{array}$ & $\begin{array}{l}\text { Capital } \\
\text { Recovery }\end{array}$ & $\begin{array}{l}\text { Insur- } \\
\text { ance }\end{array}$ & Taxes & Repairs & Total \\
\hline \multicolumn{9}{|l|}{ INVESTMENT } \\
\hline Buildings & 39253 & 20 & & 3942 & 140 & 196 & 785 & 5063 \\
\hline Flood Irrigation System & 49042 & 40 & & 4029 & 175 & 245 & 980 & 5429 \\
\hline Fuel Tanks \& Pumps & 6546 & 20 & & 657 & 23 & 33 & 131 & 844 \\
\hline Land & 750000 & 22 & 750000 & 58575 & 5348 & 7500 & 0 & 71422 \\
\hline Orchard Establishment & 347415 & 22 & & 33548 & 1239 & 1737 & 0 & 36523 \\
\hline Pruning Equipment & 1325 & 10 & 133 & 187 & 5 & 7 & 25 & 224 \\
\hline Shop Tools & 11330 & 15 & 1133 & 1266 & 44 & 62 & 113 & 1486 \\
\hline TOTAL INVESTMENT & 1204911 & & 751266 & 102203 & 6974 & 9781 & 2034 & 120992 \\
\hline
\end{tabular}

ANNUAL BUSINESS OVERHEAD COSTS

\begin{tabular}{|c|c|c|c|c|}
\hline & Unitś/ & & Price/ & Total \\
\hline Description & Farm & Unit & Unit & Cost \\
\hline Liability Insurance & 100.00 & Acre & 4.55 & 455 \\
\hline Office Expense & 100.00 & Acre & 100.00 & 10000 \\
\hline Sanitation Fees & 100.00 & Acre & 3.27 & 327 \\
\hline
\end{tabular}




\begin{tabular}{|c|c|c|c|c|c|c|c|c|}
\hline Yr Description & $\begin{array}{l}\text { Actual } \\
\text { Hours } \\
\text { Used }\end{array}$ & $\begin{array}{l}\text { Capital } \\
\text { Recovery }\end{array}$ & $\begin{array}{l}\text { Cash Ove } \\
\text { Insur- } \\
\text { ance }\end{array}$ & $\begin{array}{l}\text { head - } \\
\text { Taxes }\end{array}$ & $\begin{array}{l}\text { OSTS PER } \\
\text { Repairs }\end{array}$ & $\begin{array}{l}\text { UR ----- } \\
\text { erating } \\
\text { Fuel \& } \\
\text { Lube }\end{array}$ & $\begin{array}{l}\text { Total } \\
\text { Oper. }\end{array}$ & $\begin{array}{r}\text { Total } \\
\text { Costs/Hr }\end{array}$ \\
\hline $9835 \mathrm{HP}$ 4WD Tractor & 321.0 & 4.60 & 0.18 & 0.25 & 0.40 & 1.54 & 1.94 & 6.98 \\
\hline 9866 HP 2WD Tractor & 593.4 & 2.72 & 0.11 & 0.15 & 1.03 & 2.91 & 3.94 & 6.92 \\
\hline 98 ATV 4WD & 284.7 & 1.32 & 0.04 & 0.06 & 0.31 & 0.94 & 1.25 & 2.67 \\
\hline 98 Brush Rake - 10' & 36.5 & 2.39 & 0.10 & 0.13 & 0.21 & 0.00 & 0.21 & 2.83 \\
\hline 98 Front End Loader & 36.5 & 8.92 & 0.31 & 0.44 & 0.67 & 0.00 & 0.67 & 10.34 \\
\hline 98 Mower - Flail 10' & 189.5 & 3.59 & 0.11 & 0.16 & 3.40 & 0.00 & 3.40 & 7.26 \\
\hline 98 Pickup - 1/2 Ton & 284.7 & 6.24 & 0.14 & 0.19 & 1.20 & 3.51 & 4.71 & 11.28 \\
\hline 98 Weed Sprayer - $100 \mathrm{Gal}$ & 149.0 & 2.15 & 0.07 & 0.09 & 1.04 & 0.00 & 1.04 & 3.36 \\
\hline
\end{tabular}

Table 7 .

RANGING ANALYSIS

NORTHERN SAN JOAQUIN VALLEY - 1998 FLOOD IRRIGATION COSTS PER ACRE AT VARYING YIELDS TO PRODUCE ALMOND

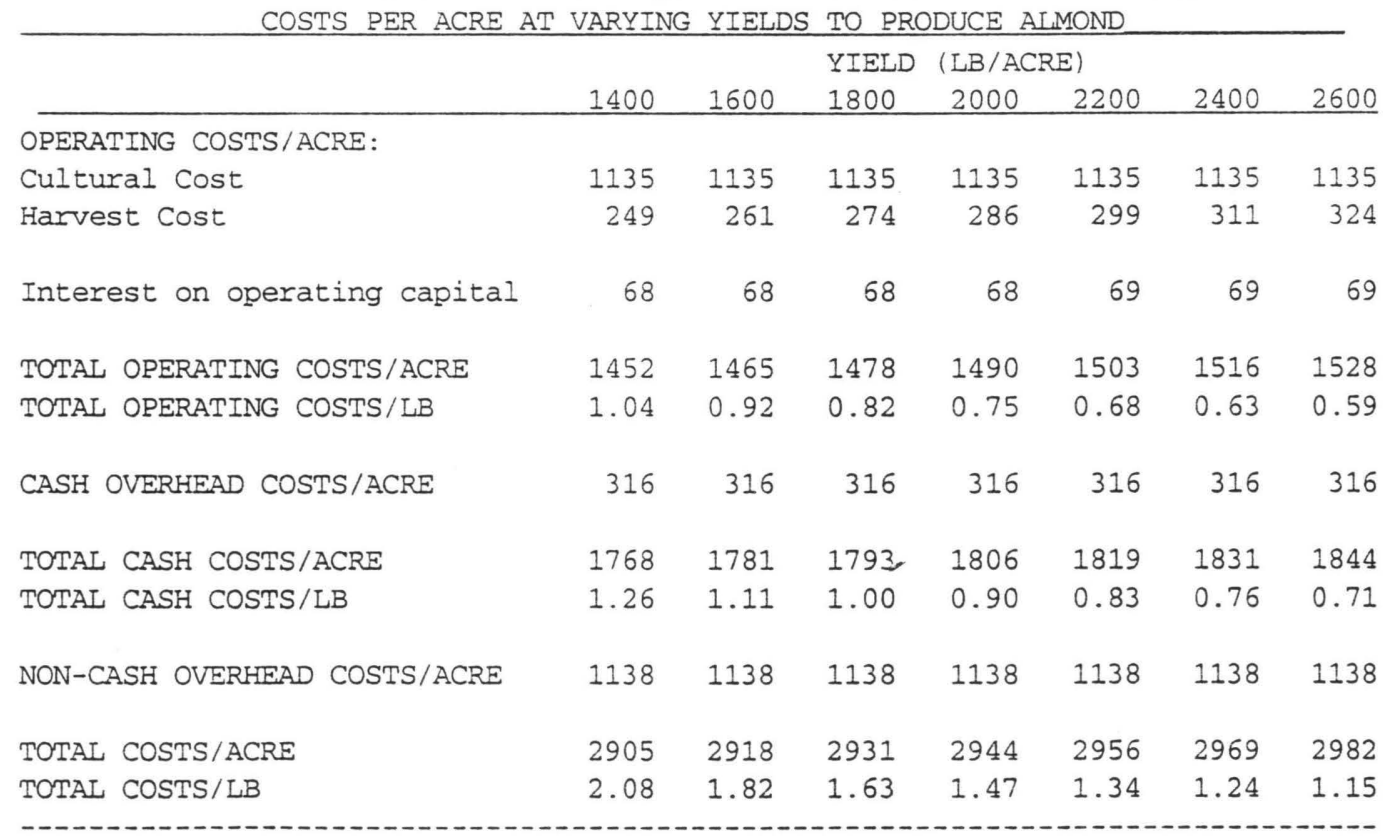


U C COOPERATIVE EXTENSTON

NET RETURNS PER ACRE ABOVE OPERATING COSTS FOR ALMOND

\begin{tabular}{|c|c|c|c|c|c|c|c|}
\hline $\begin{array}{c}\text { PRICE } \\
\text { (DOLLARS/LB) }\end{array}$ & & & & $\begin{array}{l}\text { IELD } \\
\text { (ACRE) }\end{array}$ & & & \\
\hline Almonds & 1400 & 1600 & 1800 & 2000 & 2200 & 2400 & 2600 \\
\hline 0.80 & -332 & -185 & -38 & 110 & 257 & 404 & 552 \\
\hline 1.00 & -52 & 135 & 322 & 510 & 697 & 884 & 1072 \\
\hline 1.20 & 228 & 455 & 682 & 910 & 1137 & 1364 & 1592 \\
\hline 1.40 & 508 & 775 & 1042 & 1310 & 1577 & 1844 & 2112 \\
\hline 1.60 & 788 & 1095 & 1402 & 1710 & 2017 & 2324 & 2632 \\
\hline 1.80 & 1068 & 1415 & 1762 & 2110 & 2457 & 2804 & 3152 \\
\hline 2.00 & 1348 & 1735 & 2122 & 2510 & 2897 & 3284 & 3672 \\
\hline
\end{tabular}

NET RETURNS PER ACRE ABOVE CASH COSTS FOR ALMOND

\begin{tabular}{|c|c|c|c|c|c|c|c|}
\hline $\begin{array}{c}\text { PRICE } \\
\text { (DOLLARS / LB) }\end{array}$ & \multicolumn{7}{|c|}{$\begin{array}{c}\text { YIELD } \\
\text { (LB/ACRE) }\end{array}$} \\
\hline Almonds & 1400 & 1600 & 1800 & 2000 & 2200 & 2400 & 2600 \\
\hline 0.80 & -648 & -501 & -353 & -206 & -59 & 89 & 236 \\
\hline 1.00 & -368 & -181 & 7 & 194 & 381 & 569 & 756 \\
\hline 1.20 & -88 & 139 & 367 & 594 & 821 & 1049 & 1276 \\
\hline 1.40 & 192 & 459 & 727 & 994 & 1261 & 1529 & 1796 \\
\hline 1.60 & 472 & 779 & 1087 & 1394 & 1701 & 2009 & 2316 \\
\hline 1.80 & 752 & 1099 & 1447 & 1794 & 2141 & 2489 & 2836 \\
\hline 2.00 & 1032 & 1419 & 1807 & 2194 & 2581 & 2969 & 3356 \\
\hline
\end{tabular}

NET RETURNS PER ACRE ABOVE TOTAL COSTS FOR ALMOND

\begin{tabular}{|c|c|c|c|c|c|c|c|}
\hline $\begin{array}{c}\text { PRICE } \\
\text { (DOLLARS/LB) }\end{array}$ & \multicolumn{7}{|c|}{$\begin{array}{c}\text { YIELD } \\
\text { (LB/ACRE) }\end{array}$} \\
\hline Almonds & 1400 & 1600 & 1800 & 2000 & 2200 & 2400 & 2600 \\
\hline 0.80 & -1785 & -1638 & -1491 & -1344 & -1196 & -1049 & -902 \\
\hline 1.00 & -1505 & -1318 & -1131 & -944 & -756 & -569 & -382 \\
\hline 1.20 & -1225 & -998 & -771 & -544 & -316 & -89 & 138 \\
\hline 1.40 & -945 & -678 & -411 & -144 & 124 & 391 & 658 \\
\hline 1.60 & -665 & -358 & -51 & 256 & 564 & 871 & 1178 \\
\hline 1.80 & -385 & -38 & 309 & 656 & 1004 & 1351 & 1698 \\
\hline 2.00 & -105 & 282 & 669 & 1056 & 1444 & 1831 & 2218 \\
\hline
\end{tabular}

1998 North San Joaquin Valley Almond Cost Study - Flood Irrigated 93 UC Cooperative Extension 
COSTS AND RETURNS - PER ACRE BASIS

\begin{tabular}{|c|c|c|c|c|c|c|c|}
\hline Crop & $\begin{array}{l}\text { 1. Gross } \\
\text { Returns }\end{array}$ & $\begin{array}{r}\text { 2. Operating } \\
\text { Costs }\end{array}$ & $\begin{array}{l}\text { 3. Net Returns } \\
\text { Above Oper. } \\
\text { Costs }(1-2)\end{array}$ & $\begin{array}{l}\text { 4. Cash } \\
\text { Costs }\end{array}$ & $\begin{array}{l}\text { 5. Net Returns } \\
\text { Above Cash } \\
\text { Costs (1-4) }\end{array}$ & $\begin{array}{l}\text { 6. Total } \\
\text { Costs }\end{array}$ & $\begin{array}{l}\text { 7. Net Returns } \\
\text { Above Total } \\
\text { Costs }(1-6)\end{array}$ \\
\hline Almonds & 2800 & 1490 & 1310 & 1806 & 994 & 2944 & -144 \\
\hline
\end{tabular}

COSTS AND RETURNS - TOTAL ACREAGE

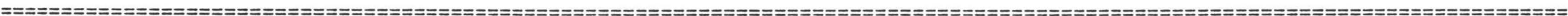

\begin{tabular}{|c|c|c|c|c|c|c|c|}
\hline Crop & $\begin{array}{l}\text { 1. Gross } \\
\text { Retums }\end{array}$ & $\begin{array}{l}\text { 2. Operating } \\
\text { Costs }\end{array}$ & $\begin{array}{l}\text { 3. Net Returns } \\
\text { Above Oper. } \\
\text { Costs (1-2) }\end{array}$ & $\begin{array}{l}\text { 4. Cash } \\
\text { Costs }\end{array}$ & $\begin{array}{l}\text { 5. Net Returns } \\
\text { Above Cash } \\
\text { Costs }(1-4)\end{array}$ & $\begin{array}{l}\text { 6. Total } \\
\text { Costs }\end{array}$ & $\begin{array}{l}\text { 7. Net Returns } \\
\text { Above Total } \\
\text { Costs }(1-6)\end{array}$ \\
\hline Almonds & 154000 & 81963 & 72037 & 99331 & 54669 & 161896 & -7896 \\
\hline
\end{tabular}

BREAKEVEN PRICES PER YIELD UNIT

\begin{tabular}{|c|c|c|c|c|c|}
\hline CROP & $\begin{array}{l}\text { Base Yield } \\
\text { (Units/Acre) }\end{array}$ & $\begin{array}{l}\text { Yield } \\
\text { Units }\end{array}$ & $\begin{array}{r}\text { Operating } \\
\text { Costs }\end{array}$ & $\begin{array}{l}\text { rice To } \\
\text { Cash } \\
\text { Costs }\end{array}$ & $\begin{array}{l}\text { Total } \\
\text { Costs }\end{array}$ \\
\hline & & & - - - - - & ield Un & \\
\hline Almonds & 2000.0 & $\mathrm{Lb}$ & 0.75 & 0.90 & 1.47 \\
\hline
\end{tabular}

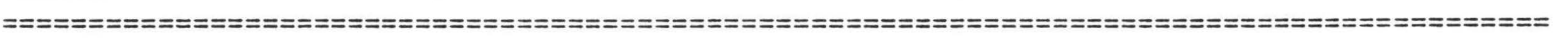

BREAKEVEN YIELDS PER ACRE

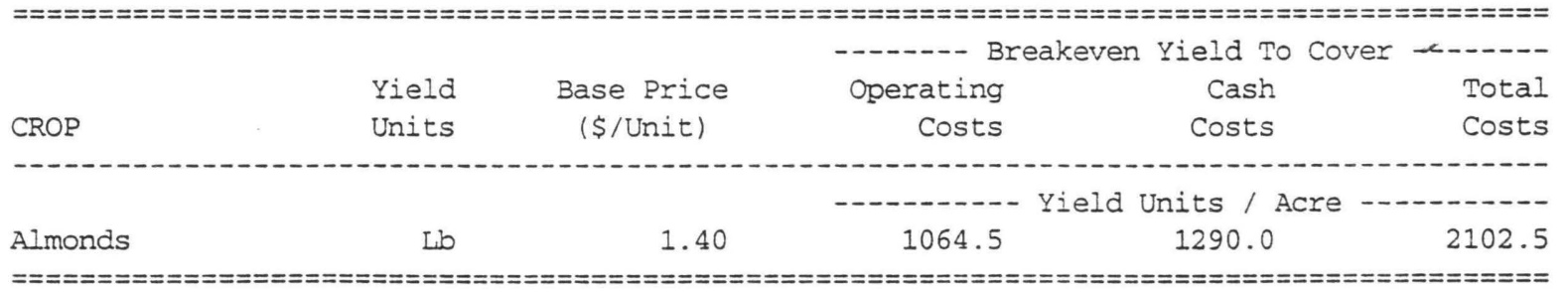




\section{Appendix 7}

New grape production systems 


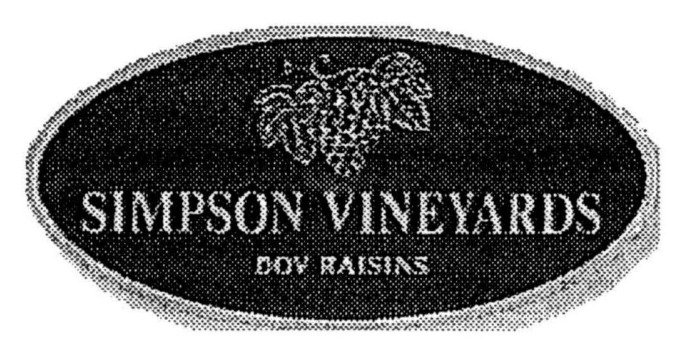

\title{
THE SIMPSON DOV RAISIN PRODUCTION SYSTEM:
}

\author{
DEVELOPMENT AND COMMERCIAL APPLICATION
}

\author{
L. Simpson*, D. Delaney*, G.T. Berg**, and R.K. Striegler**
}

\begin{abstract}
*Owner and Vineyard Manager, respectively, Simpson Vineyards, 6708 Road 26, Madera, CA 93637 USA ** Research Associate and Julio R. Gallo Director's Chair, respectively. Viticulture and Enology Research Center, California State University, Fresno, Fresno, CA 93740-8003 USA
\end{abstract}

Introduction

The production of traditional dried-on-the-ground raisins is a very expensive and labor intensive process (Klonsky, et al, -1997; Striegler, et al, 1996; Mamer and Wilkie, 1990). For the average raisin grower with a 2.0 ton per acre $[4.5 \mathrm{mt} / \mathrm{ha}]$ raisin yield, approximately 55 60 hours of seasonal labor are required to pick, turn, roll, retrieve, and box each acre of finished raisins [136-148 hrs/ha] (Mamer and Wilkie, 1990). Pre-harvest cultural practices consume approximately 25 additional labor hours [62 hrs/ha] from seasonal laborers, for a total seasonal labor requirement of approximately 80-85 hours per acre [198-210 hrs/ha]. When the harvest labor requirement alone is expanded to include all raisin growers in California, approximately 40,000 to 50,000 seasonal laborers are needed to complete the raisin harvest during the 4-5 week window in August and September each year (Alvarado, et al, 1992). Dormant season pruning also requires growers to seek sizable temporary labor crews to perform this task during the winter months. The supply and cost of labor, and the risk of crop damage or loss due to rain are two of the biggest concerns today's raisin growers are faced with.

The afore-mentioned factors have led to efforts to mechanize raisin harvest and handling (Berg, et al, 1996; Malcolm, 1993). In this paper, we describe the development and application of a commercially viable dried-on-the-vine (DOV) raisin production system. This system is known as the Simpson DOV Raisin Production System. This system has shown much promise and success while making efficient use of land, labor, capital, and management resources.

\section{Principles of DOV Raisin Production}

Research efforts on commercially applicable DOV raisin production systems were first attempted in the late 1950s and early 1960s in both Australia (May and Kerridge, 1967) and in California (Christensen, et al, 1970; Studer and Olmo, 1973). Harvest pruning, also known as cane severing, proved to be one of the most significant developments of this early DOV research, since it is the initial and most important step to initiating the drying process. While most of the world produces a lighter colored raisin, California growers produce 
raisins with natural dark coloring and with the bloom intact. Therefore, most efforts by California growers and researchers have been aimed at producing DOV raisins without the use of artificial drying aids (oleate sprays, etc.). While success was achieved with Black Corinth grapes (Christensen, et al, 1970), natural DOV production of Thompson Seedless worked with only limited success (Studer and Olmo, 1973).

The Australian industry has since developed several DOV raisin trellis systems which have helped them to reduce labor inputs and ensure successful production of oleate DOV raisins from the Sultana, Carina, and other cultivars. The Irymple system, which is described in detail by Gould and Whiting (1987), the Shaw systems as described by Shaw $(1986,1996)$, and the Swing-Arm system described by Clingeleffer and May (1981) are all examples. These trellis systems were developed to facilitate mechanical cane severing and harvest by separating the fruiting and renewal zones of the canopy. Similar efforts by California growers and grower organizations have led to more recent DOV developments (Malcolm, -1993). The goal of these efforts has been focused on the conversion of existing vineyards to DOV raisin production by installing trellis systems which employ south side fruiting/drying zones and north side renewal zones. Others serve to separate the renewal zone by training new shoots upward and allowing the fruit to develop on both sides of the trellis system. While all of these systems show promise in reducing harvest labor requirements, reducing rain risk, and even being able to dry Thompson Seedless grapes in most years, their production potential per unit of land may be limited due to the retention of traditional vineyard densities.

Development of the Simpson DOV Production System

\section{Capital Investment}

Capital investment in necessary resources began with the purchase of a 160 acre [65ha] parcel of land in 1991 for $\$ 3,500$ per acre $[\$ 8,650 / \mathbf{h a}]$. The actual planted acreage is 145 acres [59ha], with the rest of the land being used for building sites, roads, turning spaces, etc. The vineyard consists of own-rooted Fiesta grapevines planted in 1991 on a $5^{\prime} \times 8^{\prime}$ [1.5m x $2.4 \mathrm{~m}]$ (vine $x$ row) spacing $(1,089$ vines/acre $[2,691$ vines/ha]). (The Fiesta cultivar is described as having, medium to large clusters of berries with tender skin and good flavor (Weinberger and Loomis, 1974). Fiesta also ripens approximately 7-10 days earlier than Thompson Seedless, which is advantageous for on vine drying.)

The vines are head trained and cane pruned, with canes tied to a $6.5 \mathrm{ft}[2.0 \mathrm{~m}]$ high overhead trellis (Pergola) with a stake at each vine. To keep under-canopy humidity to a minimum, irrigation water is supplied via an automated subsurface drip irrigation (SDI) system with the capability of simultaneous fertilizer and gypsum injections as needed. Root intrusion into the emitters of the SDI tubing has successfully been prevented through periodic injections on small amounts of trifluralin. Weed control is also of little concern due to the shading created by the early season canopy development on the full overhead trellis. The initial investment required to establish the vines, irrigation system, and trellis system was $\$ 4,500$ per acre [\$11,120/ha]. Therefore, the total capital investment made for this vineyard was $\$ 8,000$ per acre $[\$ 19,770 / \mathrm{ha}]$. Updated estimates which include the use of studded steel stakes and grafted vines would bring this figure up to approximately $\$ 6,500$ per acre $[\$ 16,000 / \mathrm{ha}]$ plus the value of the land, which is currently selling in the $\$ 4,500$ per acre $[\$ 11,120 / \mathrm{ha}]$ price range.

Production Procedures

Separation of the fruiting and renewal canes is achieved by training each to opposite sides of 
the vine rows. By alternating the fruiting and renewal zones of adjacent vine rows, labor and machinery inputs can be optimized. Selection and training of renewal shoots, head cluster removal, and vine grooming, which entails suckering and leaf removal in the heads of the vines is an ongoing process performed by hand laborers throughout the growing season. Harvest cane severing is also performed by hand laborers in late July/early August. The DOV raisins are then mechanically retrieved approximately 6 weeks later. Following raisin retrieval, laborers clear the severed fruiting canes from the overhead trellis. At dormancy, hand laborers perform a minimal amount of finish pruning and cane tying prior to the start of the next season. The current season's renewal area becomes the next season's fruiting area and this process is repeated each growing season.

\section{Labor Requirements}

Actual labor hour requirements by operation and time of season for the Simpson DOV Production System are presented in Table 1. The net delivered weight for this vineyard in 1996 was 4.39 tons of raisins per acre at a weighted average moisture content of $13.2 \%$ (w/w). When adjusted to $16 \%$ moisture (w/w), the actual raisin yields in 1996 were 5.34 tons of raisins per acre $[12.0 \mathrm{mt} / \mathrm{ha}]$ in 1996 . The projected net delivered weight is expected to be 5.5 tons per acre [12.3 $\mathrm{mt} / \mathrm{ha}$ ] for the future. At the projected yield level, the labor hour requirement per ton of raisins will be approximately 31 hours $[34 \mathrm{hrs} / \mathrm{mt}]$. (As the vines mature and the cultural practice requirements are refined, this figure is expected to decrease over the next few years.) This is similar to the time requirements of traditional raisin production practices, but very different in the fact that labor hours are used much more intensively per unit of land while at the same time, being more evenly distributed throughout the year (see Table 2). This allows the grower to hire, train, and retain a smaller, more stable workforce which should also have more positive benefits for the local community than the seasonal influxes of migrant laborers. Vineyard management ląbor, which could be performed by the owner operator has not been included.

\section{Machinery Requirements}

Specialized equipment, including narrow, low-profile tractors and sprayers, as well as tractor-mounted harvesting equipment are crucial to the success of the Simpson DOV Production System. The critical equipment items used, (including new costs, hours of annual use, and operating costs) are presented in Table 3. Only the cash costs associated with equipment has been included in the production budget presented in Table 4 . These costs include labor, fuel, lubricants, repairs and maintenance, taxes, insurance, and housing. Hours of use for tractors are estimated at $10 \%$ higher than attached implements. Labor hours are estimated at $20 \%$ higher than that of the tractor in use due to set-up time, breaks, etc. Capital recovery of the additional, non-cash costs of the investment in machinery has not been included. These costs include interest and depreciation charges.

\section{Economics of DOV Production}

Actual costs by operation for the 1996 and 1997 seasons (including labor, materials, and machinery components) were used to prepare the cash operating budget presented in Table 4. Given the projected yield level of 5.5 tons per acre $[12.3 \mathrm{mt} / \mathrm{ha}]$ and an average price per ton of $\$ 1,025[\$ 1,130 / \mathrm{mt}]$, the gross revenue per acre would be $\$ 5,640$ [ $\$ 13,930 / \mathrm{ha}]$. By subtracting the total cash production costs presented in Table 4, we arrive at a net revenue per acre of $\$ 4,240[\$ 10,480 / \mathrm{ha}$ ]. These funds can be used for capital recovery of vineyard establishment costs, equipment costs, returns to management, and returns to the land. Traditional raisin growers experience gross revenues of approximately $\$ 2,050$ per acre $[\$ 5,060 / \mathrm{ha}]$ and net revenues of $\$ 600$ per acre $[\$ 1,500 / \mathrm{ha}]$ or less. 


\section{Risk Assessment}

It is important to note that rain risk is drastically reduced by the Simpson DOV Production System and terracers and paper trays are unnecessary. Normal rain events have not caused irreversible damage as is seen with traditional raisin production methods. Only severe storms would be of concern to growers using the Simpson DOV Production System. In the worst of drying seasons, DOV growers will likely be able to mechanically harvest partially dried fruit for artificial finish drying on the farm or at a commercial dehydrator. These costs will have to be absorbed as part of doing business or will need to be addressed by modified raisin reconditioning insurance offerings which are currently available. Although not recommended by the authors of this article, many growers using the Simpson DOV Production System may elect to not purchase raisin rain insurance at all.

\section{Conclusions}

This paper outlines the development of a commercially viable DOV raisin production system in the San Joaquin Valley of California. The Simpson DOV Production System has been used to establish a 145 acre Fiesta vineyard. Establishment costs, production costs, production practices, and yield data are presented. With appropriate management, use of the Simpson DOV Production System can increase raisin yield and net returns to growers.

*Bibliography

\section{3}

since 14 Aug 97 
Table 1-Actual labor hours required by cultural operation 1996/1997. Simpson Vineyards. Madera, CA

\begin{tabular}{|c|c|c|c|}
\hline Operation & Duration & $\begin{array}{l}\text { Labor Hours } \\
\text { (per acre) }\end{array}$ & $\begin{array}{l}\text { Labor Hours } \\
\text { (per hectare) }\end{array}$ \\
\hline Winter Pruning & Nov-Feb & 22.8 & 56.4 \\
\hline $\begin{array}{l}\text { Cane } \\
\text { Trimming/Ty ing }\end{array}$ & Nov-Feb & 16.7 & 34.0 \\
\hline Shoot Selection & Mar-Apr & 7.6 & 18.8 \\
\hline Shoot Training & Apr-Jun & 37.1 & 91.7 \\
\hline $\begin{array}{l}\text { Head Cluster } \\
\text { Removal }\end{array}$ & Apr-May & 25.0 & 61.7 \\
\hline \multicolumn{4}{|l|}{-cluster removal } \\
\hline \multicolumn{4}{|l|}{-suckering } \\
\hline - leaf removal & & & 1 \\
\hline Vine Grooming & Jun-Sep & 13.7 & 33.9 \\
\hline \begin{tabular}{|l} 
Irrigat ion \\
Maintenance \\
\end{tabular} & Mar-Oct & 3.5 & 8.6 \\
\hline Spray Program & Nov-Sep & 10.3 & 25.4 \\
\hline Harvest Pruning & Aug & 3.7 & 9.2 \\
\hline $\begin{array}{l}\text { Machine } \\
\text { Harvesting }\end{array}$ & Sep-Oct & 10.8 & 26.7 \\
\hline Clearing Canes & Oct-Jan & 7.1 & 17.5 \\
\hline \multirow[t]{2}{*}{$\begin{array}{l}\text { All Other } \\
\text { Pract ices }\end{array}$} & Jan-Dec & 11.4 & 28.1 \\
\hline & $\begin{array}{l}\text { Season } \\
\text { Total } \\
\end{array}$ & 169.6 & 419.1 \\
\hline \multicolumn{4}{|c|}{$\begin{array}{l}\text { Notes: } \\
\text { Most of the labor is performed by a permanent crew of } 5 \text { people, } \\
\text { not including the field supervisor. Addit ional laborers are } \\
\text { hired for the fol lowing practices. Winter Pruning, } 8 \text { people; } \\
\text { Shoot Selection, Training, Head Ciuster Removal, and Vine } \\
\text { Grooming, 15 people; Harvest Pruning, } 7 \text { people; and Machine } \\
\text { harvest, } 4 \text { people. Return to Labor Requirements }\end{array}$} \\
\hline
\end{tabular}




\section{Dried-on-the-Vine Raisins Becoming More Popular}

Following a frustrating 1998 raisin season, marked by labor shortages and weather woes UC Davis viticulture specialist Pete Christensen believes drying raisins "on-the-vine" anc harvesting mechanically will gain popularity. The key to the system's long-term success, says, is new varieties. In contrast to the traditional production system, where grapes are off the vine and laid on paper trays to dry in the sun, dried-on-the-vine (DOV) systems he workers simply clipping the stem that connects the grapes to the plant. The grapes dry tc raisins while still hanging in the canopy. On the vine, grapes take twice as long to dry, bc are not harmed by autumn rains, which cause mold and imbedded sand on raisins lying c the vineyard floor. But most importantly, the raisins and paper trays need not be laboriou collected. Rather a harvester drives amidst the vines automatically gathering the fruit in bins. Now in commercial production on only 3,000 acres of the San Joaquin Valley's 175,000 acres planted to raisins, Christensen's confidence in the system's potential drive studies at the UC Kearney Ag Center on four trellis systems and a number of varieties. "dominance of late-maturing Thompson seedless grapes in the Valley is a challenge to DI development," Christensen said. Earlier maturing Zante Current, Fiesta and DOVine grap show more promise for DOV production. For more information contact Christensen at (5E 646-6552, christen@uckac.edu. Tip by Jeannette Warnert, (559)225-5611, iwarnert@uckac.edu.

Back to News Home Page 


\title{
THE RAISIN GRAPE INDUSTRY
}

\author{
Paper Presented at the Immigration and Changing \\ Face of Rural California Conference \\ University of California Kearney Research Station \\ September 10-12, 1998 \\ Bert Mason, Ph.D. \\ Professor, Department of Agricultural Economics \\ Director, Center for Agricultural Business \\ California State University, Fresno
}

\section{Introduction}

The raisin grape industry is centered in the San JoaquinValley of California, with virtually all U.S. production located within a sixty-mile radius of Fresno. Over 5,000 growers farm about 125,000 to 150,000 acres of raisin grapes, which produce about 350,000 tons (dry basis) of raisins per year.

Since its inception in , the raisin grape industry has relied on immigrant labor to harvest the crop. The harvest window is short (3-4 weeks), tense due to the ever-present threat of rains, and requires a large, temporary workforce of perhaps 40,000-50,000 individuals. This workforce is entirely foreign-born and increasingly illegal; some estimates place the proportion of the harvest work force that is fraudulently documented in the range of $60-70 \%$.

The raisin grape harvest is considered to be a bellwhether for the rest of California agriculture. With its heavy reliance on a temporary, migrant and largely illegal workforce, it is hypothesized that any restrictions on labor supplies would be noticed most immediately and visibly in this industry. While the crop has been successfully harvested in the past few years, growers are uncomfortable with the current situation. Labor supplies have been reduced by increased interdiction by the Border Patrol, but there has been very little interior enforcement by the INS. The nervousness caused by the threat of greater enforcement has resulted in a major push by the raisin industry for a temporary guest worker program.

\section{Industry Overview}

Grape vines are a permanent crop. While a newly-established vineyard will reach commercial 
pivuuciuon alteı ıvu years, it generally takes six or seven years to reach full production.

Purchasing suitable land and establishing a vineyard for raisin production typically requires an investment of over $\$ 10,000$ per acre.

There are between 5,000 and 6,000 raisin growers; the average grower has about 50 acres of raisin grapes and is usually family-owned and operated (Alvarado, Mason and Riley, 1993; U.S. Department of Commerce). In a survey of 325 raisin growers in 1991, we found that almost $40 \%$ of the respondents also grew crops other than raisin grapes, but raisin grapes were the primary crop for $80 \%$ of the growers surveyed. The majority of the raisin growers seem to depend on offfarm jobs for additional income.

There are several grape varieties used for raisins, including Muscat, Sultana, Zante currant, and Thompson seedless. About 95 percent of California raisins are made from Thompson seedless grapes, with about 270,000 acres of this variety planted in the state. It is difficult to determine the exact acreage devoted to raisins each year, since Thompson seedless grapes also have table, wine and juice uses.

California's production of raisins has grown fairly steadily since the 1920 's, when annual production was about 135,000 tons. Total production in recent years has ranged between 325,000 and 380,000 tons, with growers' returns typically averaging about $\$ 350$ million annually.

Raisins are sold to one of twenty packers, including two cooperatives and 18 privately-owned operations. One cooperative, Sun-Maid, controls about $40 \%$ of the annual crop.

The marketing of raisins is controlled through a Federal Market Order, which regulates the supply of raisins to be put on the market each year. The Federal Raisin Market Order, established in 1949, is administered by the Raisin Advisory Committee (RAC). The most important function of the RAC is to determine how much of the crop will be marketed immediately as "free tonnage" and how much will be placed in the "reserve pool" that will be marketed to noncompetitive outlets such as subsidized exports or the school lunch program. The actual price received by the grower is the weighted average of the free and reserve prices.

In recent years, approximately one-third of the crop has been exported despite competition from low-cost producers such as Turkey, Greece and South Africa. The University of California Cooperative Extension Service estimates that cash costs to produce a ton of raisins is about $\$ 840$. In many years, the average price received by growers is less than this level. The average price received by growers for the 1997 crop year is estimated to be $\$ 895 /$ ton, which is close to breakeven level for cash costs (Bedwell, 1998). Competition in world markets and low economic returns helps mold the industry's views on labor costs.

\section{Employment}

There are no accurate data on total employment in the raisin industry. EDD estimates (which have not been published since 1996) combine all grape industry employment intoone category, and farm labor contractors are reported as a separate category with no identification of crops in which they work. The industry claims that 50,000 to 60,000 individuals are required to harvest the crop in a timely manner. Whatever the total requirements, it is safe to say that the industry requires a large, temporary workforce for a short harvest season.

Labor relations in the industry are casual, with farm labor contractors acting as intermediaries between the growers and workers. In our 1991 study, we found that the use of farm labor contractors among the employer respondents rose from $35 \%$ in 1985 to $60 \%$ by 1991 . Given the concern about tight labor supplies in recent years, it is likely that more than $70 \%$ of the growers 
are now using farm labor contractors to obtain harvest workers.

Production of raisin grapes is very labor-intensive, with nearly every task requiring hand labor. It is estimated that about 80 to 85 hours of seasonal work per acre are required each year to produce raisins (Mamer and Wilkie), most for pruning and harvesting. Starting in December or January when the vines are dormant, the previous season's vine growth is pruned by hand, and the next season's vines are tied to wire trellises. From spring through harvest, the normal cultural practices of irrigating and control of weeds and pests are completed.

By mid- to late August, the grapes usually have sufficient sugar to be picked. The grapes are cut from the vine with a short, curved knife, and placed in a pan by the picker. The picker then places the grapes on a paper "tray" (a name that lingers from the time when grapes were dried on wooden trays) that is usually 24 " by $36 "$ (Peacock and Christensen). Each paper tray contains 18 22 pounds of green grapes, which are allowed to dry naturally in the sun. After about one week, workers turn the ??grapes on the trays??? trays so that the drying process is uniform. In about two weeks total time, the grape trays are manually rolled up and left for another week or so to finish the drying process. It is during this three-week drying period that the crop is vulnerable to rain damage; heavy rain can cause a complete crop loss. This is a major factor in exacerbating the peak demand for labor. If inclement weather threatens, every grower is seeking harvest workers.

All of the major tasks (pruning, vine-tying, picking and rolling trays) are paid on a piece-rate basis. There is no consistent data series on piece rates or earnings in the raisin industry. In 1991, we found the prevailing piece rate for picking raisin grapes was 16 cents per tray, and that this rate had been fairly constant since 1986 (Alvarado, Mason and Riley, 1992). The Employment Development Department conducted a prevailing wage survey during the 1994 harvest, and found the prevailing rate to be 17 cents per tray (EDD, 1994). Recent interviews with EDD personnel indicated that the prevailing piece rate during the 1997 harvest was $18-19$ cents per tray, although the local press reported rates as high as 21-23 cents per tray.

Worker productivity varies due to individual experience and ability as well as crop yields. The general rule in the industry is that a good worker can pick about 350 trays per day. With an average work day of about nine hours, hourly earnings for raisin pickers are generally in the range of $\$ 6.50$ to $\$ 7.50$ per hour.

As part of our study of the raisin industry in 1991, we interviewed 125 workers employed in the raisin harvest. We found that virtually no workers were provided any type of fringe benefit beyond the required unemployment insurance and workers' compensation, and a suprisingly high percentage of workers weren't even aware that these were provided by employers. Approximately 17 percent of the workers we interviewed indicated that they lived in employer-provided housing, and only 7 percent of the employers surveyed in 1991 responded that they provided transportation for their harvest crews. Two-thirds of all workers interviewed indicated that they had to pay for a ride to work from another worker, a foreman, or a raitero. The median cost per day for these rides was four dollars.

\section{Harvest Workforce Demographics}

One-hundred and twenty-five workers employed in the 1991 raisin harvest were interviewed at different farm sites in Fresno County (Alvarado, Mason and Riley, 1992 and Alvarado, Mason, Riley and Hagen, 1993). The workforce was entirely Hispanic, with 94 percent born in Mexico. Only one worker was born in the U.S., with the remainder from Central America. Of the Mexican-born workers, the majority were from the traditional sending areas of Michoacan and Guanajuato There are indications that there are increasing numbers of migrants from newer sending areas in Mexico such as Oaxaca and Zacatecas, but our sample did not capture these 


\section{workers.}

Ninety-two percent of the workers were male, and 41 percent were single. Most of the married males were in the U.S. without their families. The median age of the workers was 28 , and the median year that the workers first came to the U.S. was 1983. It is likely that the median age of the workforce in 1998 is similar to what we found in 1991, but their first sojourn to the U.S. was likely to have occurred in the past five years.

The formal level of schooling among this workforce is low. The average worker had completed only five years of school in Mexico, and only seven of those interviewed had any formal education in the U.S. Literacy rates are also low. Spanish is regularly spoken by 99 percent of the workers, and less than 6 percent indicated that they spoke English "fairly well" or "very well". Eighty-seven percent said that they understood English "very little" or "not at all".

Slightly over 35 percent of the workers we interviewed responded that they were working in the U.S. with fraudulent documents or with no documents whatsoever. We did not verify this response in any manner, so it probably represents the lower boundary of the illegal component of the harvest workforce. Other analyses suggest that the proportion of illegal workers in agriculture has been increasing by 3-5 percent per year. If this estimate holds true for the raisin industry, the current proportion of the workforce that is illegal is in the range of 60 to 70 percent.

\section{Interest in Mechanization Grows}

When we conducted our studies in the early 1990's, there was relatively little interest in the industry in exploring mechanical alternatives for the raisin harvest. Since that time, it appears that concern over future labor supplies due to increased enforcement activities is changing attitudes in the interest. Of course, the first choice for representatives of the raisin industry (as well as those who represent other labor-intensive sectors of California agriculture) is to press for continued immigration via some form of a temporary guest worker program. It does appear, however, that several recent developments hold promise for mechanizing much of the heavy-hand tasks involved in growing raisin grapes.

An additional concern for growers using the traditional dried-on-the-ground production method is the vulnerability of the raisins to rain damage. An entire crop can be destroyed if signficant rain falls during the crucial two- to three-week drying period.

Much of the early research on mechanical harvesting methods for raisin grape production was conducted in Australia (Simpson, et al.). In California, Earl Rocca from Biola developed a machine to harvest raisin grapes in the early 1970's. Rocca's approach uses a harvest machine adapted from a wine grape harvester. Rocca severs the canes and allows the berries to partially dry. The machine then picks the grapes and places them on a continuous paper tray. Rocca estimates that he saves about \$300/acre compared to hand-picking. (Watrous, 1997).

Recent research and commercial efforts to develop mechanical harvesting systems have focused on various dried-on-the-vine (DOV) approaches. Generally, DOV systems involve leaving the grapes on the vines, cutting the canes, and allowing the grapes to dry while still on the severed canes. Once the drying process is complete, the raisins can be harvested with a variety of machines.

Sun-Maid Growers, Inc. of California has developed and patented a DOV raisin production system that is primarily aimed at retrofitting existing vineyards. This system uses a speciallydesigned trellis which allows the separation of the vine canopy into fruiting and renewal zones. The fruiting zone, which later becomes the drying zone, is oriented toward the south side in easthttp://migration.ucdavis.edu/rmn/Mason-Raisin.html 
west directional rows. This orientation is designed to enhance the drying rate. Several companies are also involved in designing necessary equipment such as cane severing units, leaf blowers/removers, and harvesters.

Detailed economic analysis of the Sun-Maid DOV system is not available. Costs for conversion can range from $\$ 1200$ to $\$ 2000$ per acre. One grower estimates that he saves about $\$ 150$ to $\$ 200$ per acre in labor costs (Warner, 1998). This suggests a fairly long payback period for the investment, and widespread retrofitting is not likely unless labor supplies become far more scarce than in recent years.

One grower in the Madera area, Lee Simpson of Simpson Vineyards, Inc., has completely redesigned his vineyard system to incorporate all aspects of production such as cultivar selection, trellis systems, planting density, irrigation, and mechanization. In 1992, 160 acres of Fiesta vines were planted in a high-density manner (1,089 vines per acre, about twice the normal planting density). An overhead trellis system is used and the vines are head trained and cane pruned. Fruiting and renewal zones are placed in alternating row middles from year to year. Canes are severed by hand during late July or early August and the raisins are allowed to dry on the vine. Drying takes approximately six weeks, but rain during the drying period does not damage the raisins. Tractor-mounted harvesters are used to knock the raisins off into bins (Mason, Striegler and Berg, 1997).

For the 1997 crop year, the Simpson vineyard yielded 5.34 tons/acre of dried raisins (Simpson, et al., 1997). Vineyards using traditional planting and drying techniques usually average about 2 tons/acre; the economic advantage of the Simpson system depends entirely on this yield differential.

The initial investment in the Simpson vineyard to establish the vines, irrigation system and trellis system was $\$ 4,500$ in 1991 (ibid.). Land costs were another $\$ 3,500 /$ acre, for a total investment of $\$ 8,000$ per acre. Updated cost estimates for 1997 bring the investment cost up to $\$ 6,500$ /acre plus $\$ 4,500 /$ acre for land, or a total capital cost of $\$ 11,000 /$ acre. According to local farm land appraisers, recent sales of good Thompson seedless vineyards in the area have been recorded in the $\$ 8,000-12,000 /$ acre range.

Simpson, et al. estimate that gross revenues for vineyard are $\$ 5,640$, with cash costs estimated to be $\$ 1,262$ /acre. This leave a net cash revenue of about $\$ 4,240 /$ acre using the Simpson system. Growers employing traditional production systems can generally expect a net cash revenue of about $\$ 600 /$ acre.

The Simpson system requires a substantial about of hand labor to perform tasks such as vine training and severing throughout the year. The total labor required per ton of raisins is projected to be about 31 hours/ton, which is only slightly less than that required for traditional systems (approximately 40 hours/ton). The advantage in terms of labor management is that a small crew can be employed throughout the year, with only minimal supplemental labor required during cane pruning in harvest. Simpson employs a permanent crew of five workers. Additional laborers are hired for the following practics: winter pruning, 8 people; shoot selection, training, head cluster removal and vine grooming, 15 people; harvest pruning, 7 people; and machine harvest, 4 people. (Ibid.) A vineyard this size using conventional dried-on-the-ground methods would probably seek a crew of 40-60 pickers for a few days in September, and would also hired a large peak crew in December-January for pruning. Thus, the DOV approach holds the potential of providing more stable and less seasonal employment while requiring far fewer temporary (and likely immigrant) workers.

\section{Conclusions}


Central California's raisin grape industry is highly-seasonal and labor-intensive. Although precise enumerations are not available, industry sources estimate that 40,000-50,000 workers are used each year for the harvest period of three to four weeks. The raisin grape harvest is also characterized by increasing dominance of farm labor contractors and a workforce that is certainly more than 50 percent fraudulently documented.

In recent years, raisin growers and their representatives have voiced concern that Border Patrol activities have reduced immigration and have caused labor shortages. There are, however, no documented incidents of crops not harvested due to inadequate picking crews. Moreover, harvest piece rates have gone up only modestly in the past decade and have not kept pace with increases in the minium wage in the past two years. These modest piece rate increases do not suggest labor "shortages."

Until recently, there was very little interest among raisin growers in pursuing mechanized alternatives to hand-harvest. In 1991, only 28 percent of raisin growers who responded to a survey indicated that they would consider shifting to a mechanized harvest system in the event of a labor shortage (Alvarado, Mason and Riley, 1992). Newly-developed technologies have been introduced since that time, and it appears that industry attitudes towards mechanization are changing.

Dried-on-the-vine production systems hold promise for reducing harvest labor requirements. For new vineyards, DOV appears to be technically sound and economically advantageous compared to conventional production systems. Retrofitting existing vineyards does not have the advantage of increased production and therefore is not as attractive for the grower.

At this stage, only early adopters are experimenting with DOV production systems. Several barriers to widespread conversion to DOV exist. First, retrofitting of existing vineyards has a fairly low return on investment and it may be difficult to secure the $\$ 1200$-2000/acre of financing necessary to make the capital investment. Second, the average raisin farm is only about 50 acres; a major investment to convert to DOV may be out of reach for most of these growers. Third, the average age of a raisin grower is 63 years. This is not a group that is likely to take on great risk. Fourth, raisin growing is currently characterized by over-production and relatively low returns. For the 1997 crop year, only $59 \%$ of the crop was sold as free tonnage. Preliminary analyses predict that there will be even greater over-production of raisins in 1998 due primarily to reduced demand for Thompson seedless grapes by wine and juice processors.

The final barrier to widespread adoption of DOV or other mechanized systems is the continued availability of immigrant labor. Border interdiction has likely reduced the supply of harvest labor, but there has been virtually no interior or employer enforcement activity by the INS. If this becomes an enforcement priority and immigrant labor flows are effectively reduced, interest in mechanical alternatives will increase dramatically. 
Appendix 8

Production practices and sample costs for growing organic grapes 


\section{UNIVERSITY OF CALIFORNIA COOPERATIVE EXTENSION PRODUCTION PRACTICES AND SAMPLE COSTS FOR ORGANIC RAISIN GRAPES SOUTHERN SAN JOAQUIN VALLEY 1997}

- OVERVIEW OF ORGANIC RAISIN GRAPE PRODUCTION

- COST AND RETURNS STUDY FOR ORGANIC RAISIN GRAPES

\section{Prepared by:}

Karen Klonsky, Extension Economist, Department of Agricultural and Resource Economics, U.C. Davis

Laura Tourte, Postgraduate Researcher, Department of Agricultural and Resource Economics, U.C. Davis

\section{Contributing Authors:}

Pete Christensen, U.C. Cooperative Extension Specialist, Kearney Agricultural Center Michael Costello, U.C. Cooperative Extension Farm Advisor, Fresno County Chuck Ingels, U.C. Cooperative Extension Farm Advisor, Sacramento County George Leavitt, U.C. Cooperative Extension Farm Advisor, Madera County Pete Livingston, Staff Research Associate, Department of Agricultural and Resource Economics, U.C. Davis

Cooperators:

Tim \& George Bitter, George H. Bitter Farm, Madera County Harjinder Singh Gill, Nuvjug Farms, Kern County Mike McCutcheon, McCutcheon Enterprises, Inc., Fresno County Hunter Nadler, Nadler Ranch, Madera County Chris Steggall, National Raisin Company, Fresno County

\section{UNIVERSITY OF CALIFORNIA COOPERATIVE EXTENSION OVERVIEW OF ORGANIC RAISIN GRAPE PRODUCTION SOUTHERN SAN JOAQUIN VALLEY - 1997}

\section{Introduction}

The California grape industry ranks first in grape production in the nation with roughly 650,000 bearing acres. This produces about $90 \%$ of the total United States grape crop. From 1992 to 1995, grapes were the second largest contributor to farm income in California, with a gross value of between $\$ 1.7$ and $\$ 1.8$ billion for juice, raisin, table and wine grapes combined. Raisin grape production is concentrated in the Southern San Joaquin Valley, with the largest acreages located in Fresno and Madera counties.

By comparison, organic agriculture represented approximately $0.5 \%$ of the total farmed acres and total gross sales for all agriculture in California during the 1992-1993 time period, excluding 
dairy and livestock. Fruit and nut crops represented $42 \%$ of the total farmed acres and $44 \%$ of total gross sales for organic agriculture. Industry experts consider organic grapes to be a leading organic commodity in the state. Like production for all raisin grapes, the majority of organic raisin grapes are produced in the Southern San Joaquin Valley.

This overview is meant to familiarize the reader with grower practices and important issues facing producers of organic raisin grapes today. The first section details the seasonal flow of operations for organic raisin grape production. The subsequent sections discuss cover crops and floor management, as well as pest management. Following these discussions, grower risk and marketing are addressed. The current status of regulations governing organic commodities is encapsulated in the final section.

\section{Production Practices}

Many of the production practices for organically grown raisin grapes are similar to those of a conventionally grown crop. Cultural operations typically begin in the fall by re-leveling the vineyard row centers (middles), irrigating vines postharvest and planting a cover crop. Pruning, tying and vineyard maintenance take place between December and March depending on vineyard conditions. Most of the fertilization, irrigation, cultivation, pest management and related operations are performed in the spring and summer months. Harvest takes places in August and/or September.

\section{Ground Work}

Production practices begin after harvest by re-leveling vineyard middles. Depending on soil type and tilth, some growers then work the ground with a subsoiler (ripper) in every middle or in alternate middles. For example, growers in areas with heavy, compacted soils may subsoil every middle, while growers with less problematic soils may subsoil every other middle. Subsoiling is intended to improve water penetration and encourage root growth. However, not all vineyards are subsoiled each year. The vineyard is then disced and furrowed; a postharvest irrigation follows. The postharvest irrigation provides water for the grapevines, and in addition, adds moisture to the soil profile for planting a cover crop. Growers then drill or broadcast and till cover crop seed in vineyard middles. (Refer to the Cover Crops/Floor Management section for more detailed information.)

Soil amendments are applied to vineyard soils when plant tissue, water and soil analyses, as well as grower experience, have shown it to be appropriate. When nutrient deficiencies are detected, organic raisin grape growers amend soils with compost, livestock manure, gypsum and/or fish and kelp products. If compost or manure is used, it is often spread throughout the vineyard to supply nutrients to the vines, add organic matter to the soil and stimulate microbial activity. Alternatively, compost or manure may be spread in only vineyard middles or rows depending on the vineyard's particular needs. Gypsum is used to add calcium to the soil, improve soil tilth for soils high in sodium and/or improve water penetration with low salt irrigation water. Fish and kelp products add very small amounts of nitrogen, phosphorus, potassium, micronutrients and other organic constituents to the soil. They may also be foliar-applied. When used, these materials are applied either in the fall or spring months. Whether or not applications take place on a yearly basis depends on the soil conditions in each vineyard.

\section{Pruning and Vineyard Maintenance}

Vineyards are usually pruned between December and March each year. Larger prunings (arms and trunks) are removed from the vineyard. Smaller prunings are thrown into the center of every other row where they are shredded and chopped with a brush shredder, thus returning organic matter to the soil. Shredding and chopping is performed soon after pruning or later in the season in conjunction with cover crop mowing depending on the amount of rainfall, vineyard floor 
management practices and frost conditions.

Vineyard maintenance consists of multiple practices, including replanting missing vines, replacing stakes and end posts, tying canes, and trellis and wire repair. Vineyard maintenance takes place after pruning operations.

\section{Pest Management}

Pest management techniques for the control of diseases, insects, mites, weeds and vertebrates begin shortly after bud break and continue throughout the spring and summer months. Pest pressure varies depending on farm location, seasonal conditions and the previous year's pest incidence. (Refer to the Pest Management section for further information.)

Irrigation. Vineyard irrigations (other than the postharvest irrigation) are usually performed from late March through early August. In this area, furrow irrigation is the most common method of application. District (surface) and pumped (well) water are both used to irrigate the crop. The amount of each type of water that is used depends primarily on district water availability. Growers either irrigate every middle or every other middle to allow for flexibility in scheduling operations, especially when a cover crop is planted.

Total water use for each vineyard varies from location to location and depends on soil type and structure, the amount of rainfall and residual soil moisture, rooting depth of the vines, water availability and floor management practices. Cover crops and soil organic matter content may also play a role in the total amount of water applied and the number of irrigations each year. Cover cropped soils, or soils amended with organic matter have been shown to improve water penetration and infiltration rates. Therefore, irrigation efficiency may be increased by reducing surface ponding and/or runoff.

Frost protection is mostly achieved through floor management and irrigation practices in the Southern San Joaquin Valley. Therefore, growers do not have on-farm investments specifically for frost protection. In periods of frost danger, growers flood irrigate to moisten the soil and decrease the risk of frost damage.

Vineyard irrigations end at least two to three weeks prior to harvest to minimize vegetative growth, enhance crop maturity and quality, and ensure that soil is dry enough for laying down raisins. To prepare the vineyard for harvest, terraces are formed in the vineyard middles with a specialized terrace implement. Sufficient moisture must remain in the soil, however, to sustain the vines through the harvest and raisin drying process.

\section{Harvest}

Grapes are harvested by hand in August and/or September. Clusters are set on paper trays, which are laid on terraces to dry, after which time they are turned and rolled before removing from the field. Turning is performed primarily to expose the bottom fruit for evenness and acceleration of drying, and for this reason may be omitted from harvest practices in ideal drying weather. After drying, fruit is boxed (in bins) in the field and transported on trailers to a shaker for removal of sand and leaves. If the crop is relatively free of sand and leaves, shaking is also omitted from harvest practices, provided it is not required by the packer.

After these operations, fruit is transported to a packer for inspection by a United States Department of Agriculture (USDA) representative for crop maturity, quality and moisture. After inspection, the packer retains control of the product for marketing purposes. (For additional information on marketing, refer to the Grower Risk and Marketing section.)

Yields of organically and conventionally produced raisin grapes are similar, and range from 
approximately 1.5 to 3.0 tons per acre using a drying ratio of 4.1 to $4.5: 1$ (green fruit to raisin grapes). Yields vary depending on a number of factors including the vineyard planting density, vineyard age, production location and yearly growing conditions. The vast majority of raisins are produced from the Thompson Seedless grape variety.

\section{Cover Crops and Floor Management}

\section{Potential Benefits}

Cover crops have numerous potential benefits. Water penetration and infiltration can be improved by root growth of a cover crop and by returning organic matter to soils. Grasses are particularly helpful in improving soil structure and increasing microbial activity, which has been shown to promote aggregate stability. This is important because soil erosion and degradation processes are reduced in aggregated soils. In addition, nutrients are released as microbes decompose organic matter. Leguminous cover crops can add nitrogen to the soil through nitrogen fixation processes. Weed suppression may be another benefit. Cover crops increase plant diversity in a vineyard and in the flowering stage can provide pollen and nectar to attract and sustain beneficial arthropods (insects and predatory mites). They can also reduce dust problems, which in turn can help reduce spider mite pests. Lastly, farm machinery may be able to enter vineyards earlier in the season in situations where a cover crop's mat of root and vegetative growth provides support on wet soil. This may also serve to reduce soil compaction.

\section{Potential Disadvantages}

There are also potential disadvantages with cover crop use. Cover crops can attract arthropod and/or rodent pests to the vineyard. Cover crops increase the cash costs associated with planting and may require the rental or purchase of specialized farm equipment. Competition between vines and cover crops for water and nutrients may increase the need for additional inputs. In this region, water use in particular should be taken into consideration because it may be in short supply in some years and for some farms. However, some growers view the cost of planting and maintaining a cover crop as the cost of producing nitrogen and/or improving soil quality for the long-term. The presence of a cover crop after bud break may increase the hazard of frost. This is due to the insulative effects that reduce radiant heat absorption during the day and its release at night from the soil. Frost hazard can be minimized by mowing the cover crop close, early incorporation, or cover cropping in alternate middles only.

\section{Cover Crop Selection}

Cover crop species and mixes should be selected for compatibility to a particular vineyard's operations, and should also be utilized to maximize potential benefits. In this region, annually sown leguminous cover crops are planted, often as mixes. Species include bell beans, clovers, medics, field peas and vetch ('Cahaba white', common, hairy, 'Lana' woollypod and purple). They are usually planted to add nitrogen and organic matter to the soil, and to provide a habitat to attract and sustain beneficial arthropods. Also, 'Cahaba white' vetch functions as a relative nonhost to most nematode species in the area. Cereal grasses (barley, oats and rye) are planted to increase cover crop biomass and return organic matter to the soil. Grasses, especially cereal rye ('Merced'), can be planted later in the fall to establish a good stand than legumes, thereby providing growers with some planting flexibility in years when harvest operations and ground work are delayed. In this area, a mixture of legumes and grasses is often planted to derive some of the benefits associated with each species. Cover crop selection is generally tailored to meet the unique needs of each vineyard and is often determined by observation and experimentation over a period of years.

\section{Planting}

Cover crops are commonly planted in six-foot strips in vineyard middles by either drilling or broadcasting and tilling seed. If nitrogen is not a limiting factor, cover crops may be planted in 
every other middle rather than every middle. Good stands are more likely to be established when a seedbed is well-prepared, that is, when the vineyard is re-leveled after harvest, disced to incorporate weeds and residue (trash) from the harvest, and irrigated either before or after planting. The postharvest irrigation mentioned above often functions as a preirrigation for planting a cover crop. Therefore, growers do not always irrigate the vineyard after the cover crop is planted, but instead depend on fall and winter rains for subsequent cover crop growth. However, fall and early winter rainfall is often insufficient for early cover crop growth in this area. Therefore, stand establishment may be improved by irrigating after planting.

\section{Floor Management}

In the spring months, floor management practices vary depending upon grower preference, equipment complement and yearly production conditions. Growers incorporate the cover crop either by mowing and discing, or by discing only. Cover crop incorporation speeds decomposition of the vegetation and recycling of nutrients for crop production. It also serves to reduce competition between the vines and the cover crop for water and nutrients. In contrast, some growers mow the cover crop in late winter or early spring to reduce only a portion of the above ground biomass, then allow the cover crop to regrow, and possibly reseed, until early summer when it is incorporated by both mowing and discing. Under these conditions, the cover crop is utilized to attract and sustain beneficial arthropods, reduce dust (therefore spider mite pests) later in the growing season, increase water penetration and provide reseeding capability. The cover crop's nitrogen contribution is considered less important. However, this practice may lead to substantial water use by the cover crop.

After a cover crop is incorporated, most growers disc periodically in vineyard middles during the remaining spring and/or summer months to control weeds, typically after irrigating the vineyard. Weeds in vine rows are controlled by mechanically cultivating with an in-row cultivator (e.g. a French Plow, Clemens or comparable implement), and by hand hoeing. Therefore, little or no additional water is usually required for cover crop growth or for resident weeds during the remainder of the growing season. The number of discings and hand weedings depends on weed species and density and will therefore vary from location to location.

\section{Pest Management}

Pest identification, monitoring and prevention are essential elements of successful raisin grape production. This is especially true for organic production because many of the pesticides that are currently used by producers of conventionally grown raisin grapes are not approved for use by organic raisin grape growers. Sulfur is a notable exception. Many of the legal (allowed) pest control products may be less effective for acute problems than the synthetically formulated pesticides prohibited in organic production. For raisin grapes, growers either monitor their own vineyards or enlist the services of an agricultural professional, who functions jointly as a licensed pest control advisor (PCA) and an input supplier.

Treatments such as natural pesticides and biological controls are used to decrease pest damage and reduce short-run economic risks when needed. Growers should be certain that any materials used are in compliance with the rules and regulations of federal, state and organic certification agencies. (Refer to the Regulation of Organically Grown Commodities section for further information.)

\section{Diseases}

Diseases that occur in Southern San Joaquin Valley organic vineyards include: powdery mildew (Uncinula necalor), phomopsis cane and leaf spot (Phomopsis vilicola), bunch rot (Botrytis cinerea) and various other rots and molds associated with grape harvest and fruit drying. Disease incidence is often increased by moist, humid weather and spring and summer rains. Powdery 
mmuew muecuons are reauced witn sultur applicatıons. Sultur applications, which typically begin at bud break, are applied as a dust or in wettable form seven to 12 times per year depending on seasonal conditions. The incidence of phomopsis cane and leaf spot is reduced by wettable sulfur and copper sprays, which are applied immediately preceding rains. The same sulfur applications used for phomopsis control may also assist in powdery mildew control. Bunch rot infections in grapes can be reduced by canopy management. For example, leaves may be removed around clusters to open the canopy to sunlight and increase air circulation. However, leaf removal to control bunch rot in raisin grapes is not a common practice in this area, nor is it practical with cane-pruned vines. Other measures, such as powdery mildew and caterpillar control, are utilized. This is because the damage caused by both caterpillars and powdery mildew can lead to bunch rot.

In addition, some growers treat grapevines with the plant growth regulator gibberellic acid during bloom. Gibberellic acid assists in bloom thinning, and its use may help lessen the incidence of bunch rot. However, some certification agencies restrict or prohibit its use. Growers should therefore be certain that this material is acceptable for use in organic production by appropriate private certification agency standards.

Crop losses that occur from the various other molds and rots can be reduced when care is taken to avoid fruit injury during both the growing season and harvest. Also, losses can be reduced during fruit drying if vineyard terraces are formed with an adequate slope and appropriate firmness. This serves to minimize moisture retention and accelerate drying if rains should occur before fruit is removed from the field.

\section{Insects}

Growers indicate that crop damage from insects is not significant in long-standing organic raisin grape vineyards in this region. For one reason, naturally occurring beneficial arthropods (e.g., parasites and predators) are often present in vineyards in large enough numbers to assist in pest reduction. Beneficial arthropods include: spiders, predatory mites, green lacewings (Chrysopa spp.) and other generalist predators. Nevertheless, fluctuations in both pest and beneficial arthropod populations occur. Therefore, growers sometimes release predators and parasites to augment levels that already exist in the field. This helps regulate pest densities on a year-to-year basis, and may assist in controlling pests in areas of the vineyard where significant pest outbreaks occur

Growers report that five arthropod pests have periodically infested vineyards in the area and been responsible for some damage in years when conditions were optimal for insect development. The arthropod pests are: omnivorous leafroller (Platynota stultana), grape leafhopper (Erythroneura elegantula), variegated grape leafhopper (E. variabilis), western grapeleaf skeletonizer (Harrisina brillians), and spider mites. Life cycles and feeding habits for each pest vary, however, the leaves and the fruit are most often damaged by these arthropods.

The mineral insecticide cryolite and the bacteria Bacillus thuringiensis $(\mathrm{Bt})$ are commonly used for omnivorous leafroller control. In addition, a relatively new $\mathrm{Bt}$ and sulfur formulation is used to control this pest. When necessary, insecticidal soap is used to reduce populations of leafhoppers. Also, some growers trap leafhoppers before they enter the field by attaching a 6-inch yellow sticky tape to end posts on two sides of the vineyard's perimeter. Although not recently considered a major raisin grape pest in this area, western grapeleaf skeletonizer is controlled, if necessary, with cryolite and Bt.

Spider mite control is achieved through a variety of techniques. Irrigation water should be managed to avoid vine stress, which may exacerbate spider mite problems. As mentioned above, cover crops help to reduce dust in vineyards, which otherwise contributes to increased spider mite 
populations. Summer cover crops may therefore be helpful in managing spider mites, particularly in areas with sandy soils and a history of significant pest infestations. A number of growers also release predatory mites to assist in spider mite control. The application rate for each input and the number of acres treated will depend on vineyard location and the extensiveness of a particular infestation.

\section{Weeds}

Weeds in the vineyard middles are most often controlled by discing. Within vine rows, growers use specialized equipment such as a Bezzerides cultivator or an in-row cultivator. Some growers also hand weed in addition to mechanical cultivations to control weeds in vine rows. Perennial weeds are usually more difficult to control than are annual weeds. For this reason, vineyards with higher densities of perennial weeds often require greater control measures to be taken.

\section{Vertebrate Pests}

Only minor crop damage from birds and ground squirrels occur in organic vineyards in this area. Therefore, vertebrate pest damage is not deemed significant enough to require specific control measures on a regular basis.

\section{Grower Risk and Marketing}

\section{Risk}

Growers perceive that the risks associated with general farm management, and in particular pest management, are increased somewhat for organic raisin grape production relative to conventional production. This is especially true for the transition years, or the years when agricultural production changes from conventional to organic practices. The production techniques commonly used in conventional systems are sometimes inappropriate for organic systems, necessitating adoption of new methods of production. Growers therefore find that the "learning curve" for organic production and farm management is steeper during the transition period. Some organic growers also report a willingness to bear somewhat higher costs for organic production relative to conventional production. These higher costs are not viewed as short-term monetary losses, but rather as long-term investments in such areas as soil fertility and environmental quality.

Federal crop insurance is purchased by almost all growers, both organic and conventional, to reduce the production risks associated with specific natural hazards. Insurance policies vary and range from a basic catastrophic loss policy to one that insures losses for up to $75 \%$ of a crop. In addition, some growers also purchase reconditioning insurance, which covers some of the costs for reconditioning raisins (e.g. turning, rolling, washing and drying) if rains should occur during the harvest period. Insurance costs will vary depending on the type and level of coverage.

\section{Marketing}

The raisin grape market is regulated by a federal marketing order that is administered by the Raisin Administrative Committee (RAC). Each year, the RAC sets minimum industry standards that must be met by both the organic and conventional crop. In addition, the RAC regulates, on a percentage basis, the amount of the harvested crop that is offered for immediate sale (free tonnage), and the amount that is held in reserve for later sale (the reserve pool), to control the overall supply of raisin grapes on the market.

Raisins that are produced organically are usually sold for a "bonus price", a premium price higher than the comparable conventional product. Returns to growers are on a per ton basis, and vary depending on a number of factors, including the agreement between a grower and his or her packer, crop maturity, quality and moisture, industry supply and consumer demand. Growers may not market or sell their product as organic during the transition years, and therefore cannot take advantage of potentially higher returns to offset the increased management and production risks 
during this time.

After harvest, both organic and conventional raisin grapes are delivered to one of two packer types for United States Department of Agriculture (USDA) inspection: 1) grower-owned cooperatives or 2) independent/commercial packers. Growers receive payment for their crop from the packer. Conceivably, each grower and packer could negotiate the price a grower receives. However, the structure of the industry is such that the Raisin Bargaining Association (RBA), a grower-owned bargaining collective, now sets the recognized field price for free tonnage for Thompson Seedless and Zante currant raisins. The price for the portion of the crop held in the reserve pool is known only after the reserve pool is sold. It is frequently, and often considerably, less than the field price. Therefore, growers seldom know the exact price they will receive for all delivered tonnage until much later in the year.

Unlike the price and tonnage structures set by the RBA and RAC, respectively, growers and packers negotiate the above mentioned bonus price on an individual basis. In the past, the bonus price has been offered for the entire crop, or both the free and reserve tonnage. Organic growers must, however, adhere to all other directives of the marketing order. In most cases, the packer retains control of the raisin crop for marketing purposes, however, a very small percentage of growers market their own product.

\section{Regulation of Organically Grown Commodities}

\section{State Registration}

Growers who choose to produce and market their crops as organic must register on a yearly basis with the State of California under the California Organic Foods Act of 1990. The law contains rules and regulations to which all producers, processors and handlers of organic commodities must adhere. As of January 1, 1996, in order to qualify as organic, commodities must be produced on land where no prohibited substances have been applied for a minimum of three years immediately preceding harvest of the crop. Annual registration fees are levied by the state and, in addition, a one-time initial registration fee is assessed. Fees are payable before any sales of the commodity occur and are based on projected estimates of gross receipts. The state program is administered through the California Department of Food and Agriculture (CDFA).

\section{Federal Regulations}

On October 1, 1993, the federal Organic Foods Production Act of 1990 (OFPA) became effective. This act sets forth production standards and regulates all organic commodities on the national level. However, because of budget and time constraints, final recommendations for the law's implementation have not been completed. Therefore, even though the law is now in place, implementation and enforcement have been delayed. Nevertheless, it would be prudent for growers to follow current recommendations for the federal law (in addition to state regulations) even before implementation and enforcement take place. The federal program is administered through the United States Department of Agriculture (USDA).

In most cases the OFPA will preempt state law except in those cases where the state applies to the USDA for approval of stricter standards. One difference between state and federal law is noteworthy. The federal law currently recommends that growers be certified by a federally accredited certifying agent on an annual basis if yearly gross sales total more than $\$ 5,000$. This federal requirement should not be confused with, and is separate from, state registration.

\section{Certification}

The best available statistics for organic agriculture show that during the 1992-1993 time period, $45 \%$ of California's registered organic farmers were also certified by a private certification agency. Of the $45 \%$ that were certified, $41 \%$ were certified by California Certified Organic 
Farmers (CCOF). In addition to CCOF, seven other organizations now actively certify growers in the state. They are: Farm Verified Organic (FVO), Oregon Tilth Certified Organically Grown (OTCO), Organic Certifiers (OC), the Organic Crop Improvement Association (OCIA), the Organic Growers and Buyers Association (OGBA), Quality Assurance International (QAI) and Scientific Certification Systems (SCS). Each agency must adhere to all state and federal laws regulating organic commodities, and in addition may enforce procedures specific to their own agencies. Organizations differ with respect to the certification process and associated costs. Domestic and international product sales may also be affected by certification itself, and by the certification agency used. The above organizations are registered with the State of California. However, none are currently accredited by the USDA since the USDA's certification program has not yet been implemented (additional sources of information are provided in the reference section of this publication).

\section{UNIVERSITY OF CALIFORNIA COOPERATIVE EXTENSION COST AND RETURNS STUDY FOR ORGANIC RAISIN GRAPES SOUTHERN SAN JOAQUIN VALLEY - 1997}

\section{General Information}

The practices described for the hypothetical organic vineyard used in this report are considered common for raisin grapes in the Southern San Joaquin Valley. Sample costs given for labor, materials, equipment and contract services are based on 1997 prices. The use of trade names is not an endorsement or a recommendation, nor is criticism implied by omission of similar products. A blank Your Cost column is provided to enter your actual costs on Table 1 Costs Per Acre - Operations and Table 2 Detail of Costs Per Acre - Inputs. Costs and practices detailed in this study may not be applicable to all situations. This study is only intended as a guide and can be used in making production decisions, determining potential returns, preparing budgets and evaluating production loans.

This report consists of the set of assumptions used for organic raisin grape production, along with the following six tables.

Table 1. Costs Per Acre - Operations

Table 2. Detail of Costs Per Acre - Inputs

Table 3. Monthly Cash Costs Per Acre

Table 4. Annual Equipment, Investment And Business Overhead Costs

Table 5. Hourly Equipment Costs

Table 6. Ranging Analysis

For an explanation of calculations used for this study refer to the attached assumptions, call the Department of Agricultural and Resource Economics, Cooperative Extension, University of California, Davis, California, (916) 752-9376 or call the farm advisor in the county of interest.

A study entitled Sample Costs to Establish a Vineyard and Produce Raisins in the San Joaquin Valley - 1997 is available for those interested in vineyard establishment costs and for production costs of conventionally grown raisin grapes.

Copies of this, and the above study, can be requested through the Department of Agricultural and Resource Economics, U.C. Davis, or from selected county Cooperative Extension offices.

\section{Cost of Production Assumptions For Organic Raisin Grapes}


This study reflects the practices and costs associated with a production system for organically grown raisin grapes in the Southern San Joaquin Valley of California. While every effort is made to model a production system based on real world practices, this report cannot fully represent the costs and practices that are specific to each vineyard or production region. This study should be interpreted as a representative operation only and not as a statistical average. Costs are presented on an annual per acre basis.

The vineyard in this report is assumed to have been established as a conventional vineyard for raisin grape production but is now registered and certified as organic. To be registered and certified organic, a transition period is required when any farm or production unit changes from conventional to organically acceptable practices. Federal, state and certification agency rules and regulations specific to organic commodities must be adhered to during this time period if crops are to be marketed as organic. Crops grown in transition years may not be sold or labeled as organic. Commodities that are produced organically can often be sold for a higher, premium price than conventionally grown products. However, the supply of organic products, market competition, and consumer demand will affect grower returns.

The following is a description of general assumptions pertaining to sample costs for organic raisin grapes.

\section{Land}

The total farm size is 120 acres, 80 of which are in raisin grape production. The remaining 40 acres are dedicated to other agricultural enterprises and land for the farmstead, roads and wells. Land is owned by the grower and is valued at $\$ 4,500$ per acre. This figure is within the low and high ranges of values for undeveloped land with vineyard potential in the Southern San Joaquin Valley. Land costs per acre vary within the region and within each county. Land is not depreciated. Land is assumed to be level, with well-drained soils of moderate depth and fertility.

\section{Vineyard Establishment}

The establishment cost is the sum of the costs for the land preparation, trellis system, planting, vines, cash overhead and production expenses for growing the vines through the first year that grapes are harvested (year three). The vineyard establishment cost is used to determine the noncash overhead expenses, capital recovery and interest on investment during the production years. (For more detailed information on this cost refer to the study Sample Costs To Establish A Vineyard And Produce Raisins in the San Joaquin Valley - 1997). The vineyard life is assumed to be 22 years beyond three establishment years.

\section{Vines/Trellis System}

The grape variety is assumed to be Thompson Seedless. Vines are planted on a 7' x 12' spacing with 519 vines per acre. The trellis system is a two-wire cross-arm design.

\section{Production Practices}

Production practices for organic raisin grapes are listed in Table 1 Costs Per Acre - Operations. This table shows the order in which the operations are performed, as well as the hours per acre required for each operation. Labor, contract and rental rates, materials, and fuel and repair costs are also included in this table. Input costs can be found in Table 2 Detail of Costs Per Acre Inputs. In addition, the sequence of operations and monthly cash costs per acre for the crop are located in Table 3 Monthly Cash Costs Per Acre.

\section{Cover Crops/Floor Management}

In this study, a winter annual cover crop is drill-seeded in the fall after harvest. Prior to seeding the cover crop, vineyard middles are re-leveled (terraced back), subsoiled (ripped 20 to 24") in 
every othe row and irrigated. Planting into moisture serves to improve stand establishment and early cover crop growth. After this time, cover crop growth is assumed to be dependent on fall and winter rains.

The cover crop is a mixture of common vetch and barley, which is planted into each middle in six-foot strips at a rate of 50 pounds per planted vineyard acre. This represents $50 \%$ of the seeding rate per acre to account for space taken up by the vine rows. This seeding rate also rerresents a mixture of the two species of cover crops (40 pounds of common vetch and 10 pounds of barley). It may be necessary to increase seeding rates for late season plantings to insure a good stand.

The cover crop is mowed in February in one-half of the vineyard in conjunction with shredding and chopping brush from pruning operations. In April, the entire cover crop is mowed once, and then incorporated into the soil by discing twice. Vineyard middles are disced three times during the remaining spring and summer months to control weeds. Therefore, no additional water is required for cover crop growth or for resident weeds during the summer.

Weeds in vine rows are controlled by mechanically cultivating with an in-row cultivator once in February, and by hand hoeing once in April. No other means of weed control are used in this report.

\section{Crop Irrigation}

The amount of irrigation water applied to vineyards in this region ranges from 2.5 to 4.5 acre-feet per acre per year, averaging a total of 3.5 acre-feet per acre. However, this amount is dependent on soil type, rainfall and residual soil moisture, and water availability. Raisin grapes are most typically furrow irrigated with a combination of district (surface) and well (pumped) water. The amount of water that is applied to the crop from each source is determined primarily by the availability of district water. In this study, approximately $60 \%$ (25 acre-inches) of the total applied water is delivered from the district; $40 \%$ (17 acre-inches) is pumped. No assumption is made with respect to effective rainfall.

In most districts, the cost for water is based on a flat tax rate, and ranges from $\$ 17$ to $\$ 38$ per acre, averaging about $\$ 25$ per acre. In the Madera area, delivery charges are incurred, and district water costs average $\$ 46$ per acre-foot. The cost included in this study for district water is $\$ 30$ per acre.

Costs for pumped water depend on well design, equipment and depth. In this study, water is assumed to be pumped from a depth of 130 feet in a 400-foot well using a 40 horsepower (hp) pump that produces a flow of 700 gallons per minute (gpm). The cost for pumped water is estimated to be $\$ 42$ per acre-foot. The vineyard is assumed to be irrigated after harvest in October, and during the growing season between April and August.

Costs for the furrow irrigation system include charges to refurbish the motor and pump, clean the well and install underground mainline pipe and risers for each vineyard row. The irrigation system has a 25 year lifespan, is an improvement to the property, and is therefore included in Table 4 as an investment.

\section{Pest Management}

Disease incidence and arthropod and vertebrate pest damage vary on a year-to-year basis depending on pest populations and management techniques. This study assumes that vineyards are monitored for disease, insect and mite pests periodically throughout the growing season by the grower or by an input supplier who is also a licensed pest control advisor (PCA). Therefore, no specific cost is incurred for monitoring services. The following table shows the pest management 
materiais usea in tnis report.

Pest Management Materials

\begin{tabular}{|c|c|c|c|}
\hline Material & $\begin{array}{l}\text { Number of } \\
\text { Applications }\end{array}$ & $\begin{array}{c}\text { Application Rate } \\
\text { Range/Acre }^{\dagger}\end{array}$ & Month(s) Performed \\
\hline Dusting Sulfur & 10 & $10-12 \mathrm{lbs}$ & March - July \\
\hline Wettable Sulfur ${ }^{\ddagger}$ & 2 & $2 \mathrm{lbs}$ & May, July \\
\hline Cryolite ${ }^{\ddagger}$ & 2 & $6 \mathrm{lbs}$ & May, July \\
\hline
\end{tabular}

$\dagger$ Application rates and months performed are those used in this study. Individual situations will vary.

¥ Wettable sulfur and cryolite are mixed and applied in one operation.

Many beneficial arthropods occur naturally within fully transitioned organic vineyards, therefore, growers do not necessarily release beneficial arthropods on a year-to-year basis. However, a number of growers do release beneficial arthropods each year, primarily predatory mites and green lacewings, to augment the levels that already exist in the field. The cost to purchase and release beneficial arthropods varies depending on the type and number purchased. It also depends on the number of acres treated and on field labor charges. Costs range from $\$ 35$ and $\$ 75$ per acre. A cost of $\$ 40$ per acre is included in this report.

\section{Harvest}

In this study, grapes are assumed to be hand harvested at a contract rate of $\$ 0.24$ per tray. Contract services are also used for turning, rolling and pick up ( $\$ 84$ per thousand trays), and for transporting raisins to a packer ( $\$ 10$ per ton). Labor and taxes are included in all of the above contract rates. Boxing and shaking raisins is performed by the grower. Harvest costs are located in Tables 1 through 3. Harvest begins in August and is completed in September.

Because contract services are assumed for most harvest operations, costs for harvest equipment (other than equipment to box and shake raisins) are not included in this study. If growers choose to perform all harvest operations, equipment for the appropriate operations should be inventoried and labor, fuel, repairs and capital recovery costs should be added as a cost of production.

Contract harvest costs, then, would not be included.

\section{Packers}

After harvest the crop is transported to a packer where it is inspected by a representative of the United States Department of Agriculture (USDA) for maturity, quality and moisture. Organic raisins must meet the same industry standards as the conventional crop to pass inspection.

Industry standards are set by the Raisin Administrative Committee (RAC), the administrative arm of the federal marketing order for raisins. Fees are associated with both USDA inspections and $\mathrm{RAC}$ administrative responsibilities; these are paid for by the packer. Growers receive payment for their crop from the packer. In most cases, the packer retains control of the raisin crop for marketing purposes after inspection, however, a very small number of growers market their own product.

\section{Yield and Return Ranges}

This study assumes a yield of 2.1 tons of raisins per acre in Tables 1 to 3 . Yields for organically grown raisins typically range from 1.5 to 3.0 tons per acre. Yield is determined by a variety of 
factors, including growing location and conditions, soil type and fertility, irrigation practices and pest management.

The price received by growers of organic raisins is estimated to be $\$ 1,175$ per ton, which is calculated by adding a per ton "organic bonus" price for $100 \%$ of the organic crop to a "constructed" per ton price for $100 \%$ of the conventional crop. The constructed per ton price on $100 \%$ of the conventional crop is based on tonnage percentages and values for both free tonnage and the reserve pool as announced by the Raisin Administrative Committee (RAC) and the Raisin Bargaining Association (RBA). In the past, constructed prices for the conventional crop have ranged from $\$ 800$ to $\$ 1,200$ per ton. For this study, the price is estimated to be $\$ 1,025$ per ton. The organic bonus price is negotiated between each grower and packer, and usually ranges from $\$ 100$ to $\$ 175$ per ton. The price of $\$ 1,175$ per ton therefore equals the estimated price of $\$ 1,025$ plus an organic bonus of $\$ 150$ per ton for $100 \%$ of the crop. However, the exact price each grower receives will vary depending on crop maturity, quality and moisture, and on the organic bonus price negotiated between the grower and packer.

For the raisin grape operation analyzed in this study, the breakeven yield at an average price of $\$ 1,175$ per ton is 1.8 tons per acre. Breakeven yields are 2.3 and 1.5 tons per acre at the low price of $\$ 950$ and at the high price of $\$ 1,350$ per ton, respectively.

\section{Labor}

Basic hourly wages for workers are $\$ 5.75$ and $\$ 5.00$ per hour for machine operators and field workers, respectively. Adding 34\% for workers compensation, social security, insurance and other benefits increases the labor rates shown to $\$ 7.71$ per hour for machine labor and $\$ 6.70$ per hour for non-machine labor. The percentage charged for benefits varies depending upon whether or not growers utilize labor contractors or hire their own laborers. For those growers handling their own labor, benefit percentages are often lower than $34 \%$, and have been as low as $18 \%$ in the past.

On March 1, 1997, the minimum wage increased from $\$ 4.25$ per hour to $\$ 5.00$ per hour. It will rise to $\$ 5.15$ per hour on September 1, 1997 and to $\$ 5.75$ per hour on March 1, 1998. The wage rate for non-machine labor used in this study reflects the March 1, 1997 rate. Growers using wage rates different from those shown in this report may adjust their labor costs by subtracting or adding the appropriate amounts.

The labor hours for operations involving machinery are $20 \%$ higher than the operation times listed on Table 1 to account for extra labor involved in equipment set-up, moving, maintenance, work breaks and repair. Wages for managers are not included as a cash cost. Any returns above total costs are considered returns to management and risk.

Cash Overhead. Cash overhead consists of various cash expenses paid out during the year that are assigned to the whole farm and not to a particular operation. These costs include, but are not limited to, property taxes, interest on operating capital, office expenses, property and liability insurance, sanitation services and equipment repairs. Cash overhead costs are found in Tables 1 through 4 .

Property Taxes. Counties charge a base property tax rate of $1 \%$ on the assessed value of the property. In some counties special assessment districts exist and additional taxes are charged on property including equipment, buildings and improvements. For this study, county taxes are calculated as $1 \%$ of the average value of the property. Average value equals new cost plus salvage value, divided by two, on a per acre basis.

Interest on Operating Capilal. Interest on operating capital is based on cash operating costs and is 
calculated monthly until harvest at a nominal rate of $10.00 \%$ per year. A nominal interest rate is the going market cost for borrowed funds. The short-term interest rate is calculated by the Production Credit Association using various criteria including a 2\% stock ownership.

Office and Business Expense. Office and business expenses are estimated at $\$ 12$ per acre. These expenses include, but are not limited to, office supplies, telephones, bookkeeping, accounting, legal fees and road maintenance.

Insurance. Insurance for farm investments varies depending on the assets included and the amount of coverage. Property insurance provides coverage for property loss and is charged at $0.713 \%$ of the average value of the assets over their useful life. Liability insurance covers accidents on the farm and costs $\$ 526$ per year.

Sanitation Services. Sanitation services (portable toilets) are provided by the contractor when contract labor is used. Because contract labor is assumed for many of the operations included in this study, the minimal cost of $\$ 100$ for santitation services is included here.

Crop Insurance. This study assumes that the grower pays a total of $\$ 46.70$ per ton for crop insurance. This rate includes $65 \%$ crop loss coverage under the federal crop insurance program ( $\$ 31$ per ton) and also includes a premium for reconditioning insurance ( $\$ 15.70$ per ton).

Non-Cash Overhead. Non-cash overhead is calculated as the capital recovery cost for equipment and other farm investments. Although farm equipment is often purchased used, this study shows the current purchase price for new equipment adjusted to $60 \%$ of the new value to indicate a mix of new and used equipment. Annual ownership costs for equipment and other investments are shown in Tables 1,2 and 4. They represent the capital recovery cost for each investment on an annual per acre basis.

Capital Recovery Costs. Capital recovery cost is the annual depreciation and interest cost for a capital investment. In other words, it is the amount of money required each year to recover the difference between the purchase price and salvage value, or unrecovered capital. Capital recovery cost is equivalent to the annual payment on a loan for an investment with the down payment equal to the discounted salvage value. This is a more complex method of calculating ownership costs than by using straight-line depreciation and opportunity costs. However, it more accurately represents the annual costs of ownership because it takes the time value of money into account. The calculation for annual capital recovery costs is as follows.

\section{[(Purchase Price - Salvage Value) x (Capital Recovery Factor)] + [Salvage Value x Interest Rate]}

Salvage Value. Salvage value is an estimate of the remaining market value of an investment at the end of its useful life. Salvage value is calculated differently for different investments. For farm machinery (tractors and other implements), the remaining value is a percentage of the new cost of the investment. Salvage value for farm equipment is calculated as follows.

\section{[New Price x \% Remaining Value]}

Salvage value for other investments including farm buildings, irrigation systems and miscellaneous tools and equipment is zero. The salvage value for land is equal to the purchase price because land does not depreciate. Purchase price and salvage value for the equipment and investments used in this study are shown on Table 4.

Capital Recovery Factor. The capital recovery factor is the amortization factor or annual payment whose present value at compound interest is equal to one. The capital recovery factor is 
a function of the interest rate and years of life of the equipment.

Interest Rate. An interest rate of $8.25 \%$ is used to calculate capital recovery costs. This interest rate is the United States Department of Agriculture Economic Research Service's (USDA-ERS's) ten year average of the agricultural sector long-run rate of return to production assets from current income. It is used to reflect the long-term realized rate of return to the specialized resources that can only be used effectively in the agricultural sector. In other words, the next best alternative use of these resources is in another agricultural enterprise.

Equipment Cash Costs. Equipment costs are composed of three parts: cash overhead, non-cash overhead and operating costs. Both of the overhead factors are detailed in previous sections. The operating costs consist of fuel, lubrication and repairs.

In allocating the equipment costs on a per acre basis, the following hourly charges are calculated first and shown in Table 5. Repair costs are based on the purchase price, annual hours of use, total hours of life and repair coefficients formulated by the American Society of Agricultural Engineers (ASAE). Fuel and lubrication costs are also determined by ASAE equations based on maximum power take-off (PTO) horsepower (hp) and the type of fuel used. The fuel and repair costs per acre for each operation in Table 1 are determined by multiplying the total hourly operating cost in Table 5 for each piece of equipment used for the cultural practice by the number of hours per acre for that operation. Tractor operation time is $10 \%$ higher than implement operation time to account for fueling, equipment moving and setup time. Prices for on-farm delivery of diesel and gasoline are $\$ 0.97$ and $\$ 1.30$ per gallon, respectively.

Assessments. In this study, registration and certification fees for an established organic vineyard are estimated and included as a cost of production. All organic growers who produce and market their crop as organic must pay state registration fees. Certification is currently optional for organic production, but in most cases will become mandatory upon implementation of the federal law. Certification fees for new operations may be higher than for established operations because of the initial certification and inspection process.

For comparison purposes, fees from two different certification organizations are listed below. However, only fees from California Certified Organic Farmers (CCOF) are included in the actual cost calculations of this study. The costs can be adjusted for Farm Verified Organic (FVO) growers by subtracting CCOF fees and adding FVO fees. Some growers have multiple certifications for marketing purposes. In this case, both sets of fees would be added.

California Department of Food and Agriculture (C.DFA) Organic Program. A stepped scale organic grower's registration fee of $\$ 300$ is assessed by the State of California on the gross sales amount of $\$ 197,400$. The gross sales amount is calculated by multiplying the yield of the crop per acre (2.1 tons) by the price received for the crop per ton $(\$ 1,175)$ and the number of planted acres for the crop (80). This is only an estimate of potential fees; they will vary depending on yields and returns. Contact the County Agricultural Commissioner in your area for further details.

California Certified Organic Farmers (CCOF). Annual membership fees are estimated to be $\$ 125$. Annual inspection fees are $\$ 250$. In addition, CCOF growers are also required to pay assessment fees of $0.5 \%$ of their gross sales. Total CCOF assessments for the 80 acres of raisin grapes in this study are $\$ 987$. Fees are based on the production amount, the number of acres and parcels contained in an operation as well as whether or not the farm is totally organic. Therefore, individual situations will vary.

Farm Verified Organic, Inc. (FVO). Fee structures for FVO vary depending on what category the operation qualifies under (e.g. Family Farm, Cottage Industry, Regular or Cooperative). For a 
grower in the FVO Family Farm category, the annual participation fee is $\$ 150$. Inspection costs are charged at $\$ 15$ per hour for travel and $\$ 39$ per hour for inspection and audit, plus expenses. In addition, growers pay a licensing fee of $0.5 \%$ on all FVO certified sales, or they may pursue a pass-through fee arrangement and pay nothing.

Acknowledgement. Appreciation is expressed to the growers and other individuals who provided information, assistance and expertise for this study.

This study was funded by the Clarence E. Heller Charitable Foundation and by the California Pesticide Impact Assessment Program.

\section{REFERENCES}

California Certified Organic Farmers, Inc. (CCOF). 1996. California Certified Organic Farmers Certification Handbook. California Certified Organic Farmers, Inc. Santa Cruz, California.

California Department of Food and Agriculture Organic Program. 1996. California Organic Program. Producing, Handling, and Processing Organic Products In California. California Department of Food and Agriculture Organic Program. Sacramento, California.

Chaney, David E., Laurie E. Drinkwater, and G. Stuart Pettygrove. 1992. Organic Soil Amendments and Fertilizers. UC Sustainable Agriculture Research \& Education Program. University of California, Division of Agriculture and Natural Resources. Oakland, California. Publication 21505.

Flint, Mary Louise. 1990. Pests of the Garden and Small Farm: A Grower's Guide to Using Less Pesticide. University of California, Statewide Integrated Pest Management Project, Division of Agriculture and Natural Resources. Oakland, California. Publication 3332.

Ingels, Chuck, Mark Van Horn, Robert L. Bugg and P. Rick Miller. 1994. Selecting the right cover crop gives multiple benefits. California Agriculture. 48(5):43-48.

Integrated Pest Management Education and Publications. 1992. U.C. IPM Pest Management Guidelines. University of California, Statewide Integrated Pest Management Project, Division of Agriculture and Natural Resources. Oakland, California. Publication 3339.

Klonsky, Karen and Laura Tourte. 1994. State Registration and Organic Certification: A Guide for California Growers. Department of Agricultural Economics, University of California. Davis, California.

Klonsky, Karen and Laura Tourte. 1995. Statistical Review for California's Organic Agriculture 1992-1993. Department of Agricultural Economics, University of California. Davis, California.

Miller, P.R., W.L. Graves, W.A. Williams, and B.A. Madson. 1989. Covercrops for California Agriculture. University of California, Division of Agriculture and Natural Resources. Oakland, California. Leaflet 21471.

Parnes, Robert. 1990. Fertile Soil: A Grower's Guide to Organic \& Inorganic Fertilizers. agAccess. Davis, California.

University of California Publications. 1992. Grape Pest Management. Second Edition. Division of Agriculture and Natural Resources. Oakland, California. 
Publication 3343.

United States Department of Agriculture. 1996. Noncitrus Fruits and Nuts 1995 Summary. United States Department of Agriculture. National Agricultural Statisitics Service. Washingston D.C.

United States Department of Agriculture. 1997. Noncitrus Fruits and Nuts 1996 Preliminary Summary. United States Department of Agriculture.

\section{Other Sources of Information}

National Agricultural Statisitics Service. Washingston D.C.

Organic Cost Study: Organic Wine Grapes--With an Annual Sown Cover Crop, North Coast (1992)

For more information about SAREP email link.

[ Home $\mid$ Search $\mid$ Feedback ]

This page was last changed on Monday, June 01, 1998 11:41:31 
U.C. COOPERATIVE EXTENSION

Table 1. COSTS PER ACRE TO PRODUCE ORGANIC RAISIN GRAPES -

OPERATIONS

SOUTHERN SAN JOAQUIN VALLEY - 1997

Labor Rate:

$\$ 7.71 / \mathrm{hr}$. machine labor

Interest Rate:

$10.00 \%$

$\$ 6.70 / \mathrm{hr}$. non-machine

Yield per Acre:

2.10 ton

labor

\begin{tabular}{|c|c|c|c|c|c|c|c|}
\hline & & \multicolumn{6}{|c|}{ Cash and Labor Costs per Acre } \\
\hline Operation & $\begin{array}{c}\text { Operation } \\
\text { Time } \\
\text { (Hrs/A) }\end{array}$ & $\begin{array}{c}\text { Labor } \\
\text { Cost }\end{array}$ & $\begin{array}{c}\text { Fuel, } \\
\text { Lube } \\
\& \\
\text { Repairs }\end{array}$ & $\begin{array}{l}\text { Material } \\
\text { Cost }\end{array}$ & Custom/Rent & $\begin{array}{l}\text { Total } \\
\text { Cost }\end{array}$ & $\begin{array}{l}\text { Your } \\
\text { Cost }\end{array}$ \\
\hline Cultural & & & & & & & \\
\hline Terrace Back & 0.25 & 2.31 & 1.17 & 0.00 & 0.00 & 3.49 & \\
\hline Subsoil - $1 / 2$ Acres & 0.50 & 4.63 & 2.79 & 0.00 & 0.00 & 7.42 & \\
\hline $\begin{array}{l}\text { Disc - Prepare } \\
\text { Seedbed }\end{array}$ & 0.20 & 1.85 & 1.16 & 0.00 & 0.00 & 3.01 & \\
\hline Furrow Out & 0.86 & 7.94 & 3.99 & 0.00 & 0.00 & 11.93 & \\
\hline Postharvest Irrigaticn & 0.50 & 3.35 & 0.00 & 14.16 & 0.00 & 17.51 & \\
\hline $\begin{array}{l}\text { Plant Cover Crop - } \\
\text { Drill Seed }\end{array}$ & 0.50 & 4.63 & 2.84 & 22.70 & 0.00 & 30.16 & \\
\hline Pruning & 0.00 & 0.00 & 0.00 & 0.00 & 124.56 & 124.56 & \\
\hline Vineyard Maintenance & 1.00 & 15.95 & 4.61 & 0.00 & 31.14 & 51.70 & \\
\hline Shred/Chop Brush & 0.13 & 1.16 & 0.70 & 0.00 & 0.00 & 1.86 & \\
\hline Cultivate In Row & 0.74 & 6.80 & 3.88 & 0.00 & 0.00 & 10.69 & \\
\hline $\begin{array}{l}\text { Sulfur Application } \\
10 \mathrm{X}\end{array}$ & 1.25 & 11.57 & 6.03 & 18.02 & 0.00 & $35.62^{\prime}$ & \\
\hline Mow Cover Crop & 0.20 & 1.85 & 1.12 & 0.00 & 0.00 & 2.97 & \\
\hline $\begin{array}{l}\text { Disc } 2 \mathrm{X} \text { - Incorporate } \\
\text { Cover Crop }\end{array}$ & 0.40 & 3.70 & 2.31 & 0.00 & 0.00 & 6.01 & \\
\hline Border Disc & 0.14 & 1.32 & 0.81 & 0.00 & 0.00 & 2.13 & \\
\hline Hand Hoe & 1.20 & 8.04 & 0.00 & 0.00 & 0.00 & 8.04 & \\
\hline Irrigation $6 \mathrm{X}$ & 4.98 & 33.37 & 0.00 & 76.02 & 0.00 & 109.39 & \\
\hline
\end{tabular}

file://D:\Afghanistan\Raisins $\$ Economics of Producing Organic Raisins.htm 


\begin{tabular}{|c|c|c|c|c|c|c|}
\hline $\begin{array}{l}\text { Insect Spray/Sulfur } \\
\text { Application }\end{array}$ & 0.50 & 4.63 & 3.13 & 34.40 & 0.00 & 42.15 \\
\hline $\begin{array}{l}\text { Beneficial Insects - } \\
\text { Release }\end{array}$ & 0.10 & 0.67 & 0.00 & 40.00 & 0.00 & 40.67 \\
\hline $\begin{array}{l}\text { Disc } 3 \mathrm{X} \text { - Floor } \\
\text { Management }\end{array}$ & 0.60 & 5.55 & 3.32 & 0.00 & 0.00 & 8.87 \\
\hline Terrace & 0.25 & 2.31 & 1.17 & 0.00 & 0.00 & 3.49 \\
\hline Pickup Use & 2.38 & 21.97 & 9.44 & 0.00 & 0.00 & 31.42 \\
\hline $\begin{array}{l}\text { TOTAL CULTURAL } \\
\text { COSTS }\end{array}$ & 16.67 & 143.59 & 48.47 & 205.30 & 155.70 & 553.07 \\
\hline \multicolumn{7}{|l|}{ Harvest: } \\
\hline Harvest - Contract & 0.00 & 0.00 & 0.00 & 46.50 & 223.20 & 269.70 \\
\hline $\begin{array}{l}\text { Turn \& Roll - } \\
\text { Contract }\end{array}$ & 0.00 & 0.00 & 0.00 & 0.00 & 78.12 & 78.12 \\
\hline Box \& Shake & 0.60 & 37.36 & 2.76 & 0.00 & 8.25 & 48.37 \\
\hline Haul To Packer & 0.00 & 0.00 & 0.00 & 0.00 & 21.00 & 21.00 \\
\hline $\begin{array}{l}\text { TOTAL HARVEST } \\
\text { COSTS }\end{array}$ & 0.60 & 37.36 & 2.76 & 46.50 & 330.57 & 417.19 \\
\hline \multicolumn{7}{|l|}{ Assessments } \\
\hline $\begin{array}{l}\text { California State } \\
\text { Organic Registration } \\
\text { Fees }\end{array}$ & 0.00 & 0.00 & 0.00 & 3.75 & 0.00 & 3.75 \\
\hline $\begin{array}{l}\text { CCOF Membership } \\
\text { Fees }\end{array}$ & 0.00 & 0.00 & 0.00 & 1.04 & 0.00 & 1.04 \\
\hline CCOF Inspection Fees & 0.00 & 0.00 & 0.00 & 2.08 & 0.00 & 2.08 \\
\hline $\begin{array}{l}\text { CCOF . } 5 \% \text { of Gross } \\
\text { Sales }\end{array}$ & 0.00 & 0.00 & 0.00 & 12.34 & 0.00 & 12.34 \\
\hline $\begin{array}{l}\text { TOTAL } \\
\text { ASSESSMENT } \\
\text { COSTS }\end{array}$ & 0.00 & 0.00 & 0.00 & 19.21 & 0.00 & 19.21 \\
\hline $\begin{array}{l}\text { Interest on operating } \\
\text { capital @10.00\% }\end{array}$ & & & & & & 27.66 \\
\hline $\begin{array}{l}\text { TOTAL } \\
\text { OPERATING } \\
\text { COSTS/ACRE }\end{array}$ & & 180.96 & 51.23 & 271.01 & 486.27 & 1017.12 \\
\hline \multicolumn{7}{|l|}{ CASH OVERHEAD: } \\
\hline Office Expense & & & & & & 12.00 \\
\hline
\end{tabular}




\begin{tabular}{|c|c|c|c|}
\hline Soil/Tissue Analysis & & & 2.95 \\
\hline Liability Insurance & & & 4.38 \\
\hline Sanitation Services & & & 1.25 \\
\hline Crop Insurance & & & 98.07 \\
\hline Property Taxes & & & 68.71 \\
\hline Property Insurance & & & 48.99 \\
\hline Investment Repairs & & & 11.54 \\
\hline $\begin{array}{l}\text { TOTAL CASH } \\
\text { OVERHEAD COSTS }\end{array}$ & & & 247.89 \\
\hline $\begin{array}{l}\text { TOTAL CASH } \\
\text { COSTS/ACRE }\end{array}$ & & & 1265.02 \\
\hline \multicolumn{4}{|l|}{$\begin{array}{l}\text { NON-CASH } \\
\text { OVERHEAD: }\end{array}$} \\
\hline Investment & $\begin{array}{c}\text { Per } \\
\text { producing } \\
\text { Acre }\end{array}$ & $\begin{array}{c}\text { Annual } \\
\text { Cost } \\
\text { Capital } \\
\text { Recovery }\end{array}$ & \\
\hline Buildings & 143.33 & 13.03 & 13.03 \\
\hline Shop tools & 41.67 & 4.94 & 4.94 \\
\hline Land & 4500.00 & 371.25 & 371.25 \\
\hline $\begin{array}{l}\text { Vineyard } \\
\text { Establishment }\end{array}$ & 3839.00 & 383.81 & 383.81 \\
\hline Irrigation System & 187.08 & 17.90 & 17.90 \\
\hline Equipment & 427.70 & 57.52 & 57.52 \\
\hline $\begin{array}{l}\text { TOTAL NON-CASH } \\
\text { OVERHEAD COSTS }\end{array}$ & 9138.78 & 848.47 & 848.47 \\
\hline $\begin{array}{l}\text { TOTAL } \\
\text { COSTS/ACRE }\end{array}$ & & & 2113.48 \\
\hline
\end{tabular}

Return to Document

U.C. COOPERATIVE EXTENSION

Table 2. DETAIL OF COSTS PER ACRE TO PRODUCE ORGANIC RAISIN GRAPES INPUTS SOUTHERN SAN JOAQUIN VALLEY - 1997 
$\$ 6.70 / \mathrm{hr}$. non-machine labor

\begin{tabular}{|c|c|c|c|c|c|}
\hline & Quantity/Acre & Unit & $\begin{array}{l}\text { Price or } \\
\text { Cost/Unit }\end{array}$ & $\begin{array}{l}\text { Value or } \\
\text { Cost/Acre }\end{array}$ & $\begin{array}{l}\text { Your } \\
\text { Cost }\end{array}$ \\
\hline \multicolumn{6}{|l|}{ OPERATING COSTS } \\
\hline \multicolumn{6}{|l|}{ Water: } \\
\hline Pumped & 17.00 & $\operatorname{acin}$ & 3.54 & 60.18 & \\
\hline District & 25.00 & $a \operatorname{cin}$ & 1.20 & 30.00 & \\
\hline \multicolumn{6}{|l|}{ Cover Crop Seed } \\
\hline Common Vetch & 40.00 & $\mathrm{lb}$ & 0.52 & 20.80 & \\
\hline Barley & 10.00 & $\mathrm{lb}$ & 0.19 & 1.90 & \\
\hline \multicolumn{6}{|l|}{ Contract: } \\
\hline Prune & 519.00 & vine & 0.24 & 124.56 & \\
\hline Tie Canes & 519.00 & vine & 0.06 & 31.14 & \\
\hline Harvest & 930.00 & tray & 0.24 & 223.20 & \\
\hline Turn \& Roll & 0.93 & thousand & 84.00 & 78.12 & \\
\hline Haul to Packer & 2.10 & ton & 10.00 & 21.00 & \\
\hline \multicolumn{6}{|l|}{ Pest Management: } \\
\hline Dusting Sulfur & 106.00 & $\mathrm{lb}$ & 0.17 & 18.02 & \\
\hline Cryolite & 12.00 & $\mathrm{lb}$ & 2.68 & 32.16 & \\
\hline Wettable Sulfur & 4.00 & lb & 0.56 & 2.24 & \\
\hline Beneficial Insects & 1.00 & acre & 40.00 & 40.00 & \\
\hline \multicolumn{6}{|l|}{ Miscellaneous: } \\
\hline Paper Trays & 0.93 & thousand & 50.00 & 46.50 & \\
\hline \multicolumn{6}{|l|}{ Rent: } \\
\hline Forklif & 2.00 & acte & 4.12 & 8.25 & \\
\hline \multicolumn{6}{|l|}{ Assessment: } \\
\hline CA St. Org. Reg. Fees & 1.00 & acre & 3.75 & 3.75 & \\
\hline
\end{tabular}




\begin{tabular}{|c|c|c|c|c|}
\hline $\begin{array}{l}\text { CCOF Membership } \\
\text { Fees }\end{array}$ & 1.00 & acre & 1.04 & 1.04 \\
\hline CCOF Inspection Fees & 1.00 & acre & 2.08 & 2.08 \\
\hline CCOF . $5 \%$ Gross Sales & 1.00 & acre & 12.34 & 12.34 \\
\hline Labor (machine) & 12.58 & hrs & 7.71 & 97.01 \\
\hline Labor (non-machine) & 12.53 & hrs & 6.70 & 83.95 \\
\hline Fuel - Gas & 4.46 & gal & 1.30 & 5.79 \\
\hline Fuel - Diesel & 25.05 & gal & 0.97 & 24.30 \\
\hline Lube & & & & 4.52 \\
\hline Machinery repair & & & & 16.61 \\
\hline $\begin{array}{l}\text { Interest on operating } \\
\text { capital @10.00\% }\end{array}$ & & & & 27.66 \\
\hline $\begin{array}{l}\text { TOTAL OPERATING } \\
\text { COSTS/ACRE }\end{array}$ & & & & 1017.12 \\
\hline \multicolumn{5}{|l|}{$\begin{array}{l}\text { CASH OVERHEAD } \\
\text { COSTS: }\end{array}$} \\
\hline Office Expense & & & & 12.00 \\
\hline Soil/Tissue Analysis & & & & 2.95 \\
\hline Liability Insurance & & & & 4.38 \\
\hline Sanitation Services & & & & 1.25 \\
\hline Crop Insurance & & & & 98.07 \\
\hline Property Taxes & & & & 68.71 \\
\hline Property Insurance & & & & 48.99 \\
\hline Investment Repairs & & & & 11.54 \\
\hline $\begin{array}{l}\text { TOTAL CASH } \\
\text { OVERHEAD } \\
\text { COSTS/ACRE }\end{array}$ & & & & 247.89 \\
\hline $\begin{array}{l}\text { TOTAL CASH } \\
\text { COSTS/ACRE }\end{array}$ & & & & 1265.02 \\
\hline \multicolumn{5}{|l|}{$\begin{array}{l}\text { NON-CASH } \\
\text { OVERHEAD COSTS } \\
\text { (CAPITAL } \\
\text { RECOVERY): }\end{array}$} \\
\hline Buildings & & & & 13.03 \\
\hline
\end{tabular}




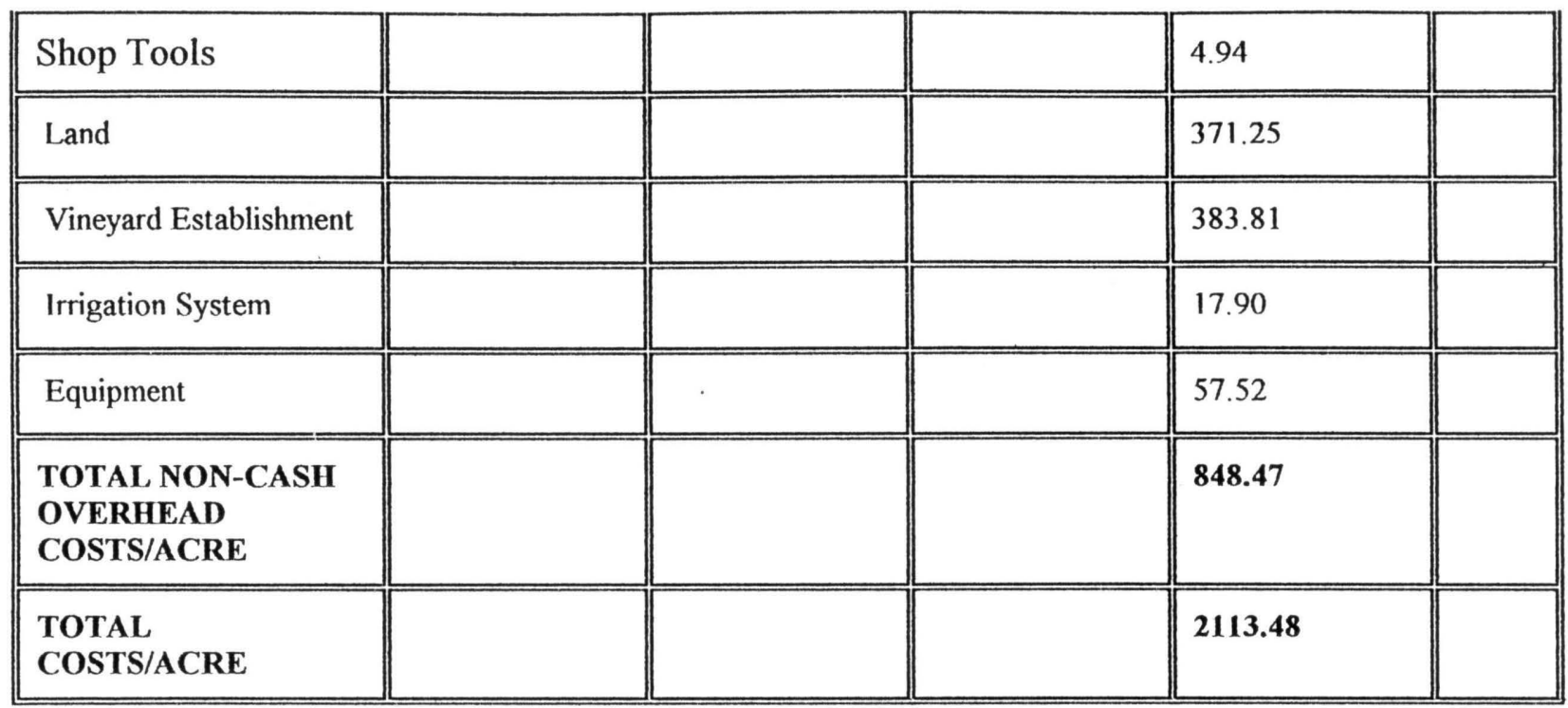

\section{Return to Document}

\section{U.C. COOPERATIVE EXTENSION}

Table 3. MONTHLY CASH COSTS PER ACRE TO PRODUCE ORGANIC RAISIN GRAPES SOUTHERN SAN JOAQUIN VALLEY - 1997

\begin{tabular}{|c|c|c|c|c|c|c|c|c|c|c|c|}
\hline $\begin{array}{l}\text { Beginning } \\
\text { OCT } 96 \\
\text { Ending SEP } 97\end{array}$ & $\begin{array}{c}\text { OCT } \\
96\end{array}$ & $\begin{array}{l}\text { NOV } \\
96\end{array}$ & $\begin{array}{c}\text { DEC } \\
97\end{array}$ & $\begin{array}{c}\text { JAN } \\
97\end{array}$ & $\begin{array}{c}\text { FEB } \\
97\end{array}$ & $\begin{array}{c}\text { MAR } \\
97\end{array}$ & $\begin{array}{c}\text { APR } \\
97\end{array}$ & $\underset{97}{\text { MAY }}$ & $\begin{array}{c}\text { JUN } \\
97\end{array}$ & $\begin{array}{c}\text { JUL } \\
97\end{array}$ & $\begin{array}{c}\text { AUC } \\
97\end{array}$ \\
\hline \multicolumn{12}{|l|}{ Cultural: } \\
\hline Terrace Back & 3.49 & & & & & & & & & & \\
\hline $\begin{array}{l}\text { Subsoil-1/2 } \\
\text { Acres }\end{array}$ & 7.42 & & & & & & & & & & \\
\hline $\begin{array}{l}\text { Disc-Prepare } \\
\text { Seedbed }\end{array}$ & 3.01 & & & & & & & & & & \\
\hline Furrow Out & 1.99 & & & & & & 1.99 & 1.99 & 3.98 & & 1.99 \\
\hline $\begin{array}{l}\text { Postharvest } \\
\text { Irrigation }\end{array}$ & 17.51 & & & & & & & & & & \\
\hline $\begin{array}{l}\text { Plant Cov. } \\
\text { Crop-Drill Seed }\end{array}$ & 30.16 & & & & & & & & & & \\
\hline Pruning & & & 62.16 & 62.40 & & & & & & & \\
\hline $\begin{array}{l}\text { Vineyard } \\
\text { Maintenance }\end{array}$ & & & & 51.70 & & & & & & & \\
\hline $\begin{array}{l}\text { Shred/Chop } \\
\text { Brush }\end{array}$ & & & & & 1.86 & & & & & & \\
\hline
\end{tabular}




\begin{tabular}{|c|c|c|c|c|c|c|c|c|c|c|c|}
\hline $\begin{array}{l}\text { Cultivate In } \\
\text { Row }\end{array}$ & & & & & 10.69 & & & & & & \\
\hline $\begin{array}{l}\text { Sulfur } \\
\text { Application 10X }\end{array}$ & & & & & & 3.80 & 11.06 & 6.92 & 10.38 & 3.46 & \\
\hline $\begin{array}{l}\text { Mow Cover } \\
\text { Crop }\end{array}$ & & & & & & & 2.97 & & & & \\
\hline $\begin{array}{l}\text { Disc } 2 \text { X-Incorp. } \\
\text { Cov. Crop }\end{array}$ & & & & & & & 6.01 & & & & \\
\hline Border Disc & & & & & & & 2.13 & & & & \\
\hline Hand Hoe & & & & & & & 8.04 & & & & \\
\hline Irrigation $6 \mathrm{X}$ & & & & & & & 28.57 & 13.06 & 26.12 & 13.06 & 28.57 \\
\hline $\begin{array}{l}\text { Insect } \\
\text { Spray/Sulfur } \\
\text { Appl. }\end{array}$ & & & & & & & & 21.08 & & 21.08 & \\
\hline $\begin{array}{l}\text { Beneficial } \\
\text { Insects-Release }\end{array}$ & & & & & & & & 40.67 & & & \\
\hline $\begin{array}{l}\text { Disc } 3 X \text {-Floor } \\
\text { Management }\end{array}$ & & & & & & & & & 2.93 & 3.01 & 2.93 \\
\hline Terrace & & & & & & & & & & & 3.49 \\
\hline Pickup Use & 2.62 & 2.62 & 2.62 & 2.62 & 2.62 & 2.62 & 2.62 & 2.62 & 2.62 & 2.62 & 2.62 \\
\hline $\begin{array}{l}\text { TOTAL } \\
\text { CULTURAL } \\
\text { COSTS }\end{array}$ & 66.19 & 2.62 & 64.78 & 116.72 & 15.16 & 6.42 & 63.39 & 86.33 & 46.03 & 43.22 & 39.60 \\
\hline \multicolumn{12}{|l|}{ Harvest: } \\
\hline $\begin{array}{l}\text { Harvest - } \\
\text { Contract }\end{array}$ & & & & & & & & & & & 134.6 \\
\hline $\begin{array}{l}\text { Turn \& Roll - } \\
\text { Contract }\end{array}$ & & & & & & & & & & & 38.64 \\
\hline Box \& Shake & & & & & & & & & & & 24.15 \\
\hline Haul To Packer & & & & & & & & & & & 10.50 \\
\hline $\begin{array}{l}\text { TOTAL } \\
\text { HARVEST } \\
\text { COSTS }\end{array}$ & & & & & & & & & & & 207.8 \\
\hline \multicolumn{12}{|l|}{ Assessments: } \\
\hline $\begin{array}{l}\text { CA St. Org. } \\
\text { Reg. Fees }\end{array}$ & & & & & & & & & & & \\
\hline
\end{tabular}




\begin{tabular}{|c|c|c|c|c|c|c|c|c|c|c|c|}
\hline $\begin{array}{l}\text { CCOF } \\
\text { Membership } \\
\text { Fees }\end{array}$ & & & & & & & & & & 1 & \\
\hline $\begin{array}{l}\text { CCOF } \\
\text { Inspection Fees }\end{array}$ & & & & & & & & & & & \\
\hline $\begin{array}{l}\text { CCOF .5\% of } \\
\text { Gross Sales }\end{array}$ & & & & & & & & & & & \\
\hline $\begin{array}{l}\text { TOTAL } \\
\text { ASSESSMENT } \\
\text { COSTS }\end{array}$ & & & & & & & & & & & \\
\hline $\begin{array}{l}\text { Interest on oper. } \\
\text { capital }\end{array}$ & 0.55 & 0.57 & 1.11 & 2.09 & 2.21 & 2.27 & 2.79 & 3.51 & 3.90 & 4.26 & 6.32 \\
\hline $\begin{array}{l}\text { TOTAL } \\
\text { OPERATING } \\
\text { COSTS/ACRE }\end{array}$ & 66.74 & 3.19 & 65.89 & 118.80 & 17.37 & 8.68 & 66.18 & 89.85 & 49.93 & 47.48 & 253.8 \\
\hline $\begin{array}{l}\text { CASH } \\
\text { OVERHEAD: }\end{array}$ & & & & & & & & & & & \\
\hline Office Expense & 1.00 & 1.00 & 1.00 & 1.00 & 1.00 & 1.00 & 1.00 & 1.00 & 1.00 & 1.00 & 1.00 \\
\hline $\begin{array}{l}\text { Soil/Tissue } \\
\text { Analysis }\end{array}$ & & & & & & & & 2.95 & & & \\
\hline $\begin{array}{l}\text { Liability } \\
\text { Insurance }\end{array}$ & & & & & & & & & & & \\
\hline $\begin{array}{l}\text { Sanitation } \\
\text { Services }\end{array}$ & 0.10 & 0.10 & 0.10 & 0.10 & 0.10 & 0.10 & 0.10 & 0.10 & 0.10 & 0.10 & 0.10 \\
\hline Crop Insurance & & & & & & & & & & & \\
\hline Property Taxes & & & 34.35 & & & & 34.35 & & & & \\
\hline $\begin{array}{l}\text { Property } \\
\text { Insurance }\end{array}$ & & & & 48.99 & & & & & & & \\
\hline $\begin{array}{l}\text { Investment } \\
\text { Repairs }\end{array}$ & 0.96 & 0.96 & 0.96 & 0.96 & 0.96 & 0.96 & 0.96 & 0.96 & 0.96 & 0.96 & 0.96 \\
\hline $\begin{array}{l}\text { TOTAL CASH } \\
\text { OVERHEAD } \\
\text { COSTS }\end{array}$ & 2.07 & 2.07 & 36.42 & 51.06 & 2.07 & 2.07 & 36.42 & 5.02 & 2.07 & 2.07 & 2.07 \\
\hline $\begin{array}{l}\text { TOTAL CASH } \\
\text { COSTS/ACRE }\end{array}$ & 68.80 & 5.26 & 102.31 & 169.86 & 19.44 & 10.75 & 102.60 & 94.86 & 51.99 & 49.54 & 255.8 \\
\hline
\end{tabular}

Return to Document

U.C. COOPERATIVE EXTENSION

Table 4. WHOLE FARM ANNUAL EQUIPMENT, INVESTMENT, AND BUSINESS OVERHEAD COSTS FOR ORGANIC RAISIN GRAPE PRODUCTION 


\section{SOUTHERN SAN JOAQUIN VALLEY - 1997}

\section{ANNUAL EQUIPMENT COSTS}

\begin{tabular}{|c|c|c|c|c|c|c|c|c|}
\hline \multirow{2}{*}{$\overline{\mathrm{Yr}}$} & \multirow[b]{2}{*}{ Description } & \multirow[b]{2}{*}{ Price } & \multirow[b]{2}{*}{ Yrs Life } & \multirow[b]{2}{*}{$\begin{array}{l}\text { Salvage } \\
\text { Value }\end{array}$} & \multirow[b]{2}{*}{$\begin{array}{l}\text { Capital } \\
\text { Recovery }\end{array}$} & \multicolumn{2}{|c|}{ Cash Overhead } & \multirow[b]{2}{*}{ Total } \\
\hline & & & & & & Insurance & Taxes & \\
\hline 97 & $\begin{array}{l}50 \mathrm{HP} 2 \mathrm{WD} \\
\text { Tractor }\end{array}$ & 29923 & 12 & 7481 & 3633.81 & 133.35 & 187.02 & 3954.18 \\
\hline 97 & $\begin{array}{l}75 \text { HP 2WD } \\
\text { Tractor }\end{array}$ & 33247 & 12 & 8312 & 4037.48 & 148.16 & 207.80 & 4393.44 \\
\hline 97 & $\begin{array}{l}\text { Air/Fan } \\
\text { Sprayer }\end{array}$ & 11130 & 10 & 1968 & 1543.20 & 46.69 & 65.49 & 1655.38 \\
\hline 97 & $\begin{array}{l}\text { Brush Shredder } \\
6^{\prime}\end{array}$ & 5721 & 10 & 1012 & 793.20 & 24.00 & 33.66 & 850.86 \\
\hline 97 & Disc - Border & 2876 & 10 & 509 & 398.73 & 12.07 & 16.92 & 427.72 \\
\hline 97 & $\begin{array}{l}\text { Disc - Tandem } \\
7\end{array}$ & 3729 & 10 & 659 & 517.06 & 15.64 & 21.94 & 554.64 \\
\hline 97 & Drill Seeder 5' & 2413 & 10 & 427 & 334.55 & 10.12 & 14.20 & 358.87 \\
\hline 97 & Duster & 2520 & 10 & 446 & 349.38 & 10.57 & 14.83 & 374.78 \\
\hline 97 & Flat Furrower & 1494 & 10 & 264 & 207.16 & 6.27 & 8.79 & 222.22 \\
\hline 97 & $\begin{array}{l}\text { In-Row } \\
\text { Cultivator }\end{array}$ & 3910 & 10 & 691 & 542.16 & 16.40 & 23.01 & 581.57 \\
\hline 97 & Pick up - $1 / 2$ ton & 16226 & 7 & 6155 & 2458.72 & 79.79 & 111.91 & 2650.42 \\
\hline 97 & $\begin{array}{l}\text { Shaker \& Bin } \\
\text { Dumper }\end{array}$ & 12870 & 10 & 2276 & 1784.44 & 54.00 & 75.73 & 1914.17 \\
\hline 97 & $\begin{array}{l}\text { Subsoiler - } 3 \\
\text { Shank }\end{array}$ & 1791 & 10 & 317 & 248.31 & 7.52 & 10.54 & 266.37 \\
\hline 97 & Terracer & 2465 & 10 & 436 & 341.77 & 10.34 & 14.51 & 366.62 \\
\hline 97 & Trailer \#1 & 1287 & 12 & 178 & 163.76 & 5.22 & 7.33 & 176.31 \\
\hline 97 & Trailer \#2 & 1287 & 12 & 178 & 163.76 & 5.22 & 7.33 & 176.31 \\
\hline \multicolumn{2}{|c|}{ TOTAL } & 132889 & & 31309 & 17517.49 & 585.36 & 821.01 & 18923.86 \\
\hline \multicolumn{2}{|c|}{$60 \%$ of New Cost $*$} & 79733 & & 18785 & 10510.49 & 351.22 & 492.61 & 11354.32 \\
\hline
\end{tabular}

* Used to reflect a mix of new and used equipment.

\section{ANNUAL INVESTMENT COSTS}




\begin{tabular}{|c|c|c|c|c|c|c|c|}
\hline & & & & & \multicolumn{3}{|c|}{ Cash Overhead } \\
\hline Description & Price & Yrs Life & $\begin{array}{l}\text { Salvage } \\
\text { Value }\end{array}$ & $\begin{array}{l}\text { Capital } \\
\text { Recovery }\end{array}$ & Insurance & Taxes & Rep. \\
\hline INVESTMENT & & & & & & & \\
\hline Buildings & 17200 & 30 & & 1564.01 & 61.32 & 86.00 & 100.0 \\
\hline $\begin{array}{l}\text { Vineyard } \\
\text { Establishment }\end{array}$ & 307120 & 22 & & 30705.20 & 1094.88 & 1535.60 & 0.00 \\
\hline $\begin{array}{l}\text { Irrigation } \\
\text { System }\end{array}$ & 22450 & 25 & & 2148.18 & 80.03 & 112.25 & 1235. \\
\hline Land & 540000 & & 540000 & 44550.00 & 3850.20 & 5400.00 & 0.00 \\
\hline Shop tools & 5000 & 15 & & 593.09 & 17.82 & 25.00 & 50.00 \\
\hline $\begin{array}{l}\text { TOTAL } \\
\text { INVESTMENT }\end{array}$ & 891770 & & 540000 & 79560.48 & 5104.25 & 7158.85 & 1385. \\
\hline
\end{tabular}

ANNUAL BUSINESS OVERHEAD COSTS

\begin{tabular}{||l||l|l||l||l||}
\hline Description & \multicolumn{1}{|c|}{ Units/Farm } & \multicolumn{1}{|c|}{ Unit } & \multicolumn{1}{|c|}{ Price/Unit } & Total Cost \\
\hline \hline Crop Insurance & $16 \overline{8} .00$ & ton & 46.70 & $7 \overline{8} 45.60$ \\
\hline \hline Liability Insurance & 1.00 & year & 526.00 & 526.00 \\
\hline \hline Office Expense & 80.00 & acre & 12.00 & 960.00 \\
\hline \hline Sanitation Services & 1.00 & farm & 100.00 & 100.00 \\
\hline \hline Soil/Tissue Analysis & 80.00 & acre & 2.95 & 236.00 \\
\hline
\end{tabular}

\section{Return to Document}

U.C. COOPERATIVE EXTENSION

Table 5. HOURLY EQUIPMENT COSTS FOR ORGANIC RAISIN GRAPE PRODUCTION SOUTHERN SAN JOAQUIN VALLEY - 1997

\begin{tabular}{|c|c|c|c|c|c|c|c|c|c|}
\hline & & & \multicolumn{7}{|c|}{ COSTS PER HOUR } \\
\hline & & & & \multicolumn{2}{|c|}{ Cash Overhead } & \multicolumn{3}{|c|}{ Operating } & \multirow[b]{2}{*}{$\begin{array}{c}\text { Total } \\
\text { Costs/Hr. }\end{array}$} \\
\hline $\mathbf{Y r}$ & Description & $\begin{array}{l}\text { Actual } \\
\text { Hours } \\
\text { Used* }\end{array}$ & $\begin{array}{l}\text { Capital } \\
\text { Recovery }\end{array}$ & Insurance & Taxes & Repairs & $\begin{array}{c}\text { Fuel } \\
\text { \&Lube }\end{array}$ & $\begin{array}{l}\text { Total } \\
\text { Oper. }\end{array}$ & \\
\hline
\end{tabular}




\begin{tabular}{|c|c|c|c|c|c|c|c|c|c|}
\hline 97 & $\begin{array}{l}50 \mathrm{HP} \\
2 \mathrm{WD} \\
\text { Tractor }\end{array}$ & 999.5 & 2.18 & 0.08 & 0.11 & 1.27 & 2.74 & 4.01 & 6.39 \\
\hline 97 & $\begin{array}{l}75 \mathrm{HP} \\
2 \mathrm{WD} \\
\text { Tractor }\end{array}$ & 999.2 & 2.42 & 0.09 & 0.12 & 0.61 & 4.11 & 4.72 & 7.35 \\
\hline 97 & $\begin{array}{l}\text { Air/Fan } \\
\text { Sprayer }\end{array}$ & 200.0 & 4.63 & $0: 14$ & 0.20 & 1.84 & 0.00 & 1.84 & 6.81 \\
\hline 97 & $\begin{array}{l}\text { Brush } \\
\text { Shredder } 6\end{array}$ & 250.0 & 1.90 & 0.06 & 0.08 & 1.19 & 0.00 & 1.19 & 3.24 \\
\hline 97 & $\begin{array}{l}\text { Disc - } \\
\text { Border }\end{array}$ & 199.4 & 1.20 & 0.04 & 0.05 & 0.46 & 0.00 & 0.46 & 1.74 \\
\hline 97 & $\begin{array}{l}\text { Disc - } \\
\text { Tandem } 7\end{array}$ & 200.0 & 1.55 & 0.05 & 0.07 & 0.59 & 0.00 & 0.59 & 2.25 \\
\hline 97 & $\begin{array}{l}\text { Drill Seeder } \\
5\end{array}$ & 120.0 & 1.67 & 0.05 & 0.07 & 0.49 & 0.00 & 0.49 & 2.28 \\
\hline 97 & Duster & 200.0 & 1.05 & 0.03 & 0.04 & 0.41 & 0.00 & 0.41 & 1.54 \\
\hline 97 & $\begin{array}{l}\text { Flat } \\
\text { Furrower }\end{array}$ & 199.6 & 0.62 & 0.02 & 0.03 & 0.23 & 0.00 & 0.23 & 0.90 \\
\hline 97 & $\begin{array}{l}\text { In-Row } \\
\text { Cultivator }\end{array}$ & 199.8 & 1.63 & 0.05 & 0.07 & 0.87 & 0.00 & 0.87 & 2.62 \\
\hline 97 & $\begin{array}{l}\text { Pick up }-1 / 2 \\
\text { ton }\end{array}$ & 285.0 & 5.18 & 0.17 & 0.24 & 1.18 & 2.80 & 3.98 & 9.56 \\
\hline 97 & $\begin{array}{l}\text { Shaker \& } \\
\text { Bin Dumper }\end{array}$ & 47.9 & 22.35 & 0.68 & 0.95 & 0.00 & 0.00 & 0.00 & 23.98 \\
\hline 97 & $\begin{array}{l}\text { Subsoiler - } \\
3 \text { Shank }\end{array}$ & 200.0 & 0.74 & 0.02 & 0.03 & 0.40 & 0.00 & 0.40 & 1.20 \\
\hline 97 & Terracer & 40.0 & 5.13 & 0.16 & 0.22 & 0.28 & 0.00 & 0.28 & 5.78 \\
\hline 97 & Trailer \#1 & 80.0 & 1.23 & 0.04 & 0.05 & 0.19 & 0.00 & 0.19 & 1.51 \\
\hline 97 & Trailer \#2 & 249.9 & 0.39 & 0.01 & 0.02 & 0.19 & 0.00 & 0.19 & 0.62 \\
\hline
\end{tabular}

*Actual hours used equals combined hours for raisins and other enterprises.

Return to Document

U.C. COOPERATIVE EXTENSION

Table 6. RANGING ANALYSIS FOR ORGANIC RAISIN GRAPE

PRODUCTION

SOUTHERN SAN JOAQUIN VALLEY - 1997

\section{COSTS PER ACRE AT VARYING YIELDS TO PRODUCE ORGANIC RAISIN GRAPES}




\begin{tabular}{|c|c|c|c|c|c|c|c|}
\hline & \multicolumn{7}{|c|}{ YIELD (TON/ACRE) } \\
\hline & 1.5 & 1.7 & 1.9 & 2.1 & 2.4 & 2.8 & 3.0 \\
\hline $\begin{array}{l}\text { OPERATING } \\
\text { COSTS/ACRE }\end{array}$ & & & & & & & \\
\hline Cultural Cost & 553 & 553 & 553 & 553 & 553 & 553 & 553 \\
\hline $\begin{array}{l}\text { Harvest \& } \\
\text { Assessment } \\
\text { Costs }\end{array}$ & 312 & 354 & 395 & 436 & 498 & 581 & 623 \\
\hline $\begin{array}{l}\text { Interest on } \\
\text { operating } \\
\text { capital }\end{array}$ & 28 & 28 & 28 & 28 & 28 & 28 & 28 \\
\hline $\begin{array}{l}\text { TOTAL } \\
\text { OPERATING } \\
\text { COSTS/ACRE }\end{array}$ & 893 & 934 & 976 & 1017 & 1079 & 1162 & 1203 \\
\hline $\begin{array}{l}\text { TOTAL } \\
\text { OPERATING } \\
\text { COSTS/TON }\end{array}$ & 595.38 & 549.66 & 513.56 & 484.34 & 449.64 & 414.95 & 401.07 \\
\hline $\begin{array}{l}\text { CASH } \\
\text { OVERHEAD } \\
\text { COSTS/ACRE }\end{array}$ & 248 & 248 & 248 & 248 & 248 & 248 & 248 \\
\hline $\begin{array}{l}\text { TOTAL } \\
\text { CASH } \\
\text { COSTS/ACRE }\end{array}$ & 1141 & 1182 & 1224 & 1265 & 1327 & 1410 & 1451 \\
\hline $\begin{array}{l}\text { TOTAL } \\
\text { CASH } \\
\text { COSTS/TON }\end{array}$ & 760.63 & 695.47 & 644.03 & 602.39 & 552.94 & 503.49 & 483.71 \\
\hline $\begin{array}{l}\text { NON-CASH } \\
\text { OVERHEAD } \\
\text { COSTS/ACRE }\end{array}$ & 848 & 848 & 848 & 848 & 849 & 849 & 849 \\
\hline $\begin{array}{l}\text { TOTAL } \\
\text { COSTS/ACRE }\end{array}$ & 1989 & 2031 & 2072 & 2113 & 2176 & 2259 & 2300 \\
\hline $\begin{array}{l}\text { TOTAL } \\
\text { COSTS/TON }\end{array}$ & 1326.10 & 1194.47 & 1090.55 & 1006.42 & 906.52 & 806.62 & 766.66 \\
\hline
\end{tabular}

NET RETURNS PER ACRE ABOVE OPERATING COSTS FOR ORGANIC RAISIN GRAPES

\begin{tabular}{|c||c|c|c|c|c|c|c||}
\hline $\begin{array}{c}\text { PRICE } \\
\text { (DOLLARS/TON) }\end{array}$ & \multicolumn{7}{|c||}{ YIELD (TON/ACRE) } \\
\hline \hline Raisins & 1.5 & 1.7 & $\mathbf{1 . 9}$ & $\mathbf{2 . 1}$ & $\mathbf{2 . 4}$ & $\mathbf{2 . 8}$ & $\mathbf{3 . 0}$ \\
\hline 950.00 & 532 & 681 & 829 & 978 & 1201 & 1498 & 1647 \\
\hline
\end{tabular}




\begin{tabular}{|c|c|c|c|c|c|c|c|}
\hline 1025.00 & 644 & 808 & 972 & 1135 & 1381 & 1708 & 1872 \\
\hline 1100.00 & 757 & 936 & 1114 & 1293 & 1561 & 1918 & 2097 \\
\hline 1175.00 & 869 & 1063 & 1257 & 1450 & 1741 & 2128 & 2322 \\
\hline 1250.00 & 982 & 1191 & 1399 & 1608 & 1921 & 2338 & 2547 \\
\hline 1300.00 & 1057 & 1276 & 1494 & 1713 & 2041 & 2478 & 2697 \\
\hline 1350.00 & 1132 & 1361 & 1589 & 1818 & 2161 & 2618 & 2847 \\
\hline
\end{tabular}

\section{NET RETURNS PER ACRE ABOVE CASH COSTS FOR ORGANIC RAISIN GRAPES}

$<$ td valign $=$ "top" width $=$

\begin{tabular}{|c|c|c|c|c|c|c|c|}
\hline PRICE & \multicolumn{5}{|c|}{ YIELD (TON/ACRE) } & \multicolumn{2}{|c|}{, } \\
\hline Raisins & 1.5 & 1.7 & 1.9 & 2.1 & 2.4 & 2.8 & 3.0 \\
\hline 950.00 & 284 & 433 & & & & & \\
\hline
\end{tabular}

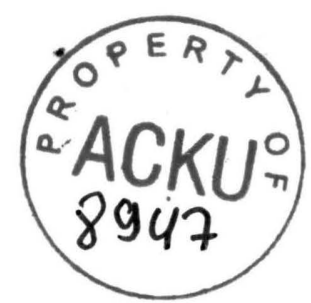

